\title{
Marketing Energy Conservation Options to Northwest Manufactured Home Buyers
}
P. L. Hendrickson
B. L. Mohler
Z. T. Taylor
A. D. Lee
S. A. Onisko

October 1985

Prepared for the Office of Conservation

Bonneville Power Administration under a Related Services Agreement with the U.S. Department of Energy Contract DE-AC06-76RLO 1830

Pacific Northwest Laboratory Operated for the U.S. Department of Energy by Battelle Memorial Institute 


\title{
DISCLAIMER
}

This report was prepared as an account of work sponsored by an agency of the United States Government. Neither the United States Government nor any agency thereof, nor any of their employees, makes any warranty, express or implied, or assumes any legal liability or responsibility for the accuracy, completeness, or usefulness of any information, apparatus, product, or process disclosed, or represents that its use would not infringe privately owned rights. Reference herein to any specific commercial product, process, or service by trade name, trademark, manufacturer, or otherwise, does not necessarily constitute or imply its endorsement, recommendation, or favoring by the United States Government or any agency thereof. The views and opinions of authors expressed herein do not necessarily state or reflect those of the United States Government or any agency thereof.

\author{
PACIFIC NORTHWEST LABORATORY \\ operated by \\ BATTELLE \\ for the \\ UNITED STATES DEPARTMENT OF ENERGY \\ under Contract DE-AC06-76RLO 1830
}

\begin{tabular}{|c|c|}
\hline \multicolumn{2}{|c|}{ Printed in the United States of America } \\
\hline \multicolumn{2}{|c|}{ Available from } \\
\hline \multirow{2}{*}{\multicolumn{2}{|c|}{$\begin{array}{l}\text { National Technical Information Service } \\
\text { United States Department of Commerce }\end{array}$}} \\
\hline & \\
\hline \multicolumn{2}{|c|}{5285 Port Royal Road } \\
\hline \multicolumn{2}{|c|}{ Springfield, Virginia 22161} \\
\hline \multicolumn{2}{|c|}{ NTIS Price Codes } \\
\hline \multicolumn{2}{|c|}{ Microfiche A01 } \\
\hline \multicolumn{2}{|c|}{ Printed Copy } \\
\hline & Price \\
\hline Pages & Codes \\
\hline $001-025$ & $\mathrm{~A} 02$ \\
\hline $026-050$ & $\mathrm{~A} 03$ \\
\hline $051-075$ & A04 \\
\hline $076-100$ & $\mathrm{~A} 05$ \\
\hline $101-125$ & A06 \\
\hline $126-150$ & $\mathrm{~A} 07$ \\
\hline 151.175 & $\mathrm{~A} 0 \mathrm{~B}$ \\
\hline $176-200$ & $\mathrm{~A} 09$ \\
\hline $201-225$ & A010 \\
\hline $226-250$ & A011 \\
\hline $251-275$ & $\mathrm{~A} 012$ \\
\hline $276-300$ & $\mathrm{~A} 013$ \\
\hline
\end{tabular}


MARKETING ENERGY CONSERVATION OPTIONS

TO NORTHWEST MANUFACTURED HOME BUYERS

P. L. Hendrickson

B. L. Mohler

Z. T. Taylor

A. D. Lee

S. A. Onisko(a)

September 1985

Prepared for the Office of Conservation Ronneville Power Administration under a Related Services Agreement with the U.S. Department of Energy under Contract BE-AC06-76RLO 1830

Pacific Northwest Laboratory

Richland, Washington 99352

(a) Bonneville Power Administration, Port land Oregon 



\section{FOREWORD}

This report, PNL-5496-Rev 1, is being published and distributed as an updated revision of the original report PNL-5496, published June 1985. It contains several statistics that have become available since publication of the original report and incorporates editorial changes and corrections. Copies of the original report should be replaced with this version. 
SUMAMARY

Manufactured, or HUD-Code, homes comprise a growing share of the housing stock in the Northwest (see definition on page 8.1 ), as well as nationally. Their relatively low cost has made them especially attractive to lower income families, first-time home-buyers, and retired persons. Unitke conventional site-built homes, manufactured homes must conform to regulations established by the U.S. Department of Housing and Urban Development (HUD) but need not meet local building codes. The characteristics of manufactured home (MH) buyers, the unique energy consumption characteristics of the homes, and their increasing market share make this market an especially critical one for energy consumption and conservation planning in the Northwest.

Pacific Northwest Laboratory (PNL), operated by the Battelle Memorial Institute for the J.S. Department of Energy (DOE), conducted this study for the Bonneville Power Administration's (BPA) Office of Conservation. This study supports BPA's programmatic activities to acquire electric power resources through conservation as required by the Pacific Northwest Electric Power Planning and Conservation Act (the "Act"). The Act specifically required development of regional model conservation standards (MCS) for new buildings. The likelihood that the preemptive HUD regulations would exempt manufactured homes from coverage by the MCS, and the significant and increasing role manufactured housing is playing in the Northwest has prompted BPA to investigate alternative means of achieving conservation in this growing housing sector.

This study relies on extensive, existing survey data and new ana?yses to develop information that can potentially assist the design of a marketing plan to achieve energy conservation in new manufactured homes. This study has the objective of assisting BPA in the development of a regional approach in which numerous organizations and parties would participate to achieve conservation in new manufactured homes.

Existing surveys present comprehensive information about regional manufactured home occupants and their homes that are relevant to a potential conservation marketing plan. Important differences exist between manufactured and site-built homes and between their occupants; Northwest regional 
characteristics also differ in important ways from national characteristics. Nearly one-half of Northwest manufactured homes are located in the high heating load areas east of the Cascades, compared to about one-third of site-built homes. Similarly, nearly two-thirds of manufactured homes are in rural locations, whereas only about $40 \%$ of site-built homes are in rural areas. While manufactured homes constitute about $10 \%$ of the region's single-famity housing stock, they constituted over $25 \%$ of additions to the same stock in 1984. Over half the manufactured homes being sold in the Northwest are doublesection homes, whereas the national figure is closer to $20 \%$; double-section homes are likely to cost more and consume more energy than single-section homes. Manufactured homes in the Northwest are more likely to have electric space heating than site-built homes, but both housing types have shown a trend toward increasing utilization of wood for space heating. About two-thirds of Northwest manufactured home occupants have no college education, whereas only about $45 \%$ of site-built home occupants have none. Also, manufactured home households typically have incomes below those of site-built households. And finally, Northwest manufactured home occupants tend to be below 35 or over 55 more often than site-built home occupants.

A previous survey and information collected for this study from regional dealers and manufacturers provide an indication of the energy conservation options being sold to manufactured home buyers in the PNW. Manufacturers in the Northwest appear to sell homes that usually exceed the HUD thermal requirements. Manufacturers typically offer efficiency improvements in packages that include fixed improvements in insulation levels, glazing, and infiltration control. Wholesale costs of these packages range from about $\$ 100$ to $\$ 1500$. Typical packages include significant upgrades in floor insulation values with modest upgrades in ceilings and walls.

An independent analysis presented in this study of the cost-effectiveness of various efficiency improvements provides background information for designing a marketing plan. This analysis focuses on the economic impacts of afternative energy conservation options as perceived by the home owner. It identifies trends and impacts that a marketing plan should consider to adequately address the financial concerns of manufactured home buyers. The 
analysis uses life cycle cost as the basic economic evaluation format, specifically the change in life cycle cost as a result of implementing various conservation options. This net life cycle cost quantifies the economic effects of an investment decision by accounting for all future costs and benefits, the consumer's discount rate, and tax deductions. Most consumers, however, are either unfamiliar with this analysis approach or have doubts about the validity of estimates projected more than a few years into the future. Recognizing these shortcomings, this analysis also considers payback periods and cash flow. Using minimum net life cycle costs (maximum life cycle savings), this study provides information about the optimum conservation options for each of the MCS climate zones and for single- and double-section manufactured homes. For example, the analysis indicates that in Kalispel] for single-section homes the most cost-effective package would have $R-30$ ceiling insulation, $R-24$ wall insulation, and R-22 floor insulation as compared to a minimum base case package of $R_{-11}, R_{-} 7, R_{-7}$, respectively. The results indicate that the life-cyclecost based optimum design package produces simple paybacks within about 8 years for all climate zones and for both manufactured home sizes. Also, all optimum packages produce positive cash flows within two years. Colder climates lead to larger net savings as do double-section homes when compared to single-section homes. Floor insulation upgrades appear to be the best investment choice if expenditures are limited. Significantly, the life cycle cost curves tend to be very flat for conservation levels tighter than the optimum, so additional conservation could be achieved in these homes for life cycle costs near the minimum. Assumed discount rate levels tend to affect the results much more than assumed tax bracket rates. These results suggest that considerable costeffective conservation potential exists for manufactured homes in the region and it could be achieved with relatively favorable short-term econonic effects. The results also reveal the most economic options and should help target marketing efforts.

Identifying impediments to conservation investments is also very important in designing a marketing plan. A recent report suggests that financial constraints and the need for better information and knowledge about conservation pose the major conservation investment barriers. Since loan interest rates for new manufactured homes typically exceed rates for site-built homes by a 
considerable amount and their buyers tend to have lower incomes, the economics of manufactured home conservation investments are likely to significantly influence their viability. Conservation information and its presentation directly influences the manufactured home buyer's decision. Regional residents tend to view information from local utilities as more believable than information from building contractors, BPA, and state energy offices. A marketing plan should address these two impediments and their implications yery clearly.

Both Northwest and national survey data provide insights into manufactured home owner and dealer attitudes toward energy conservation options. Such data are important in determining what marketing appeals may be most effective and what targeting may be necessary. Manufactured home owners typically believe that efficiency improvements are very feasible through either one-time actions or 1 ifestyle changes that are worth engaging in to reduce utility bills. Mational data suggest manufactured home owners intend to buy higher insulation leveis in their next home and in the Northwest they view the first cost for energy conservation as less important than future energy savings. Manufactured home owners, however, prefer making lifestyle or behaviorai changes over conservation investments. They also tend to be homebodies and doubt that there is a current energy supply problem. Advertising appears to play a very sma11 role in the consumer decision to buy a manufactured home. These data suggest that a suitable conservation marketing program would have a receptive audience, but one which has characteristics that must be clearly defined and addressed to make the program a success.

Survey data of dealers present an informative comparison between dealer and buyer attitudes. For example, dealers tend to estimate buyer interest in energy conservation features at a lower level than buyers themselves indicate. Furthermore, dealers tend to underestimate consistently the amount their buyers indicate they would be willing to pay for conservation options. Dealers do express a belief that consumer satisfaction is the major advantage to selling energy efficient manufactured homes. This information suggests that targeting dealers in a marketing plan and providing them direct information on consumers' indicated attitudes may be important. 
Using the information gathered in this project and basic marketing theory, this report describes the desirable features of a possible marketing program. Goals for marketing plans can address four types of changes: cognitive changes, action changes, behavioral changes, and value changes. The changes are listed in the order of difficulty of achievement. Cognitive changes (e.g., increased awareness of conservation approaches), action changes (e.g., purchase of an efficiency package in a new home), and behavior changes (e.g., setting back thermostats at night) are more realistic to achieve and should receive most attention. For a program in which BPA plays a major role to promote energy conservation in new manufactured homes, the plan should include the following components: clear statement of the problem; establishment of goals; segmentation of the target market; analys is of targeted consumer group characteristics; determination of which market and non-market players affect the consumer decision and how; marketing strategy development; implementation; and monitoring and control. Infivence channels are especially important to identify and understand because the manufactured housing market involves many players directly and indirectly. For example, utilities, park owners, and trade associations all influence the direct market participants-manufacturers, dealers, and consumers. Numerous other marketing proyrams for energy conserving manufactured homes have been conducted by utilities, states, and equipment manufacturers. This report discusses these programs and discusses the lessons learned from these experiences. Along with actual experiences, marketing theory helps focus future marketing programs through models of the consumer decision process. It is essential early in the planning process to decide where in the decision process to focus the program. The program would probably utilize a blend of four elements--sales promotion, personal selling efforts, publicity, and advertising. The mix of these elements will depend on the nature of the consumers and the decision process focus. The budget and costeffectiveness must be determined and will play a key role in shaping the program.

This study does not provide or develop a marketing program, but does provide the initial background information and a framework necessary to begin this process. Targeting based on consumer characteristics should be a major consideration. Dealers appear to play a significant role in consumer decision 
making and should be provided more information about their consumers' views and should be included in a marketing program. Finally, available information suggests that the manufactured home sector represents a significant and unique target for energy conservation marketing and, through a well-designed program, could provide energy savings not likely to occur otherwise, while benefiting the occupants of nearly one third of new single-family housing. 


\section{CONTENTS}

FOREWORD

i i i

SUMPARY

$\checkmark$

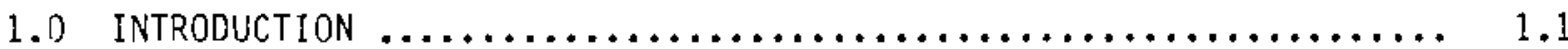

REFERENCES AND NOTES FOR SECTION $1.0 \ldots \ldots \ldots \ldots \ldots \ldots \ldots \ldots \ldots \ldots \ldots \ldots \ldots \ldots \ldots$

2.0 ROLE OF MANUFACTURED HOUSING IN THE NORTHWEST HOUSING MARKET $\ldots . .2 .1$

2.1 LOCATION AND OCCUPANCY DATA $\ldots \ldots \ldots \ldots \ldots \ldots \ldots \ldots \ldots \ldots \ldots \ldots \ldots \ldots \ldots \ldots \ldots$

2.2 SALES AND PRODUCTION DATA $\ldots \ldots \ldots \ldots \ldots \ldots \ldots \ldots \ldots \ldots \ldots \ldots \ldots \ldots \ldots$

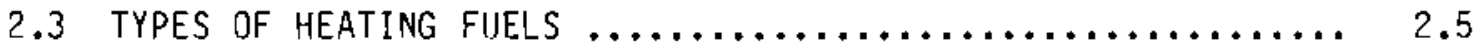

2.4 CHARACTERISTICS OF MANUFACTURED HOME OCCUPANTS $\ldots \ldots \ldots \ldots \ldots ? .8$

REFCRENCES AND NOTES FOR SECTION $2.0 \ldots \ldots \ldots \ldots \ldots \ldots \ldots \ldots \ldots \ldots \ldots \ldots \ldots \ldots \ldots$

3.9 MANUFACTURED HOME ENERGY CONSERVATION OPTIONS AVAILABLE

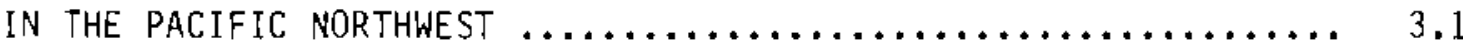

3.1 MHI SURVEY OF THERMAL OPTIONS OFFERED BY MANUFACTURED

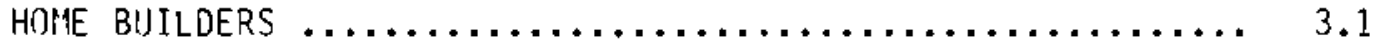

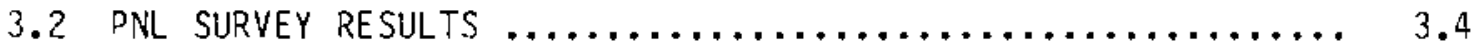

REFERENCES AND NOTES FOR SECTION $3.0 \ldots \ldots \ldots \ldots \ldots \ldots \ldots \ldots \ldots \ldots \ldots \ldots \ldots \ldots \ldots$

4.0 COST AND PERFORMANCE OF ENERGY SAVING OPTIONS $\ldots \ldots \ldots \ldots \ldots \ldots \ldots . . .$.

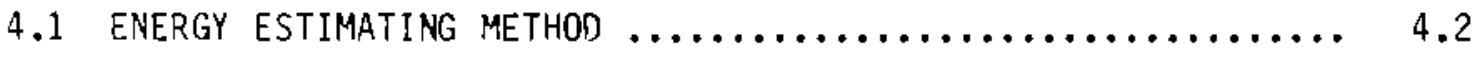

4.2 CONSERVATION OPTION COST SOURCES .................. 4.4

4.3 ECONOMIC EVALUATION METHODOLOGY ANO CRITERIA $\ldots \ldots \ldots \ldots \ldots \ldots .4 .5$

4.3.1 Establishment of a Baseline for Comparison of Options ............................. 4.5

4.3 .2 Economic Criteria ..................... 4.6

4.3.3 Relevance of the Economic Criteria to Marketing

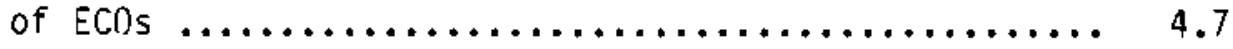

4.4 ECONOMIC PARAMETERS CHOSEN FOR THE COMPARISONS $\ldots \ldots \ldots \ldots \ldots .4 .8$ 
4.4.1 Assumptions Regarding the Home Mortgage .......... 4.9

4.4.2 Assumptions Regarding Discount and Tax Rates ....... 4.9

4.4.3 Assumptions Regarding Fuel Prices and Equipment Efficiencies

4.5 COMPARISON OF ECONOMIC PERFORMANCE OF ENVELOPE OPTIONS $\ldots . . .4 .10$

4.5.1 Preferred Envelope Combinations ............... 4.11

4.5.2 Ranking of the Envelope Options by Economic Effectiveness ......................... 4.11

4.5 .3 Sensitivity of Economic Inputs $\ldots \ldots \ldots \ldots \ldots \ldots \ldots . . \ldots \ldots$

4.5 .4 Summary and Conclusions $\ldots \ldots \ldots \ldots \ldots \ldots \ldots \ldots \ldots . \ldots . \ldots . . \ldots$

REFERENCES AND NOTES FOR SECTION $4.0 \ldots \ldots \ldots \ldots \ldots \ldots \ldots \ldots \ldots \ldots \ldots \ldots . . \ldots . \ldots 22$

5.0 BARRIERS TO INVESTMENT IN EXTRA COST ENERGY

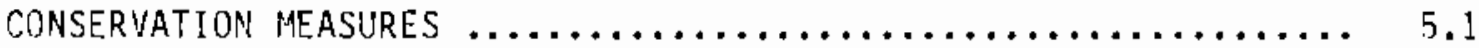

5.1 FINANCIAL BARRIERS $\ldots \ldots \ldots \ldots \ldots \ldots \ldots \ldots \ldots \ldots \ldots \ldots \ldots \ldots \ldots \ldots \ldots \ldots \ldots \ldots$

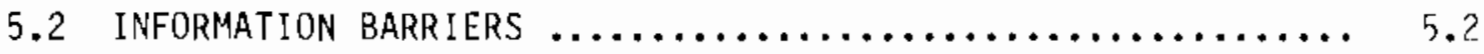

REFERENCES AND NOTES FOR SECTION $5.0 \ldots \ldots \ldots \ldots \ldots \ldots \ldots \ldots \ldots \ldots \ldots \ldots \ldots \ldots \ldots \ldots \ldots$

6.0 REVIEW OF SURVEY DATA CONCERNING MANUFACTURED HOHE RESIDENT

AND DEALER ATTITUDES TOWARD ENERGY EFFICIENCY OPTIONS ........ 6.1

6.1 OBSERVATIONS ORAWN FROM HOME AND OPTIONS SALES SURVEY

DATA

6.1.1 The Facts on the Future and How They Stack Up: A Study of Owner Attitudes Toward Manufactured

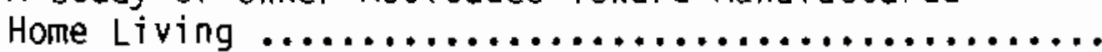

6.1.2 Observations Concerning MH Consumer Attitudes Toward ECO Purchase

6.2 OBSERVATIONS FROM EXISTING CONSUMER ATTITUOE SURVEY DATA $\ldots \quad 6.6$

6.2.1 Manufactured Homes: The Market Facts, Important Answers from Owners of Manufactured Homes About Themselves and Their Homes

6.2.2 Barriers to Greater Sales Growth, An Investigation of Consumer Shelter Decision-Maxing as It Impacts the lobile Home Industry 
6.2.3 Facts on the Future and How They Stack Up: A Study of Owner Attitudes Toward Manufactured Home Living ............................ 6.11

6.2.4 Pacific Northwest Residential Energy Survey ....... 6.14

6.2.5 The Marketing Environment for Energy Conservation in the Pacific Northwest ..................... 6.20

6.2.6 Sumnary of Consumer Attitude Data ............ 6.25

6.3 DEALER/RETAILER ATTITUDE SURVEY DATA $\ldots \ldots \ldots \ldots \ldots \ldots \ldots \ldots .6 .28$

6.3.1 Dealer and Consumer Attitudes Toward Energy Efficiency ............................. 6.28

6.3.2 Discussion of the Dealers' Role in the Purchase Decision Process ........................... 6.32

REFERENCES AND NOTES FOR SECTION $6.0 \ldots \ldots \ldots \ldots \ldots \ldots \ldots \ldots \ldots \ldots \ldots \ldots \ldots \ldots$

7.0 DESIRABLE FEATURES OF A MARKETING PROGRAM TO PROMOTE ENERGY-

EFFICIENT NEW MANUFACTURED HOMES $\ldots \ldots \ldots \ldots \ldots \ldots \ldots \ldots \ldots \ldots \ldots \ldots \ldots \ldots \ldots \ldots$

7.1 THE gENERIC STRUCTURE DF A MARXETING PLAN ............ 7.1

7.2 INFLUENCE CHANNELS AND THEIR POSSIBLE IMPORTANCE

TO A MARKETING PROGRAM ....................... 7.9

7.3 "LESSONS LEARNED" FROM OTHERS' EXPERIENCE WITH MARXETING PROGRAMS FOR ENERGY-EFFICIENT MANUIFACTURED HOMES $\ldots \ldots \ldots \ldots .7 .18$

7.3.1 Duke Power Company "Residential Conservation" Rate

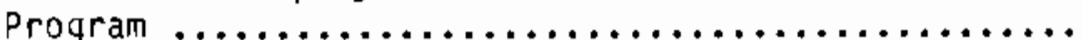

7.3.2 Arkansas Power and Light's Energy Saver Award Program ................................. 7.20

7.3.3 Owens-Corning Fiberglas Corp.'s Energy-Qualified Home Program ........................... 7.21

7.3.4 State of Maine "Energy Efficient Manufactured home Program" ........................... 7.22

7.3 .5 Wick Building Systems, Inc. ................. 7.24

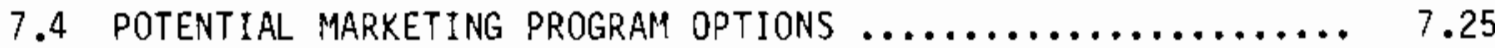

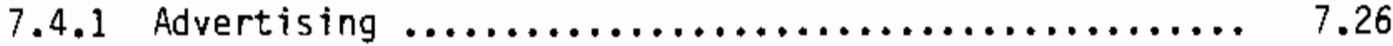

7.4.2 Electricity Rate Incentives $\ldots \ldots \ldots \ldots \ldots \ldots \ldots \ldots \ldots . . \ldots .27$ 


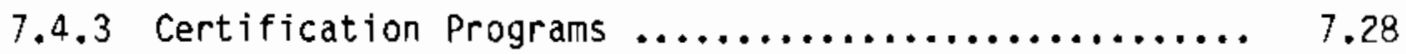

7.4.4 Informational and Educational Programs .......... 7.28

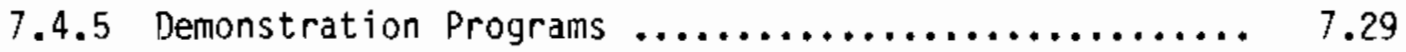

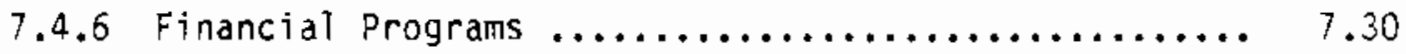

7.4.7 Siting Programs $\ldots \ldots \ldots \ldots \ldots \ldots \ldots \ldots \ldots \ldots, 7.30$

7.4.8 An Integrated Marketing Program Designed by

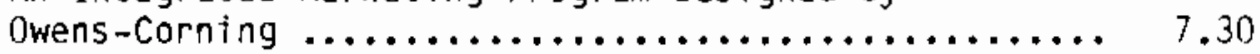

7.5 DESIRABLE FEATURES OF A MARKETING PROGRAM $\ldots \ldots \ldots \ldots \ldots \ldots, 7.31$

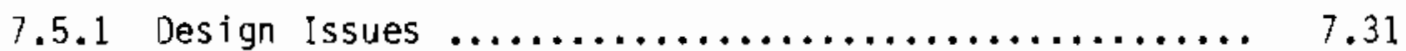

7.5 .2 Cost-Effectiveness $\ldots \ldots \ldots \ldots \ldots \ldots \ldots \ldots \ldots \ldots \ldots, \quad 7.33$

7.5 .3 Implementation $\ldots \ldots \ldots \ldots \ldots \ldots \ldots \ldots \ldots \ldots \ldots \ldots \ldots, \quad 7.35$

7.5 .4 Control $\ldots \ldots \ldots \ldots \ldots \ldots \ldots \ldots \ldots \ldots \ldots \ldots \ldots \ldots \ldots \ldots \ldots \ldots, 7.35$

7.5.5 Preliminary Marketing Program Suggestions ......... 7.35

7.5 .6 Conclusions $\ldots \ldots \ldots \ldots \ldots \ldots \ldots \ldots \ldots \ldots \ldots \ldots \ldots \ldots \ldots, 7.37$

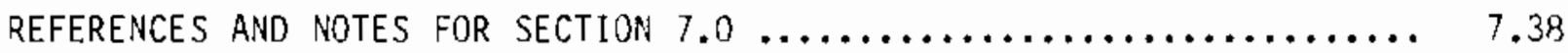

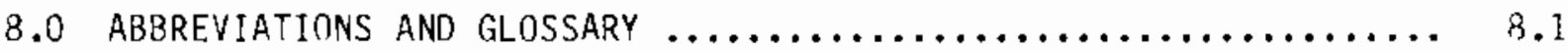

APPENDIX A - EXISTING PROGRAMS TO ENCOURAGE ENERGY CONSERVATION IN

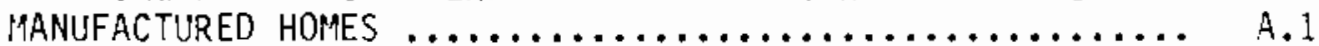

APPENDIX B - MANUFACTURERS WHO SELL hOMES IN THE NORTHWEST $\ldots \ldots \ldots \ldots$ B. 1

APPENDIX C - NORTHWEST MANUFACTURED HOUSING TRADE ASSOCIATIONS $\ldots \ldots \ldots c .1$

APPENDIX D - COVERLETTER AND SAMPLE RESPONSE FORM USED TO COLLECT HOME AND OPTIONS SALES DATA FROM NORTHWEST MANIJFACTURERS

D.1

APPENDIX E - INDOOR AIR QUALITY IN MANUFACTURED HOMES $\ldots \ldots \ldots \ldots \ldots$ E. 


\section{FIGURES}

4.1 Change in Life Cycle Cost Due to Purchase of Insulation Upgrades - Portland ................................ 4.13

4.2 Change in Life Cycle Cost Due to Purchase of Insulation Upgrades - Spokane ................................ 4.14

4.3 Change in Life Cycle Cost Due to Purchase of Insulation Upgrades - Kalispel1 ............................. 4.15

4.4 Change in Life Cycle Cost Due to Purchase of Window Upgrades ... 4.16

7.1 Three Levels of Marketing Plan Development .............. 7.10

7.2 Consumer Decision Participant Channels ................. 7.11

7.3 The Relative Merits of Alternative Promotional Mix Activities ... $\quad 7.34$ 


\section{TABLES}

2.1 Numbers and Location of Housing Units $\ldots \ldots \ldots \ldots \ldots \ldots \ldots \ldots . . . \ldots$

2.2 1983 Location of Northwest Manufactured and Other Single Family Detached Homes ................................. 2.3

2.31980 Occupancy Status of Living Units $\ldots \ldots \ldots \ldots \ldots \ldots \ldots \ldots \ldots . . . \ldots$

2.41983 Occupancy Status of Living Units $\ldots \ldots \ldots \ldots \ldots \ldots \ldots \ldots \ldots$

2.5 New MHs Placed for Residential IJse in $1984 \ldots \ldots \ldots \ldots \ldots \ldots \ldots . . \ldots$

2.61984 Housing Starts $\ldots \ldots \ldots \ldots \ldots \ldots \ldots \ldots \ldots \ldots \ldots \ldots \ldots \ldots \ldots \ldots$

2.7 Northwest Manufactured Home Production Figures $\ldots \ldots \ldots \ldots \ldots \ldots \ldots$

2.8 Primary Space Heating Fuel of Existing Northwest Single Family

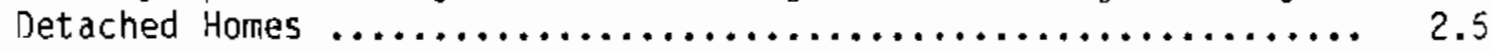

2.9 Primary Space Heating Fuel by MH Age Category $\ldots \ldots \ldots \ldots \ldots \ldots . . . . .$.

2.10 Primary Water Heating Fuel $\ldots \ldots \ldots \ldots \ldots \ldots \ldots \ldots \ldots \ldots \ldots \ldots \ldots$

2.11 Age of Adult Northwest Single Family Detached Home Occupants .... 2.9

2.12 Education Level of Adult Northwest Single Family Detached Home Occupants ................................ 2.9

?.13 Before Tax Household Income of Northwest Single Family Detached Home Dccupants ................................. 2.9

3.1 Typical Option Availability and Cost from PNL Letter Survey .... 3.5

4.1 Envelope Conservation Features Available in the Energy Data Base ........................................ 4.3

4.2 Northwest Cities Included in ECD Cost/Performance Analyses ..... 4.4

4.3 Comparison of Cost Data Base with Actual Prices ............ 4.5

4.4 Economic Parameters Used in Life Cycle Cost Comparisons ....... 4.8

4.5 Current Electricity Prices in the Northwest $\ldots \ldots \ldots \ldots \ldots \ldots \ldots \ldots . . \ldots$

4.6 Real Electricity Price Escalation Rates .................. 4.10

4.7 Preferred Packages Based on Minimum Life Cycle Cost ......... 4.11 
4.8 Payback Period, First Year Cash Flow, and Year in Which Cash Flow Becomes Positive of Optimum Packages Based on Minimum Life Cycle Cost ................................... 4.12

4.9 Economic Parameters Used in Sensitivity Comparisons ......... 4.18

4.10 Preferred Envelope Packages For Various Economic Scenarios ..... 4.19

4.11 Payback Period, First Year Cash Flow, and Year in which Cash Flow Becomes Positive of Optimum Packages Based on Minimum

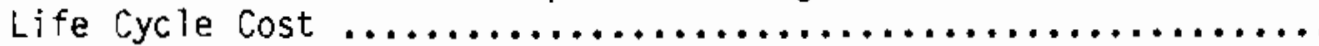

6.1 Probability of Future Option Purchase in Next Manufactured Home; National Data ............................. 6.2

6.2 Probability of Buying More Insulation in Next Manufactured Home Purchased by Owens-Corning Fiberglas Regions ............... 6.3

6.3 Probability of Buying More Insulation in Next Manufactured Home by Price and Width of Current Home; National Data ........... 5.3

6.4 Satisfaction Levels with Selected Attributes and Options of

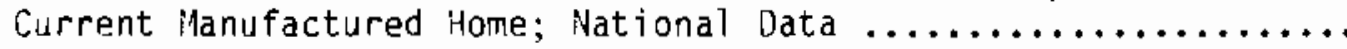

6.5 Home Selected from Inventory or Ordered; National Data ....... 5.4

6.6 Number of MH Brands Considered and Dealers Shopped; National Data

6.7 Information Source Consumers lised to Locate Dealers; Nationa? Data

6.8 ilanufactured Home Size; National Data $\ldots \ldots \ldots \ldots \ldots \ldots \ldots \ldots \ldots .6 .6$

6.9 Location of Manufactured Home as Sited; National Data ......... 6.6

6.10 Perceived Construction Quality of Manufactured Homes Today Versus Five Years Ago; National Data .................... 6.7

6.11 Major Advantages of Living in a Manufactured Home as Perceived

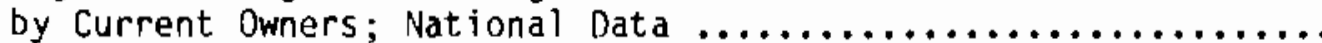

6.12 Satisfaction with Manufactured Home Living in General;

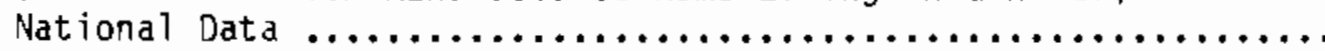

6.13 Average Importance Ratings by Groups of Energy Efficiency Considerations; National Data

6.14 Perceptions of Energy Efficiency in Manufactured Homes; National Data. 
6.15 Psychographic Segmentation of Residence Owner Types;

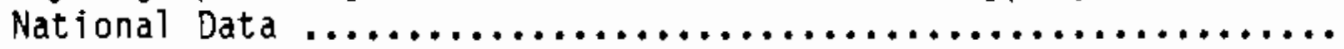

6.16 Overall Satisfaction with Manufactured Home Living;

National Data

6.17 Planned Tenure in Current Manufactured Home; National Data ......

6.18 Why Mobile Home Living is Chosen; National Data

6.19 Manufactured Home Occupants Attitudes Toward Energy Cost

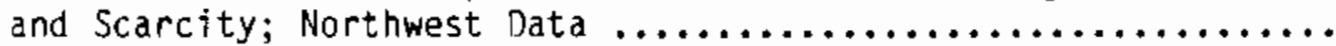

5.20 Price-Conservation Relationship Attitudes; Northwest Jata .......

6.21 To Conserve Enough Energy to Make a Difference in My Bills, I Would Have to Change My Lifestyle; Northwest Data ............

6.22 Attitudes Toward Specific Energy Saving Behaviors; Northwest Data

6.23 Comfort Level by Age of $\mathrm{MH}$; Horthwest Data

6.24 Ease of Retrofit by MH Age; Northwest Data

6.25 Lifestyle Changes and Energy Savings by Age of $\mathrm{M} 1 \mathrm{H}$; Horthwest

6.26 Energy Efficiency by ilH Age

6.27 Perceived Seriousness of the Energy Situation; Northwest

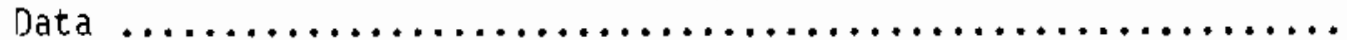

6.28 Respondent Choice to Reduce Energy Use; Northwest Data $\ldots \ldots \ldots .6 .22$

6.29 Consumer Segmentation by Attitude Toward Energy Conservation; Northwest Data

6.30 Resident Classification into Prospect Target Groups;

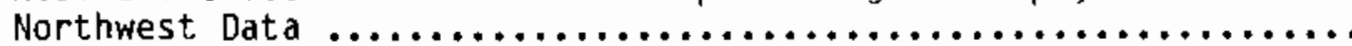

6.31 Intentions to Perform Future Improvements to Save Energy; Northwest Data

6.32 Perceived Images of Energy Institutions

6.33 Consumer/Dealer Interest in Energy-Efficient Homes..........

6.34 Interest Intensity in Energy Efficient Manufactured Homes ....... 
6.36 Amount Consumers are Willing to Spend for Energy Efficiency .... 6.30

6.37 Interest in Specific Energy Features $\ldots \ldots \ldots \ldots \ldots \ldots \ldots \ldots \ldots \ldots . \ldots \ldots$

6.38 Dealer Perceived Advantages to Selling Energy-Efficient MHs .... 6.31

6.39 Incidence of Energy-Efficient Manufactured Home Purchase Among Buyers Who Received Energy-Efficient Options Promotions by

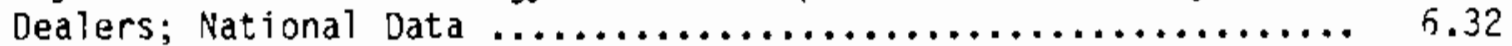

6.40 Incidence of Dealer Promotion of Energy-Efficient Manufactured Homes; National Data ............................. 6.32

7.1 Northwest Manufactured Home Association Membership .......... 7.17 


\subsection{INTRODUCTION}

The principal objectives of this study are to 1) identify the availability and price of energy conservation options for manufactured homes in the Northwest, 2) examine barriers and incentives for purchase of these options, and 3) identify desirable features of a marketing plan to enhance the sale of options to improve the energy efficiency of new manufactured homes. The work is being prepared for the office of Conservation, Bonneville Power Administration (BPA).

BPA is interested in manufactured home energy conservation as part of its broader activities to encourage energy conservation and acquire conservation resources in the Northwest. BPA's programnatic interest in the area of energy conservation was enhanced by Congressional passage of the Pacific Northwest Electric Power Planning and Conservation Act (the "Act") in 1980. (1) The Act established the Northwest Power Planning Council(2) (the "Council") and required the Council to prepare and issue a regional conservation and electric power plan (the "olan").(3) The Plan was subsequently issued in April 1983. (4) A revised draft of the Plan is scheduled for release in August, 1985. Under the Act, BPA is to acquire electric power resources through conservation and otherwise, consistent with the Plan. (5) The Act places the highest priority on the acquisition of conservation resources. (6) Additionally, BPA is to naxe the maximum practicable use of its customers and local entities in implementing conservation programs that require direct arrangements with retai 1 consumers. (7)

The Act required the Council to prepare model conservation standards (MCS) for new buildings. (8) These standards appear in Appendix $J$ of the 1983 Plan. The 1983 Plan requests northwest regional state governments (Idaho, Montana, Oregon, and Washington), local governments, or utilities to adopt and enforce the model standards by January 1 , 1986. (9) Utilities that serve geographic areas that are not implementing the model standards are potentially subject to a surcharge on power purchased from BPA and consumed in these areas. (10)

The focus of this report is on manufactured housing; specifically, manufactured homes constructed according to the llanufactured Home Construction and 
Safety Standards (MHCSS) issued by the U.S. Department of Housing and Irban Development (HUD).(11) Homes built to these standards are often called "mobile homes" by the public, and are sometimes referred to as "Hun-code homes" by those in the industry. This report will follow the practice in the HuD standards and use the term "manufactured housing."(12) It should he kept in mind throughout the report that the term "manufactured housing" refers to homes built to the HIJD MHCSS and not to the other categories of manufactured homes, i.e., modular/sectional, panalized, and pre-cut homes. These latter three categories of homes, while technically "manufactured homes," are built to comply with state and local building codes rather than the HIIP construction standards.

A special reason for BPA interest in manufactured homes beyond its programmatic conservation interest under the Regional Power Act is that it is very unlikely that the Council's model conservation standards can be applied to manufactured homes. (13) The National lanufactured Housing Construction and Safety Standards Act of 1974 provides that no state or local government shall have authority to establish "any standard regarding construction or safety applicabie to the same aspect, of performance of such manufactured home which is not identical to the Federal manufactured home construction and safoty standard."(14) The Hun construction standards for manufactured homes include thermal performance standards at 24 C.F.R. 3280 Subpart F. 3ased on the ahove quoted language in the 1974 Act, it seems unlikely that the much stricter thermal performance standards in the MCS can he applied to Northwest manufactured homes.

In August 1983, HUD proposed a regulation that would require manufacturers to offer improved energy efficiency as an option to consumers. (15) The proposed regulation is still pending. Even if adopted, the option that would be required to he offered to consumers will offer thermal performance well below the MCS.

BPA is also interested in the potential application of the "Super Good Cents" program to manufactured housing. This program was initiated in nctober 1984 by BPA and participating BPA utility customers. (16) Homes built to the MCS are eligible for a Super Good Cents certification. Participating utilities 
review construction plans and inspect the home during construction. Completed homes that meet the MCS are certified and can he marketed as Super Good Cents homes. BPA is supporting the program with advertising and marketing assistance. 
1. Public law 96-501, enacted necember 5, 1980.

2. 16 U.S.C.A. $839 b(a)(2)$. Section $4 .(a)(2)$ of the Act.

3. 16 U.S.C.A. 839h(d). Section 4.(d) of the Act.

4. Northwest Power Planning Counci1, Portland, Dregon, Northwest Conservation and Electric Power Plan, Vol. 1 and 2, April 27, 1983.

5. 16 tJ.S.C.A. $839(d)(b)(1)$. Section $6 .(b)(1)$ of the Act.

6. 16 II.S.C.A. $839(b)(e)(1)$. Section $4 .(3)$ of the Act.

7. 16 13.S.C.A. 839d(e)(2). Section $6 .(e)(2)$ of the Act.

8. 16 U.S.C.A. 839b(f). Section 4.(f) of the Act.

9. Action item 2.1 in Chapter 10 of the Plan requests implementation for rosidential buildings; action item 6.1 requests implementation for commercial builitings.

10. 16 II.S.C.A. $939 h(f)$. Section 4.(f) of the Act.

11. The standards hecame effective in 197h. They were issued pursuant to a directive in the National "anufactured Housing Construction and Safety Standards Act of 1974 (42 H.S.C.A. 54n3). The standards appear at ?.4 C.F.R. 32Rn.

12. HIIn tefines a manufactured home at 2.4 C.F.R. 3?8n.?(16) as a "structure, transportable in one or more sections, which in the traveling mode, is eight hody feet or nore in width or forty hody feet or more in length, or, when erected on site, is three hundred twenty or more square feet, and which is built on a permanent chassis and designed to be used as a dwelling with or without a permanent foundation when connected to the required utilities, and includes the plumbing, heating, air-conditioning and electrical systems contained therein."

13. The Council staff have stated that "neither the Council, states or local governments have the ability to mandate energy efficiency standards for (manufactured) homes." "1985 Action Plan Issue Paper: Conservation Resources," May 8, 1985.

14. 42 U.S.C.A. 5403(d).

15. 48 Federal Register 37173, August 16, 1983.

16. BPA Issue Alert, "BPA Launches Super food Cents," DOE/BP-325, Dctober 1984. 


\subsection{ROLE OF MANUFACTURED HOUSING IN THE NORTHWEST HOUSING PARKET}

The purpose of this section is to provide background information on the role of manufactured housing in the Northwest housing market. Topics discussed include location and occupancy data, sales and production data, and characteristics of manufactured home occupants. For many of these topics, comparisons are made between occupants of manufactured homes (MH) and other single family detached homes (OSFDH).

The discussion is drawn from three principal surveys. One survey is the 1980 Census of Housing conducted by the U.S. Bureau of the Census. The second survey is the 1983 Pacific Northwest Residential Energy Survey (PNWRES) conducted for BPA by Louis Harris and Associates. (1) This survey was administered to approximately 4700 respondents by in person interviews conducted between llay 27 and September 4, 1983. The third survey, The Marketing Environment for Energy Conservation in the Pacific Northwest, was conducted by RllH Research, Inc. for PNL and BPA. (2) It was administered to 2000 respondents by telephone between October 30 and November 13, 1983. Both the PNWRES and RMH surveys were administered to residents in the Pacific Northwest region as this term is defined in the Regional Power Act. (3) The PNWRES and RMH surveys are also cited in the Section 6.0 discussion on manufactured home owners' and buyers' interest in and attitude toward energy conservation.

The three surveys cited above do not distinguish between occupants of manufactured homes and trailers used as a usual residence. Trailers are a category of manufactured housing that technically fall outside the HUD MHCSS, generally because they are less than $400 \mathrm{sq} f t .(4)$ Consequently, trailers are not built to the HUD manufactured home construction standards. No information was found indicating how many Northwest residents use a trailer as their principal dwelling unit and typical survey data must be qualified by the fact that trailer and manufactured home occupants may be grouped together. All numbers for manufactured homes and their occupants from these two surveys include numbers for trailers used as a usual residence and their occupants. In the PNWRES 
survey, 653 of the respondents indicated that a manufactured home or a trailer was their principal dwelling unit. The comparable number in the RMH survey was 132.

\subsection{LOCATION AND OCCUPANCY DATA}

Data from the 1980 Census of Housing on the numbers and Tocation of manufactured homes (and trajlers used as a usual residence) are shown in Table 2.: for Idaho, Oregon, and Washington. Comparable data are included for other single family detached homes. In 1980, manufactured homes made up $14 \%$ of the total number of single family detached homes in Idaho, $11 \%$ in Oregon, and $9 \%$ in Washington.

Manufactured homes are much more likely to be located in rural areas than other single family detached homes. As shown in Tabie 2.1, in 1980 the percentage of manufactured homes in urban areas for the three states ranged from 30-33\% of total 14 units within the state. For other single family detached

TABLE 2.1. Numbers and Location of Housing Inits (1980)

\begin{tabular}{|c|c|c|c|}
\hline Number of Units & Idaho $(5)$ & Oregon $(6)$ & Washington (7) \\
\hline Total Year Round Housing Units & 360,031 & $1,071,613$ & $1,551,680$ \\
\hline $\begin{array}{l}\text { lHs and Trailers } \\
\text { Percent of Total }\end{array}$ & $\begin{array}{r}40,950 \\
11 \%\end{array}$ & $\begin{array}{r}89,826 \\
8 \%\end{array}$ & $\begin{array}{r}105,261 \\
6 \%\end{array}$ \\
\hline $\begin{array}{l}\text { OSFDH } \\
\text { Percent of Total }\end{array}$ & $\begin{array}{r}251,593 \\
70 \%\end{array}$ & $\begin{array}{r}711,846 \\
66 \%\end{array}$ & $\begin{array}{r}1,112,525 \\
67 \%\end{array}$ \\
\hline \multicolumn{4}{|l|}{$\begin{array}{l}\text { Percent of Units in } \\
\text { Urban Location }\end{array}$} \\
\hline $\mathrm{MH}$ & $33 \%$ & $31 \%$ & $30 \%$ \\
\hline OSFDH & $53 \%$ & $67 \%$ & $62 \%$ \\
\hline
\end{tabular}

(a) An urban location is defined by the Bureau of the Census as 1) an incorporated area of 2,500 or more inhabitants but excluding housing units in the rural portion of extended cities, 2) census designated places of 2,500 or more inhabitants, and 3) other territory, incorporated or unincorporated, included in urban areas. 
homes, the comparable range was 53-62\%. The data in Table 2.2 are consistent with the greater propensity of manufactured homes to be sited in rural areas. A significantly higher percentage of the manufactured homes in the region are located in the high heating load areas east of the Cascade Mountains than the percentage of other single family detached homes.

TABLE 2.2. 1983 Location of Northwest Manufactured and Other Single Family Detached Homes $(2)$

$\begin{array}{lrr}\text { Manufactured Homes } & \text { West of Cascades } & \text { East of Cascades } \\ \begin{array}{l}\text { and Occupied Trailers } \\ \text { Other Single Family }\end{array} & 107,400(52 \%) & 97,400(48 \%) \\ \begin{array}{l}\text { Detached Homes } \\ \text { On }\end{array} & 1,580,400(67 \%) & 790,900(33 \%)\end{array}$

In spite of the fact that manufactured homes tend to be located in more rural areas than other single family detached homes, the two groups are served by public and investor owned utilities in the same proportion. Approximately $62 \%$ of the occupants of each category are served by investor owned utilities, and $38 \%$ are served by publicly owned utilities. (2)

Manufactured homes are somewhat more likely to be vacant than other single family homes as shown in Table 2.3. This tendency is likely enhanced by the inclusion of trailers used as a usual residence in the manufactured home data category. Although the 1980 census data showed that about $16 \%$ of manufactured and other single family detached homes were renter occupied, 1983 data from the RMH survey (Table 2.4) shows a slightly higher proportion (18\%) of manufactured homes occupied by renters.

TABLE 2.3. 1980 0ccupancy Status of Living Units

\begin{tabular}{|c|c|c|c|c|c|c|}
\hline & \multicolumn{3}{|c|}{ Manufactured Home } & \multicolumn{3}{|c|}{ OSFDH } \\
\hline & $\begin{array}{l}\text { Owner } \\
\text { Occupied }\end{array}$ & Vacant & $\begin{array}{c}\text { Renter } \\
\text { Occupied } \\
\end{array}$ & $\begin{array}{c}\text { Owner } \\
\text { occupied }\end{array}$ & Vacant & $\begin{array}{c}\text { Renter } \\
\text { Occupied }\end{array}$ \\
\hline Idaho $(5)$ & $73 \%$ & $11 \%$ & $16 \%$ & $77 \%$ & $7 \%$ & $16 \%$ \\
\hline Oregon $(6)$ & $76 \%$ & $9 \%$ & $15 \%$ & $77 \%$ & $6 \%$ & $17 \%$ \\
\hline Washington (7) & $76 \%$ & $8 \%$ & $16 \%$ & $79 \%$ & $5 \%$ & $16 \%$ \\
\hline
\end{tabular}


TABLE 2.4. 1983 Occupancy Status of Living Units (2)

\begin{tabular}{|c|c|c|}
\hline & Manufactured Home & OSFDH \\
\hline wner Occupis & $82 \%$ & $86 \%$ \\
\hline jied & $18 \%$ & $14 \%$ \\
\hline
\end{tabular}

\subsection{SALES AND PRODUCTION DATA}

Manufactured home placement data for 1984 are shown in Table 2.5. Slightly different housing start data for 1984 are shown in Table 2.6. Trailer sales data are not included in either Table. When the figures in the last column of Table 2.6 are compared to the figures from the 1980 Census of Housing in Table 2.1, it is apparent that manufactured housing is gaining an increasing share of the Northwest housing market. For example, in 1980 in Idaho, $11 \%$ of existing housing were manufactured homes or trailers used as a usual residence. In 1984, approximately $30 \%$ of all new housing units in Idaho were manufactured homes. For the four Northwest states, approximately $27 \%$ of new housing units in 1984 were MHs. Clearly, manufactured homes are providing a substantial fraction of new housing in the Northwest.

TABLE 2.5. New MHS Placed for Residential Use in $1984^{(8)}$

\begin{tabular}{|c|c|c|}
\hline & Single Section & Double Section \\
\hline Idaho & 1,000 & 900 \\
\hline Montana & 800 & 500 \\
\hline Oregon & 700 & 2,000 \\
\hline Washington & 2,000 & 3,700 \\
\hline Total & 4,500 & 7,100 \\
\hline
\end{tabular}

Of the total 1984 manufactured home placements in the four Northwest states (Table 2.5), 61\% were double section homes. This figure compares quite closely to the average of $58 \%$ for the entire West. ${ }^{(10)}$ In other parts of the country, however, single section manufactured homes are most common. Nationally, double-section homes accounted for $29 \%$ of total MH placements for residential use in $1984 .{ }^{(8)}$ 
TABLE 2.6. 1984 Housing Starts $(9)$

\begin{tabular}{lccc} 
MH Shipments (a) & $\begin{array}{c}\text { All other (b) } \\
\text { Single Family } \\
\text { Housing Units } \\
\text { Authorized }\end{array}$ & $\begin{array}{c}\% \text { MH of New } \\
\text { Single Family } \\
\text { Housing Units }\end{array}$ \\
\cline { 2 - 3 } Montana & 1,757 & $\frac{4,009}{30 \%}$ & $32 \%$ \\
Oregon & 1,267 & 2,654 & $27 \%$ \\
Washington & 2,915 & 7,975 & $17 \%$
\end{tabular}

(a) This column reflects the number of homes shipped to retail
sales sites and permanent locations within each state.
(b) This column includes units in multifamily buildings.

The higher proportion of multiwide homes in the Northwest accounts for the fact that there is a higher average sales price for new units. In 1984, the average manufactured home sales price in the four Northwest states, was $\$ 26,500 .(8)$ The average 1984 sales price of a double-section HH in the Northwest was $\$ 31,500$, and the average price of a single-section home was

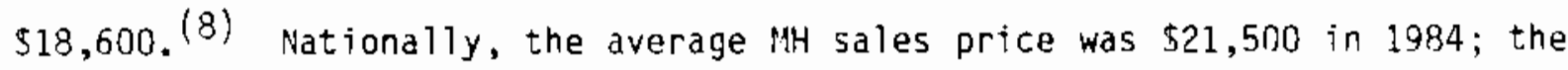
average double-section home sold for $\$ 30,400$ and the average single-section home sold for $\$ 17,700 .(8)$

The average square footage of new MHs in the Western U.S. was 1,395 in double-section and 920 in single-section homes in 1984.(8) Comparable areas nationally were 1,365 and 930 square feet.

The data in Table 2.7 show that in 1983 there were 31 manufacturing plants in the 4 Northwest states that produced 13,614 homes. Sales in 1983 totaled 11,892 units. (10) In 1984, production increased slightly in Idaho and declined somewhat in Oregon and Washington.

\subsection{TYPES OF HEATING FUELS}

Data on the types of space heating fuels used by manufactured and other single family detached home occupants in the Northwest are shown in Table 2.8. Over half of manufactured home occupants say they primarily use electricity for 
TABLE 2.7. Northwest Manufactured Home Production Figures(a)

\begin{tabular}{|c|c|c|c|c|c|}
\hline & $\begin{array}{r}\text { No of } \\
\text { Plants (1983) }\end{array}$ & $\begin{array}{l}\text { Single Section } \\
\text { Units Produfed } \\
(1983)(10) \\
\end{array}$ & $\begin{array}{c}\text { Double Section } \\
\text { Units Produfed } \\
(1983)^{(10)} \\
\end{array}$ & $\begin{array}{c}\text { Total } \\
\text { Productjop } \\
\text { (1983) }\end{array}$ & $\begin{array}{c}\text { Total } \\
\text { Productjog } \\
\text { (1984) (11) }\end{array}$ \\
\hline Idaho & 12 & 2,866 & 1,922 & 4,913 & 5,033 \\
\hline Montana & 1 & 205 & 61 & & \\
\hline Oregon & 14 & 2,808 & 4,188 & 7,079 & 6,818 \\
\hline Washington & 4 & 471 & 1,093 & 1,571 & 1,314 \\
\hline Total & 31 & 6,350 & 7,264 & & \\
\hline
\end{tabular}

(a) Total production figures for 1983 include homes other than single- and doublesection units.

TABLE 2.8. Primary Space Heating Fuel of Existing Northwest Single Family Detached Homes

\begin{tabular}{|c|c|c|c|c|}
\hline & \multicolumn{2}{|c|}{$:$ : } & \multicolumn{2}{|c|}{ OSFDH } \\
\hline & PNWRES (1) & $\mathrm{RMH}^{M}(2)$ & PNWRES (1) & $\mathrm{RMH}^{(2)}$ \\
\hline Electricity & $54 \%$ & $52 \%$ & $35 \%$ & $29 \%$ \\
\hline Wood & $30 \%$ & $32 \%$ & $34 \%$ & $32 \%$ \\
\hline Natural Gas & $7 \%$ & $11 \%$ & $17 \%$ & $25 \%$ \\
\hline LPG & $7 \%$ & & $1 \%$ & \\
\hline Fuel oil & $3 \%$ & & $11 \%$ & \\
\hline Coal & & & $1 \%$ & \\
\hline Other & $0 \%$ & $5 \%$ & $2 \%$ & $14 \%$ \\
\hline
\end{tabular}

space heating compared to only about a third of other single family detached home occupants. These data, of course, provide only limited information on the type of heating equipment actually installed in the homes. A surprising aspect of the data is that nearly a third of manufactured home occupants say they use wood as their primary heating fue1. This is approximately the same percentage as other single family detached homes. Since fireplaces and wood stoves are generally not a standard feature on new manufactured homes, the data suggest that many consumers are buying them as options on new homes or retrofitting existing homes. 
The primary space heating fuel by age category of the manufactured home is shown in Table 2.9. The percentage of homes using wood as the primary heating fuel is relatively constant across age categories. Thus 7 (33\%) of the 21 PNWRES survey respondents 1 iving in manufactured homes built between 1950 and 1959 stated that they use wood as their primary space heating fuel and 7 (33\%) of the respondents living in manufactured homes bujlt in 1982 . or 1983 also stated they use wood as their primary heating fuel. Although the percentage of respondents using wood as their primary fuel remains relatively constant, the survey data show a slight trend toward more $L P G$ and natural gas use and less electricity use among occupants of newer manufactured homes, but these interpretations must be qualified because of the relatively small sample size in age categories.

Between September 1981 and the spring of 1983, 10\% of nanufactured home occupants said they converted to a new primary heating fue?. (1) lost conversions have likely been to wood. Of those converting, $56 \%$ had used electricity as their primary heating fuel prior to September 1981, 19\% used LPF, 10\% used natural gas, $3 \%$ used fuel oil, and only $2 \%$ used wood.

Data on the primary water heating fuel in manufactured and other single family homes are shown in Table 2.10. For both categories, electricity is by

TABLE 2.9. Primary Space Heating Fuel by MH Age Category (1)

\begin{tabular}{|c|c|c|c|c|c|c|}
\hline & \multicolumn{6}{|c|}{ †H Construction nate } \\
\hline & $1950-$ & $1960-$ & $1970-$ & $1975-$ & $1979-$ & $1982-$ \\
\hline & 1959 & 1969 & 1974 & 1978 & 1981 & 1983 \\
\hline $\begin{array}{l}\text { Number of } \\
\text { Respondents }\end{array}$ & 21 & 122 & 186 & 173 & 105 & 21 \\
\hline Hood & $33 \%$ & $29 \%$ & $31 \%$ & $29 \%$ & $31 \%$ & $33 \%$ \\
\hline ETectricity & $48 \%$ & $43 \%$ & $47 \%$ & $65 \%$ & $63 \%$ & $52 \%$ \\
\hline Natural gas & $10 \%$ & $14 \%$ & $9 \%$ & $1 \%$ & $1 \%$ & $5 \%$ \\
\hline Fuel oil & $5 \%$ & $5 \%$ & $4 \%$ & $1 \%$ & $0 \%$ & $0 \%$ \\
\hline$L P G$ & $5 \%$ & $8 \%$ & $9 \%$ & $5 \%$ & $5 \%$ & $10 \%$ \\
\hline
\end{tabular}


TABLE 2.10. Primary Water Heating Fuel (1)

$\begin{array}{lrrr} & \frac{1 H}{2} & & \frac{O S F D H}{1} \\ \text { Wood } & 0 \% & 1 \% \\ \text { Electricity } & 85 \% & & 86 \% \\ \text { Natural fias } & 7 \% & 12 \% \\ \text { LPG } & 8 \% & 1 \%\end{array}$

far the most common heating source. These data are probably fairly good indicators of the percent of homes equipped with electric space heaters since homes typicaliy have the same fuel for their water and space heating, but occupants could use wood as their primary space heating fuel.

\subsection{CHARACTERISTICS OF MANIJFACTURED HOME DCCUPANTS}

This section contains information on the age, education, and income of Northwest occupants of manufactured and other single family detached homes. The data are contained in Tables 2.11, 2.12, and 2.13. The data may not be precise indicators for future buyers of manufactured homes, but they do provide a strong indication of the buyers' likely characteristics.

The adult occupants of manufactured homes are somewhat more likely than occupants of other single family detached homes to be less than 35 years old and older than 55 as shown in Table 2.11. The data are consistent with other studies that have shown that young married couples and people of retirement age are major customers for manufactured homes. (12) Another statistic that might be relevant for conservation marketing is that in 1980 in the western II.S., only $21.3 \%$ of family units in owner occupied manufactured homes and trailers had children under the age of 18. (12) This percentage was higher in all other sections of the country, with the north central region having the highest percent age-- $38.8 \%$. (12)

Adult occupants of manufactured homes have lower incomes and less formal education, on average, than do occupants of other single family detached homes. Supporting data for these observations are shown in Tables 2.12 and 2.13. 
TABLE 2.11. Age of Adult Northwest Single Family Detached Home Dccupants

\begin{tabular}{|c|c|c|}
\hline \multicolumn{3}{|c|}{ PNWRES Survey (1) } \\
\hline in Yge & $\begin{array}{c}\text { Manufactured } \\
\text { Home }\end{array}$ & OSFDH \\
\hline$<35$ & $39 \%$ & $32 \%$ \\
\hline $35-54$ & $28 \%$ & $36 \%$ \\
\hline $55+$ & $33 \%$ & $32 \%$ \\
\hline
\end{tabular}

\begin{tabular}{ccc}
\multicolumn{3}{c}{ RMH Survey $(2)$} \\
\cline { 1 - 2 } in Years & $\begin{array}{c}\text { Manufactured } \\
\text { Home }\end{array}$ & $\frac{\text { OSFDH }}{28 \%}$ \\
\cline { 2 - 3 }$<34$ & $35 \%$ & \\
$34-54$ & $29 \%$ & $44 \%$ \\
$55+$ & $36 \%$ & $28 \%$
\end{tabular}

TARLE 2.12. Education Level of Adult Northwest Single Family Detached Home Occupants

\begin{tabular}{|c|c|c|c|c|}
\hline & \multicolumn{2}{|c|}{ PNWRES Survey $(1)$} & \multicolumn{2}{|c|}{ Rl'lH Survey (2) } \\
\hline & $\begin{array}{c}\text { Tanufactured } \\
\text { Home }\end{array}$ & OSFDH & $\begin{array}{l}\text { Tanufactured } \\
\text { Hone } \\
\end{array}$ & OSFDH \\
\hline $\begin{array}{l}\text { High School Graduate } \\
\text { or Less }\end{array}$ & $65 \%$ & $47 \%$ & $64 \%$ & $41 \%$ \\
\hline Some college or More & $35 \%$ & $53^{a t}$ & $36 \%$ & $59 \%$ \\
\hline
\end{tabular}

TABLE 2.13. Before Tax Household Income of Northwest Single Family Detached Home Dccupants

$\%$ of Households with Income

$<\$ 16,000$

$\$ 16,000-\$ 30,000$

$>\$ 30,000$

\begin{tabular}{|c|c|}
\hline $1982^{\prime}$ & \\
\hline $\begin{array}{c}\text { Manufactured } \\
\text { Home }\end{array}$ & OSFDH \\
\hline $54 \%$ & $39 \%$ \\
\hline $33 \%$ & $34 \%$ \\
\hline $12 \%$ & $27 \%$ \\
\hline
\end{tabular}

\begin{tabular}{|c|c|}
\hline $1983^{(}$ & \\
\hline $\begin{array}{c}\text { Manufactured } \\
\text { Home }\end{array}$ & OSFDH \\
\hline $45 \%$ & $21 \%$ \\
\hline $41 \%$ & $44 \%$ \\
\hline $14 \%$ & $35 \%$ \\
\hline
\end{tabular}




\section{REFERENCES AND NOTES FOR SECTION 2.0}

1. Louis Harris and Associates, Inc., New York, N.Y., Pacific Northwest Residential Energy Survey, DOE/BP-328, NTIS PC A05, 1984.

2. RMH Research Inc., River Edge, N.J., The Marketing Environment for Energy Conservation in the Northwest - Detailed Cross-Tabulation and Computer Printout, prepared for PNL and BPA, May 1984.

3. The Pacific Northwest Electric Power Planning and Conservation Act defines the Pacific Northwest region at 16 U.S.C.A. 839a(14) as: (A) the area consisting of the States of Oregon, Washington, and Idaho, the portion of the State of Montana west of the Continental Divide, and such portions of the States of Nevada, Utah, and Wyoming as are within the Columbia River drainage basin; and (B) any contiguous areas, not in excess of seventyfive air miles from the area referred to in subparagraph (A), which are a part of the service area of a rural electric cooperative customer served by the (BPA) Administrator on December 5, 1980 which has a distribution system from which it serves both within and without such region.

4. Inder the HUD MH definition (Ref. 12, Section 1.0), a $: 1 H$ that is 320 or more square feet is subject to the MHCSS. However, MHs between 320 anc 400 square feet have been exempted. HUD is considering the adoption of special construction standards for $M$ Hs between 320 and 400 square feet. 50 Federal Register 17319, April 29, 1985.

5. U.S. Bureau of the Census, Detailed Housing Characteristics Idaho, HC80-1B14, June 1983.

6. 1).S. Bureau of the Census, Detailed Housing Characteristics Oregon, HC801-B39, August 1983.

7. U.S. Bureau of the Census, Detailed Housing Characteristics Washington, HC80-1-849, July 1983.

8. U.S. Bureau of the Census, Construction Reports Housing Starts, C20-85-5, June, 1985.

9. Automation in Housing and Manufactured Home Dealer, CMN Associates Inc., Carpinteria, California, p. 40, April 1985.

10. LSI Systems, Inc., Crofton, Maryland, where the Action Is: A Geographic Analysis of the Nation's Manufactured Housing Industry, 1984.

11. Mobile/Manufactured Home Merchandiser, RLD Group, Chicago, IL, p. 10, April 1985. The figures are compiled by the National Conference of States on Building Codes and Standards, Herndon, Virginia.

12. Business Trend Analysts, Commack, New York, The Mobile Home Industry, April 1984. 


\subsection{MANUFACTURED HOME ENERGY CONSERVATION OPTIONS AYAILABLE IN THE PACIFIC NORTHWEST}

To better understand the market for manufactured homes and energy-related options and equipment for these homes, it is useful to examine recent buying decisions made by consumers within this market. This section discusses survey information on energy conservation options available in manufactured housing sold in the Northwest. The principal source of data is a survey administered to 10 MH manufacturers in early 1984 by the llanufactured Housing institute. (1) A second source is limited data obtained by PNL from a letter questionnaire sent to 24 manufacturers of $11 \mathrm{Hs}$ sold in the Northwest in February, 1985. Only 2 of the 24 manufacturers responded to the PNL survey. In follow up telephone conversations, the information requested was found to be either very time consuming to collect or unavailable. A personal interview would likely be necessary to obtain a higher response rate.

The information collected from the PNL questionnaire is discussed in Section 3.2. Section 3.1 contains the verbatim reproduction of the survey on energy efficiency options sponsored by the llanufactured Housing Institute (I:HI). Nine of the 10 builders questioned in the l?HI survey are listed in the top 25 national builders of 1982. Only selected survey results pertaining to the Northwest are reproduced.

\subsection{MHI SURVEY OF THERMAL OPTIONS OFFERED BY MANUFACTURED HOME BUILDERS (1)}

Ouestion One $^{(1)}$

Are you selling energy packages over and above the Minimum Hul Title VI Standards? Are they above the Title II Standards?(a) Is there a regional breakdown? What percentage of your homes are in these categories?

(a) The Title VI standards are the HIID IHCSS at 24 C.F.R. 3280. Title II standards come from the Federal Housing Act of 1949 which implemented loan programs for all types of housing including manufactured housing. To qualify for these loans, an owner's home must meet the Title II standards, which are more strict than Title VI requirements. 
Company

A

B

C

D

Response

Yes, for our northern plants $90 \%$ of the homes we sell have an energy package equal or better than the Title II Standards. In our southern plants, $10 \%$ to $15 \%$ of home buyers buy one of our very efficient energy packages.

Yes, we offer several packages for the homes we sell. In the northeast, north central and northwest regions, $50 \%$ of our home buyers select some type of energy option. They generally equate to the Title II options, some being above and some being less in energy efficiency. In the southeast Piedmont region, the nuke Power Program is encouraging our home buyers to select a plan which meets their minimum standards, which exceeds the Title II requirements.

\footnotetext{
Yes, we market energy packages throughout the Innited States, and those we sell are close to the Title II Standards, particularly in the northern tier of states. In the northwest, $30 \%$ to $50 \%$ of our home buyers choose a rather extensive package option. In one state, Idaho, 2 in. $x 6$ in. walls are standard in our homes. And in that state, three-fourths of the home buyers select an upgrade in the roof thermal efficiency.
}

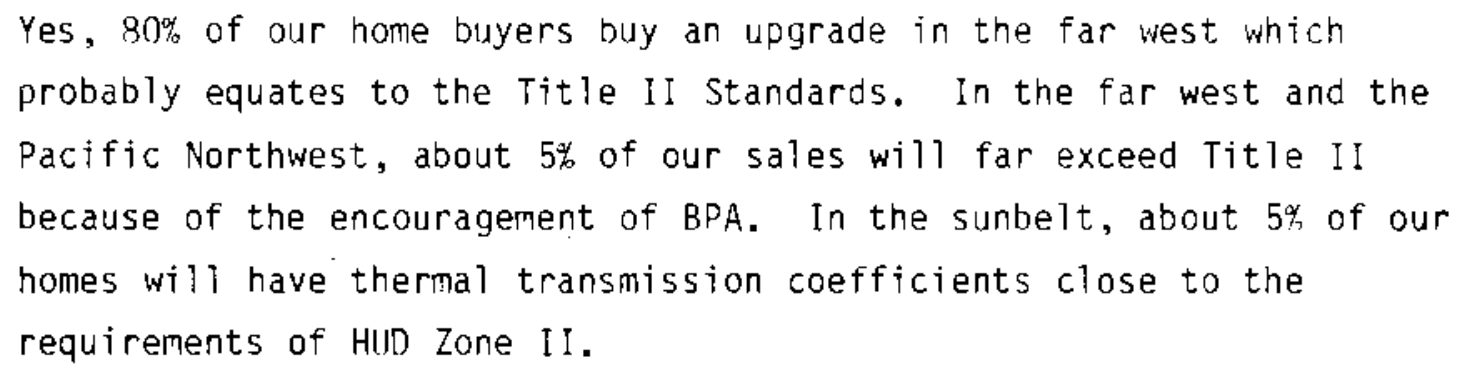
Pacific Northwest, about $5 \%$ of our sales will far exceed Title II because of the encouragement of BPA. In the sumbelt, about $5 \%$ of our homes will have thermal transmission coefficients close to the requirements of HIJ Zone II.

Ouestion Two:

What types of energy conservation options are you offering, and what are the wholesale prices? (Wholesale prices are normally about three-fourths of the retail price. That is, the retail price is obtained by multiplying the following prices by 1.33. ) 
In the Pacific Northwest we offer several packages. The first would upgrade insulation levels in roof, walls and floors at a cost of $\$ 300$. The second package, more expensive than the first, would add to the first: double glazing, wrapped heating ducts, wrapped water heater and a set-back thermostat at wholesale cost ranging hetween $\$ 750$ and $\$ 1100$. A third package would increase still further the levels in walls and floors and add? in. $\times 5 \mathrm{in}$. walls. These packages would range in price between $\$ 1100$ and $\$ 1500$, depending on the size of the home. Still another package would increase roof, walls and fioor insulation with 2 in. $x 6$ in. walls, hut not adding wrapped heating ducts and other items noted above, at a price range between $\$ 9 n 0$ and $\$ 1100$. Finaliy, a separate option provides double glazing for homes at wholesale costs of about $\$ 450$ per home.

We market throughout the United States, packages which increase the roof, walls and floor insulation at a wholesale cost between $\$ 10 n$ and $\$ 350$. Where we add an air infiltration harrier, we add approximately $\$ 150$ more per home.

6. Our market in the south includes homes with blown-in insulation in the ceiling at about R-16, R-11 in the wall and between R-0 and R-11 in the floor. In the OKlahoma area we offer packages which upgrade from R-7 in the floor, walls and ceiling to R-12, R-12 and R-25 and double-glazed windows. In the Pacific Northwest, we upgrade from a hasic package of R-11 in the floor, walls and ceiling and double glazing to $R-12, R-12$ and $R-26$. In Alaska, our hasic package with double glazing has $R-14$ in the floor, $R-11$ in the walls and R-14 in the ceiling and we upgrade that to $R-17$ in the floor, R-17 in the walls and R-33 in the ceiling. In the Pacific Northwest, our upgraded packages range hetween $\$ 200$ and $\$ 700$ wholesale.

1) In the far west, $80 \%$ of our home huyers opt for insulation levels of $R-11$ in the floor, R-11 in the walls and R-21 in the ceiling. About 
5\% opt for a package which would have an average of $\mathrm{R}-11$ in the floor, R-19 in the walls and R-28 in the ceiling. These homes would have single glazing and only about $10 \%$ glazing as a percentage of the floor area where the minimum is $8 \%$. In the sunbelt, about $5 \%$ of our home buyers opt for between $R-11$ and $R-14$ in the floor, between $R-13$ and $R-19$ in the walls and R-30 to R-33 in the ceiling. With glazing areas between $8 \%$ and $12 \%$. In the Pacific Northwest, about $5 \%$ of our buyers opt for $R-22$ in the floor, $R-19$ in the walls and $R-33$ in the ceiling with double glazing a minimum of $8 \%$.

\subsection{PNL SURVEY RESULTS}

The two manufacturers who responded to the PNL questionnaire hold a large combined share of the Northwest manufactured home market. Their responses provide a rough estimate of what is being offered to the consumer in tems of energy conservation options, and the wholesale price (cost to the dealer) of these options.

Typical energy efficiency upgrade options are shown in Table 3.1. Insulation R-values are presented in Table 3.1 for ceilings, walls and floors, respectively. The standard insulation " $R$ " values for ceiling, walls, and floors respectively ranged from $R-14-7-7$ to $R-14-11-7$. Option packages available varied depending on the standard insulation available.

One of the manufacturer respondents estimated that the following characteristics are descriptive of the various types of homes it sells:

- $75 \%$ of homes they construct have R-21-11-11 insulation

- $1 \%$ of homes they construct are heat pump ready

- 3\% of homes they construct have $2 \times 6$ walls

- 99\% of homes they construct are all electric.

Thus, it appears that most consumers select insulation levels above standard ievels, but not too much greater. This most common insulation upgrade, given a $33 \%$ mark-up, would cost the consumer about $\$ 400$ for a single wide home and $\$ 533$ for a double wide. 
TABLE 3.1. Typical Option Availability and Cost from PNL Letter Survey

Energy Efficiency Options

R-21-11-11 insulation levels

$R-33-11-11$ ( $R-21$ in cathedrals)

insulation levels

6 inch walls + R-21-19-11 insulation levels

6 inch walls + R-33-19-44 ( $R-21$ in cathedral

ceilings) insulation levels

Foam core roof

Foam core walls

R-21-11-14 insulation levels w/deluxe storms, water heater wrap, set-back thermostat and shower flow restrictions

Heat pump ready
Wholesale Price Single Wide Double Wide

$\$ 300$ $\$ 400$ $\$ 700$ $\$ 800$

$\$ 1400$

$\$ 220$

$\$ 300$

$\$ 270$

$\$ 300$

$\$ 740$

$\$ 1100$

$\$ 25$ 
1. Frank Walter, Manufactured Housing Institute, "Survey of Thermal Options Offered by Manufactured Home Builders," March 12, 1984. 


\subsection{COST AND PERFORMANCE OF ENERGY SAVING OPTIONS}

The purpose of this section is to provide information about the economic performance of the various energy conservation options (ECOs) offered by manufacturers. The economic impacts of buying upgraded options are presented from the consumer's perspective, based on a number of decision-making criteria. The intent is to provide some understanding of consumers' probable responses to opportunities for investment in ECOS. The economic evaluations are therefore conducted from the individual consumer's perspective, and do not reflect the impact of those ECOs on the Northwest as a whole.

In general, the performance of a particular ECO is dependent on the other thermal options present in the home. For example, due to the increased load on the building, a high-efficiency furnace will save more energy in a poorly insulated house than in one that is well insulated. This interrelation complicates the analysis of energy and economic performances of ECOs. The determination of the most economical combination of options is typically a problem of optimization, specific to given climatic and economic environments. For this study, however, it is desirable to analyze the various options available to the consumer in isolation from one another. Though this approach inherently contains some degree of inaccuracy, reasonable estimates of energy performance can be obtained for certain options without significant error. The energy estimating method used in this analysis minimizes that error.

This approach precludes the analysis of a few available options, primarily equipment efficiencies and their interactions with envelope options. Included are the various options related to the envelope of the manufactured homeceiling insulation, wall insulation, floor insulation, and window type. These are the components of energy consumption most driven by climatic conditions, least related to occupant behavior, and most typically offered as options by manufacturers.

Section 4.1 describes the manner in which energy use and savings figures were calculated. Section 4.2 contains a discussion of the sources of ECO costs used in the analyses. The economic criteria and methodologies used to compare options are described in Section 4.3 , and the assumptions regarding economic 
input parameters are discussed in Section 4.4. Lastly, Section 4.5 presents the results of the comparisons.

\subsection{ENERGY ESTIMATING METHOD}

In order to assess the economic impact of an ECO, it is necessary to estimate the effect it has on the annual heating and cooling loads of the home. A number of methodologies exist for such analyses. The tool chosen for this study is a data base developed in 1984 by Steven Winter Associates for the Department of Energy. (1) The data base is derived from the output of numerous computer simulations of manufactured homes of varying thermal integrity (insulation level and window type) and location using the DOE 2.1A butiding energy performance model. (2)

The computer analyses were based upon prototype single-section and double-section manufactured homes which represent common construction practices in the Inited States. The structure of the resulting data base is that of a base load in millions of Btu's (MMBtu) for the "base case" prototype and load reductions ("de1tas") realized by upgrading the therma? integrity of envelope components to specified levels. The levels of insulation and window types available in the data base are given in Table 4.1, and are the options compared in this analysis. Window areas are assumed to be equal to $10.9 \%$ of floor area for singie-sections and $10.3 \%$ for double-sections. Infiltration, though a significant contributor to the overall building load, was neglected, and has no effect. on the results of this analysis. Predictions of infiltration levels are difficult to quantify accurately.

The use of a such a data base for estimating space conditioning energy requirements has a number of advantages for this application. First, the determination of the energy performance of an ECO in a particular location involves only referencing a table. Second, envelope ECOs may be assumed to be independent of each other in evaluating their performance. The error of this assumption is minimized because the interrelations present in common combinations of options were accounted for in the computer simulations. Significant 
TABLE 4.1. Envelope Conservation Features Available in the Energy Data Base

\begin{tabular}{|c|c|c|c|}
\hline $\begin{array}{c}\text { Roof } \\
\text { Insulation }\end{array}$ & $\begin{array}{c}\text { Wall } \\
\text { Insulation }\end{array}$ & $\begin{array}{l}\text { Floor } \\
\text { Insulation }\end{array}$ & Window Type \\
\hline$R-7$ & $\mathrm{R}-7$ & $R-7$ & Single Pane, Aluminum Sash \\
\hline$R-11$ & $\mathrm{R}-11$ & $R-11$ & Single Pane, Aluminum Sash \\
\hline$R-14$ & $R-13$ & $R-14$ & with Thermal Breaks \\
\hline$R-19$ & $\mathrm{R}-19$ & $R-19$ & Double Pane, Aluminum Sash \\
\hline$R-22$ & $R-18^{(b)}$ & $R-2 ?$ & Double Pane, Alurinum Sash \\
\hline$R-30$ & $R-24^{(b)}$ & $R-28$ & with Thermal Breaks \\
\hline$R-38(a)$ & & & $\begin{array}{l}\text { Any of the above with movable } \\
\text { storm windows }(c)\end{array}$ \\
\hline
\end{tabular}

(a) Only available in data base for double-wide homes.

(b) R-18 consists of $R-13$ batt between studs plus an $R-5$ sheath under siding. $Q-24$ consists of $R-19$ batt between studs plus an $R-5$ sheath under siding.

(c) Wood sash is also included in the data base, but was not used for comparison because it is uncommon in manufactured homes and is very costly.

error can be expected only when uncommon combinations of options are analyzed. An example might be a home with R-33 insulation in the roof, but only R-7 in the walls and fioor. Such atypical constructions were not modeled in the data base development process. The standard nature of manufactured home designs and configurations makes them particularly well suited to data base analysis, as most homes are very similar to the prototypes used for development of the data base.

The economic performances of envelope ECOs were evaluated for two prototype manufactured homes, single-section and double-section, in three Northwest cities representing each of the three Model Conservation Standards (MCS) climate zones. The cities are listed in Table 4.2 along with their respective annual heating degree days. (3) 
TABLE 4.2. Northwest Cities Included in ECO

Cost/Performance Analyses

\begin{tabular}{lccc} 
City & \multicolumn{2}{c}{$\begin{array}{c}\text { Annual Degree-Days } \\
\text { (base 65 F) }\end{array}$} & $\frac{\text { MCS }}{\text { Zone }}$ \\
\cline { 1 - 2 } Portland, OR & 4635 & 1 \\
Spokane, WA & 6655 & 2 \\
KalispeI1, MT & 8191 & 3
\end{tabular}

\subsection{CONSERVATION OPTION COST SOURCES}

The primary source of cost information is a data base of manufacturers' costs developed by Steven Winter Associates to accompany the energy data base referenced in Section 4.1. The data represent national average (1984) costs to manufacturers of obtaining and installing the various envelope conservation options. Only those costs which vary between different levels of a given ECO are included in the data. That is, the numbers do not necessarily represent actual absolute costs, but rather the marginal costs of upgrading the components from some base level to specified levels of thermal integrity.

The manufacturers' costs were nultiplied by 1.57 to obtain the dealers' costs. The dealer costs were multiplied by 1.33 and a national average sales tax of $3.25 \%$ was added to obtain retail cost estimates.(4) These price mark-up factors, obtained informally from the Department of Housing and Urban Development, represent national averages. Since the data base costs also represent national averages, the resulting retail prices were then adjusted by Means(5) regional construction cost multipliers and converted to 1985 dollars using an inflator of 1.03 .

The Steven Winter Associates costs were compared randomly to the prices of several energy conservation features as quoted by area distributors. In general, the data base costs agreed with actual retail costs to within $20 \%$. The data base costs were typically slightiy higher than those reported by dealers. A few examples are shown in Table 4.3. 
TABLE 4.3. Comparison of Cost Data Base with Actual Prices

\begin{tabular}{|c|c|c|c|}
\hline $\begin{array}{c}\text { Base } \\
\text { Configuration } \\
\end{array}$ & $\begin{array}{c}\text { Upgraded } \\
\text { Configuration }\end{array}$ & $\begin{array}{c}\text { Quoted } \\
\text { Cost } \\
\end{array}$ & $\begin{array}{l}\text { Data Base } \\
\text { Cost } \\
\end{array}$ \\
\hline $14-7-7^{(a)}$ & $21-11-11$ & $\$ 510$ & $\$ 570$ \\
\hline $14-7-7$ & $21-19-11$ & $\$ 1032$ & $\$ 1121$ \\
\hline $14-7-7$ & $33-19-14$ & $\$ 1780$ & $\$ 1637$ \\
\hline
\end{tabular}

(a) The numbers represent nominal insulation R-values for the ceiling, walls, and floor, respectively.

\subsection{ECONOMIC EVALUATION METHODOLOGY ANO CRITERIA}

This section describes the economic criteria used in the evaluations of the ECOs. Section 4.3.1 discusses the base against which the various options are compared. Section 4.3.2 lists the economic criteria and constraints. Section 4.3.3 discusses the relevance of the various criteria to this study. 4.3.1 Establishment of a Baseline for Comparison of Options

The first step in comparing alternative ECOs is to establish a baseline or base case against which to compare the options. The base configuration should represent typical or standard practice. For the purposes of this study, the base case is assumed to be a home which complies with the HUO MHCSS at the lowest possible first cost. Each available ECO is compared against the corresponding component of the base case home.

The HUD MHCSS contains a non-prescriptive thermal performance standard which allows compliance through an unlimited number of combinations of thermal options. The standard requires a maximum overall U-value for the entire building envelope, with no specific requirements for most components. The only exception involves windows, which must be either double glazed or include storm windows at a minimum. (6) Thus, a home with poorly insulated walls could compensate with a very well insulated ceiling and still meet the standard. Typical current construction practices in the Northwest meet the minimum HUO requirements in a variety of ways, the most common being a combination of $R-14$ insulation in the ceiling, R-7 in the walls, R-7 in the floor, and double-paned 
windows mounted in aluminum sash. A number of other standard combinations are available, however, which also meet or exceed the standard.

The ECOs preferred on the basis of some economic evaluations (specifically those involving short-term criteria) may depend on the baseline assumed. For example, in the configuration above, upgrades to the floor and wall would probably be preferred over upgrades to the ceiling because the base cases for those two components are considerably lower. The base case must therefore se carefully chosen so as to treat all availabie Ecos equitably.

In order to minimize any bias due to base case selection, an attempt was made to establish the minimum first cost configuration which would just meet the criteria of the HUD standard. Based on the costs from the data base and the design of the prototypes used in the energy simulations, a base case combination was established as follows: R-11 in the ceiling, R-7 in the walls, R-7 in the floor, and single-pane windows with aluminum sash plus movable storm windows. It should be noted that this combination may not neet the HUD requirements in all homes. Compliance is dependent on a number of factors, including ceiling, wall, and floor construction materials, and window area.

\subsubsection{Economic Criteria}

The criteria used in comparing and ranking the Ecos include net life cycle cost, simple payback period, and annual cash flow. The net discounted life cycle cost analysis considers the first cost of each upgrade from the base configuration, the increase in down payment required of the consumer, the increase in annual mortgage payments, the energy savings over the life of the ECO, and the income tax deductions available to the consumer for the interest payments on the mortgage. Costs and savings each year are discounted to equivalent present value (1985) dollars and summed to obtain the net cost to the consumer.

The simple payback period is the number of years required for the energy savings realized by an ECO to recover its initial cost, assuming that the value of money is constant. This metric also assumes that the cost of energy is constant. That is, electricity costs neither increase nor decrease during the payback period. 
The annual cash flow analysis considers the increasing (or decreasing) cost of fuel through the years due to inflation and real fuel escalation rates. Actual fuel consumption is considered to remain constant each year. The cash flow is defined as the energy (nominal dollar) savings realized in any year minus the increase in mortgage payments due to the investment in the ECO. Two cash flow values are used for comparison. One is the number of years required before the annual reduction of fuel bills equals or exceeds the increase in annual mortgage payments. The other is the net cash flow realized in the first year, not including the down payment.

\subsubsection{Relevance of the Economic Criteria to Marketing of ECOs}

In general, a comparison of investment alternatives should always consider the life cycle cost of each option in order to capture all relevant costs and benefits. However, consumers are often unfamiliar with terms such as "ijfe cycle cost" or "discount rate" and are more concerned with short-term economic considerations. Typically, the simple payback period is the most meaningful to the consumer.

There are, however, a number of problems associated with the use of simple payback as a comparison criterion which are significant to this study. First, it tends to bias results toward selection of the less energy efficient options. Because the amount of energy saved per increment of increased thermal integrity typically decreases with increasing insulation levels, the lower levels almost always have shorter payback periods. Second, the simple payback period is very sensitive to the selected base case themal integrity levels. Finally, it neglects all future benefits after the payback occurs. From an investment choice perspective, simple payback provides virtually no information about the return on investment. Nevertheless, consumers are very conscious of payback periods, especially if they do not expect to live in the home for an extended period of time.

Life cycle cost analysis reveals the most economical options over the entire useful life of the home. Changes in the value of money and in the cost of energy over time are taken into account, as well as the fact that not all the cost of each ECO is paid at the time of purchase. The latter is another weakness of payback analysis. If the consumer understands that the majority of 
the costs and benefits of energy conserving upgrades are encountered in future years, perhaps life cycle cost will make more sense. To a consumer who does not plan to live in a home for its entire useful life, this fact is best understood as a promise of a higher resale value.

The disadvantage of life cycle cost analysis, in addition to consumers lack of acceptance, is its sensitivity to the assumed economic input parameters. This aspect is discussed in the following sections.

The annual cash flow analysis compares the increase in annual mortgage payments to the decreases in annual fuel bills. It is ideal that the energy savings due to the ECO equal or exceed increased mortgage payments in the first year. However, it is often the case that the most economical option results in negative cash flows during the first few years. Knowledge that positive cash flows are only a few years away might be helpful in selling the option to the consume $r$.

\subsection{ECONOMIC PARAMETERS CHOSEN FOR THE COMPARISONS}

This section discusses the assumptions used in calculating the life cycle cost of each envelope option. The assumptions are intended to represent the perspective of a typical manufactured home buyer. The required inputs and their assumed values are given in Table 4.4, and discussed in the following paragraphs.

TABLE 4.4. Economic Parameters Used in Life Cycle Cost Comparisons

\begin{tabular}{lr}
\multicolumn{1}{c}{ Parameter } & $\frac{\text { Value }}{\text { Useful life of home (years) }}$ \\
Length of mortgage (years) & 30 \\
Interest rate on mortgage $(\%)$ & 16 \\
Down payment required $(\%)$ & 17 \\
Annual inflation rate $(\%)$ & 3 \\
Annual discount rate (real) $(\%)$ & 20 \\
Marginal tax rate $(\%)$ & 100 \\
Heating equipment efficiency $(\%)$ & 220 \\
Cooling equipment efficiency $(\%)$ &
\end{tabular}




\subsubsection{Assumptions Regarding the Home Mortgage}

The interest rate and length of mortgage are based on the average values discussed in section 5.1. Though mortgage parameters for manufactured homes are tending toward those of site-built homes, their equality is not yet a reality.

\subsubsection{Assumptions Regarding Discount and Tax Rates}

The selection of an appropriate discount rate is difficult to defend in the context of a homeowner. One might contend that consumers typically have short-term perspectives, and that a high discount rate is justifiable. On the other hand, most alternative investments available to typical homeowners will seldom pay a real return in excess of $2 \%$ to $4 \%$. The real discount rate of $3 \%$ chosen here is intended to reflect the latter contention. It is also the rate used by the Northwest Power Planning Council in developing the l"odel Conservation Standards (though the council used a completely different methodology and perspective than described here).

Since most manufactured home buyers have gross annual incomes below $\$ 30,000$ (see Table 2.13), a marginal tax rate of $20 \%$ was selected. This rate should be viewed as representing both federal and state taxes though it was not derived for any particular set of circumstances. The value is illustrative only, and clearly varies from consumer to consumer.

\subsubsection{Assumptions Regarding Fuel Prices and Equipment Efficiencies}

Electricity prices used in all scenarios were actual current costs as of May, 1985, in each city considered. Prices were obtained by direct query of the suppliers. These values are shown in Table 4.5. The given prices include all applicable taxes and adjustments. Where utilities have block rate structures, prices were taken from the highest block in which the typical residence is likely to operate.

Fuel escalation rates were taken from Federal Energy Management Program $(7)$ (FEMP) quoted values as of March, 1984. The rates in Table 4.6 are reat rates projected for DOE Region 10, which includes the Northwest area of interest. Following a review of current projections, ${ }^{(8)}$ an annual inflation rate of $5 \%$ was assumed for the entire period of analysis. 
TABLE 4.5. Current Flectricity Prices in the Northwest (cents/kWh)

\begin{tabular}{|c|c|c|}
\hline City & Summer & Winter \\
\hline Portland, $\mathrm{OR}$ & 3.8433 & 40 \\
\hline Spokane, WA & 4.5480 & 4.5480 \\
\hline Kalispe11, MT & 4.5170 & 5.1 \\
\hline
\end{tabular}

IABLE 4.6. Real Electricity Price Escalation Rates

\begin{tabular}{|c|c|}
\hline Year & $\begin{array}{l}\text { Real } \\
\text { Escalation Rate }\end{array}$ \\
\hline $1984-1985$ & $-1.23 \%$ \\
\hline $1985-1990$ & $-0.76 \%$ \\
\hline $1990-2009$ & $3.54 \%$ \\
\hline 2009 & $3.54 \%$ (as sumed) \\
\hline
\end{tabular}

Electric space heating and cooling equipment efficiencies were assumed to correspond to a central electric resistance furnace and a direct expansion electric air conditioner. The prototypes modeled for the energy data hase contained ductwork on the conditioned side of insulation, so the assumption of $100 \%$ efficient heating is reasonable. A seasonal air conditioner coefficient of Performance of 2.2 was assumed as typical for all scenarios. It should he recognized that the installation of HVAC equipment with different efficiencies (e.g., a heat pump for winter heating) may significantiy alter the effectiveness of envelope insulation options.

\subsection{COMPARISON OF ECONOMIC PERFORMANCE OF ENVELOPE OPTIONS}

This section describes the results of the economic comparisons of the available envelope upgrades above the hase configuration of R-11 insulation in the ceiling, R-7 in the walls and floor, and single pane aluminum sash windows with movable storm windows. The preferred combinations under the minimum life cycle cost decision-making criterion are presented as is information illustrating the relative effectiveness of upgrading different components. 


\subsubsection{Preferred Envelope Combinations}

The net life cycle cost to the consumer of each insulation and window option was calculated using the economic assumptions outlined in Section 4.4. The options resulting in the smailest net life cycle cost (or more accurately, the greatest life cycle savings), were combined to obtain the preferred packages for each city analyzed. Table 4.7 shows these packages.

Since the above configurations are based on life cycle cost analyses, it is desirable to exarine the impacts of these combinations on the short term economic criteria. In Tabie 4.8 , the simple payback periods and first year cash flows of the minimum life cycle cost combinations for each city are given. The year in which incremental energy savings equal or exceed incremental loan payments is also given for each case.

It is observed from Table 4.8 that first year cash flows are almost always positive for the scenario assumed here. Payback periods, though perhaps longer than some consumers are willing to accept, are not excessive to the point of being prohibitive.

\subsubsection{Ranking of the Envelope Options by Economic Effectiveness}

This section compares the relative effectiveness of upgrading each envelope component with respect to the other components. The purpose is to provide guidance as to which ECOs should be adopted first if limited investment funds are available.

TABLE 4.7. Preferred Packages Based on Minimum Life Cycle Cost

\begin{tabular}{|c|c|c|}
\hline City & Single-wide & Double-Wide \\
\hline Portland & 2?-19-22-1, storm (a) & 19-19-19-1, Storm \\
\hline Spokane & $30-19-22-2$, storm & $30-19-28-1$, Storm \\
\hline Kalispell & $30-24-22-2$, Storm & $38-24-28-2$, Storm \\
\hline
\end{tabular}

(a) The numbers represent the R-value of the ceiling, walls, and floor, respectively, followed by the number of panes in the primary window unit plus movable storm windows. 
TABLE 4.8. Payback Period (years), First Year Cash Flow, and Year in Which Cash Flow Becomes Positive of Optimum Packages Based on Minimum Life Cycle Cost $(a)$

\begin{tabular}{|c|c|c|c|c|c|c|}
\hline \multirow[b]{2}{*}{ City } & \multicolumn{3}{|c|}{ Single-Wide } & \multicolumn{3}{|c|}{ Double-Wide } \\
\hline & $\begin{array}{l}\text { Simple } \\
\text { Payback }\end{array}$ & $\begin{array}{l}\text { First Year } \\
\text { Cash Flow }\end{array}$ & $\begin{array}{l}\text { Change }(a) \\
\text { In LCC }\end{array}$ & $\begin{array}{l}\text { Simple } \\
\text { Payback }\end{array}$ & $\begin{array}{l}\text { First Year } \\
\text { Cash Flow }\end{array}$ & $\begin{array}{l}\text { Change }(a) \\
\text { in LCC }\end{array}$ \\
\hline Portl and & 8.1 & -2.25 & 2 & 6.8 & 37.71 & 1 \\
\hline Spokane & 6.4 & 81.09 & 1 & 6.1 & 116.77 & 1 \\
\hline Kalispell & 6.1 & 123.60 & 1 & 6.8 & 103.57 & 1 \\
\hline
\end{tabular}

(a) From base configuration of $R-11$ in ceiling, $R-7$ in walls, $R-7$ in floor, and single-pane, aluminum sash windows with movable storm windows.

Figures 4.1 through 4.4 contain 1 ife cycle cost curves for upgrading each component of the building envelope. Insulation investments are shown in Figures 4.1 through 4.3 for both prototype manufactured homes in all three locations. Investments in upgraded window types, because of their peculiar nature, are illustrated separately in Figure 4.4 .

As expected, investments in higher thermal integrity levels result in higher life cycle savings in the colder climates than in the warmer climates. A1so as expected, investments in ECOs for double-section manufactured homes result in higher life cycle savings than in single-section homes due to their larger size and associated higher heating and cooling loads. More interesting, however, are the indications of the relative effectiveness of upgrades to each component. Recall that the base levels are $R-11$ in the ceiling, $R-7$ in the walls and floor, and single pane windows plus movable storm windows in all cases. The curves in Figures 4.1 through 4.3 represent life cycle costs of upgrades beyond those levels. For different base levels, the correct curve for a particular component may be visualized by shifting the origin to pass through that base.

For both prototypes and all climate zones, investment in an optimal floor usually affords the maximum reduction in life cycle cost, at a comparable or lower initial investment compared to the roof and walls. This result is partially due to the fact that floor insulation in manufactured homes is typically not flat as is ceiling insulation. Normally, the floor insulation 


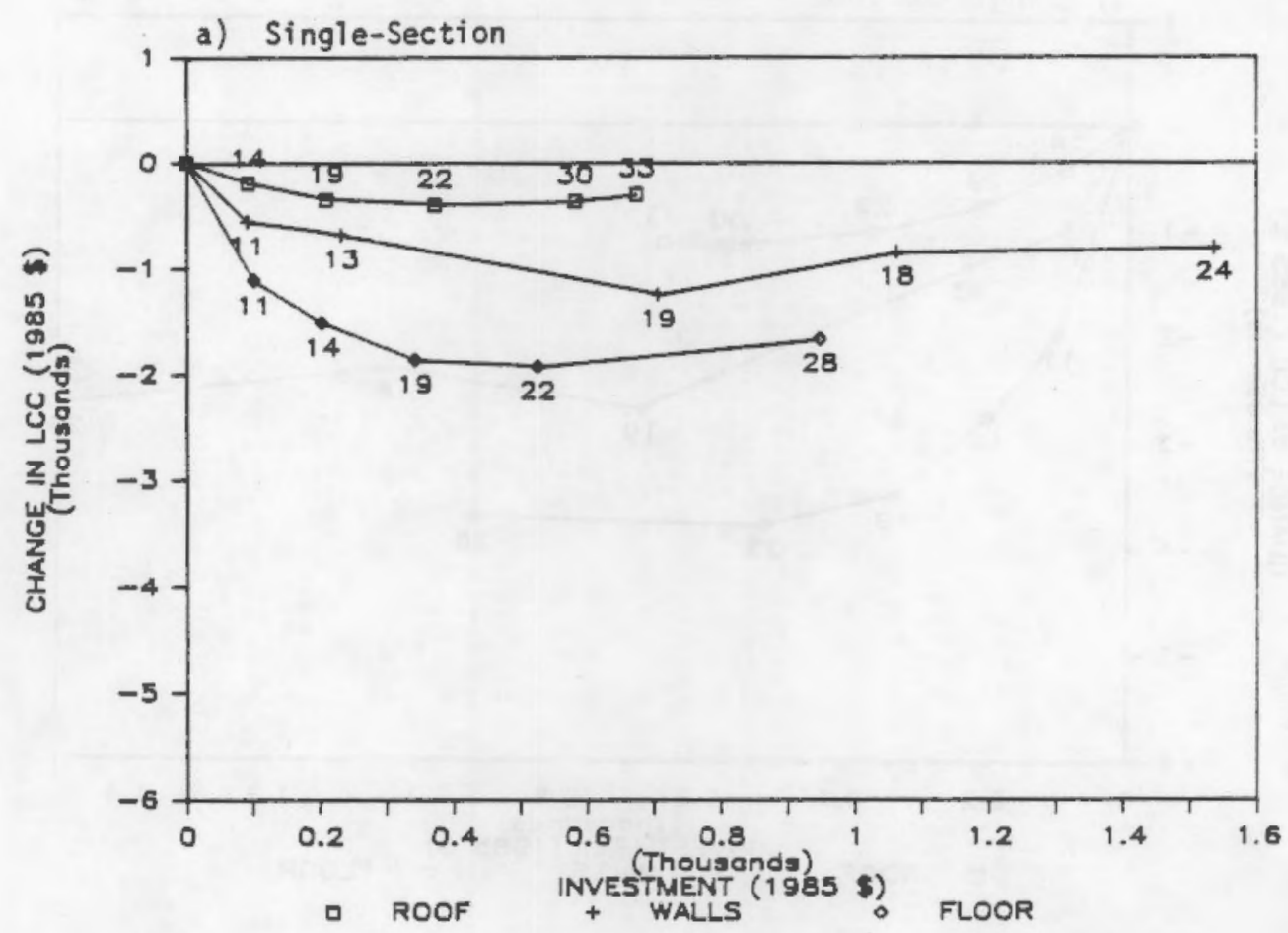

b) Double-Section

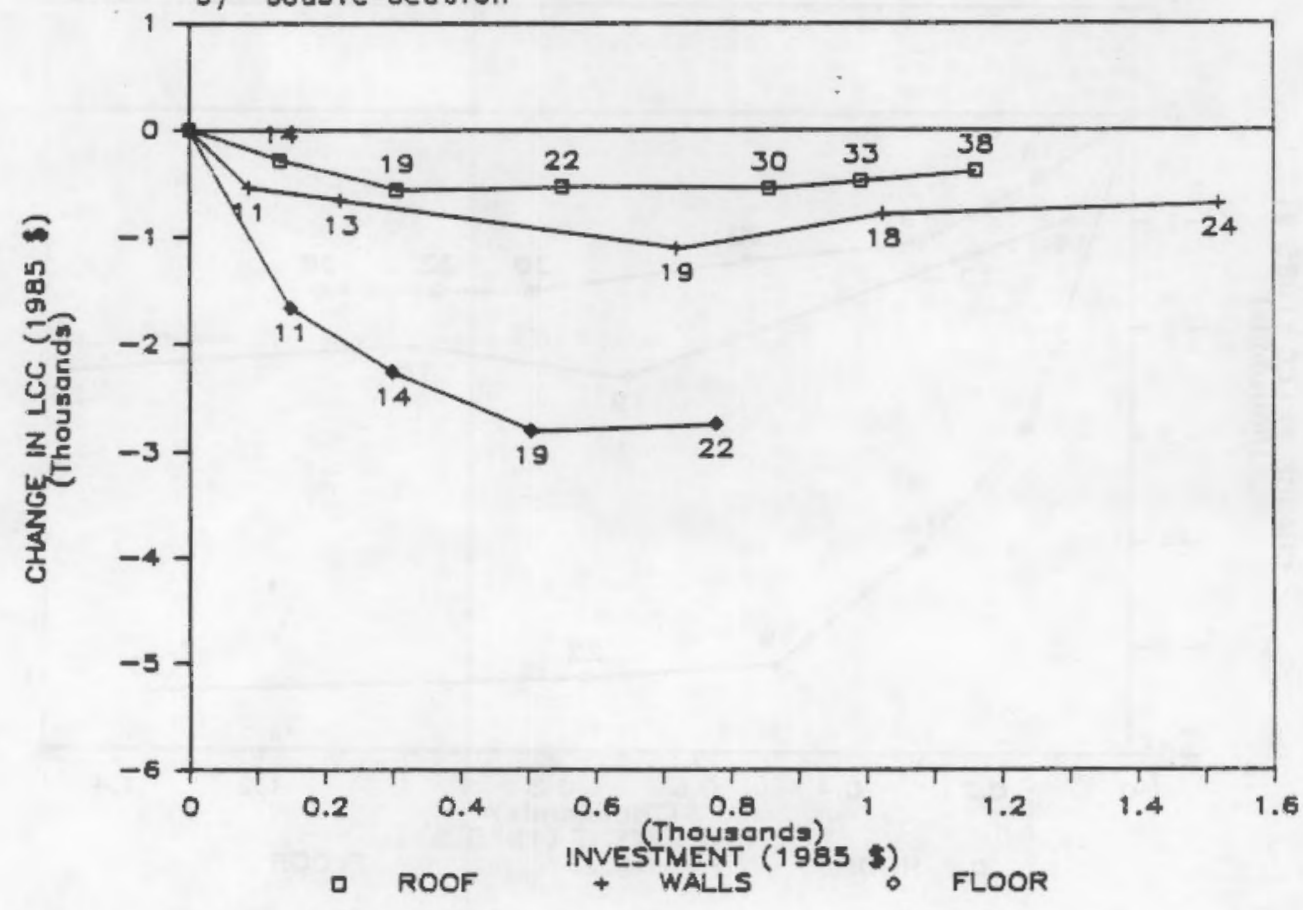

FIGURE 4.1. Change in Life Cycle cost Due to Purchase of Insulation Upgrades - Portland 

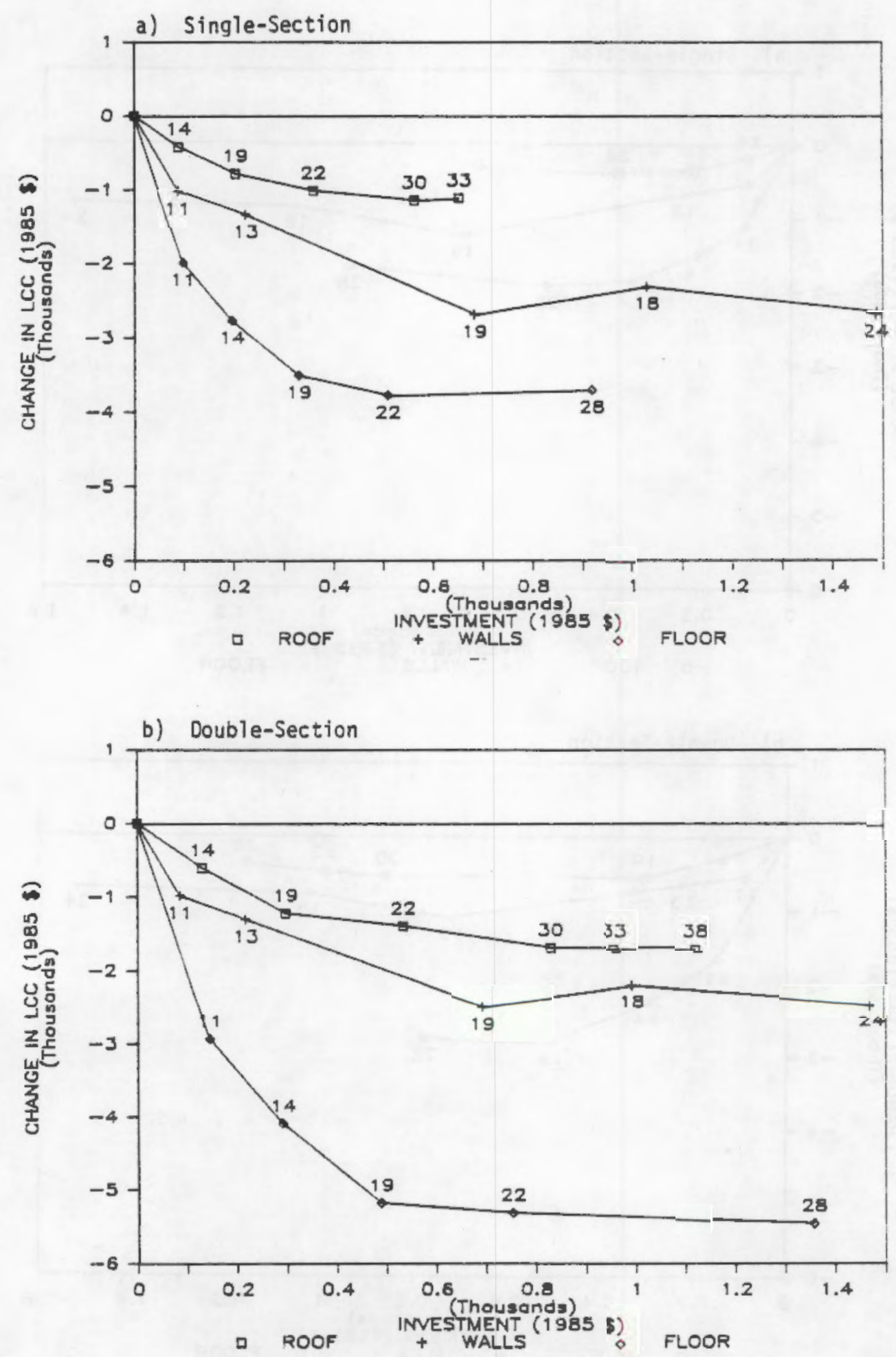

FIGURE 4.2. Change in Life Cycle Cost Due to Purchase of Insulation Upgrades - Spokane 

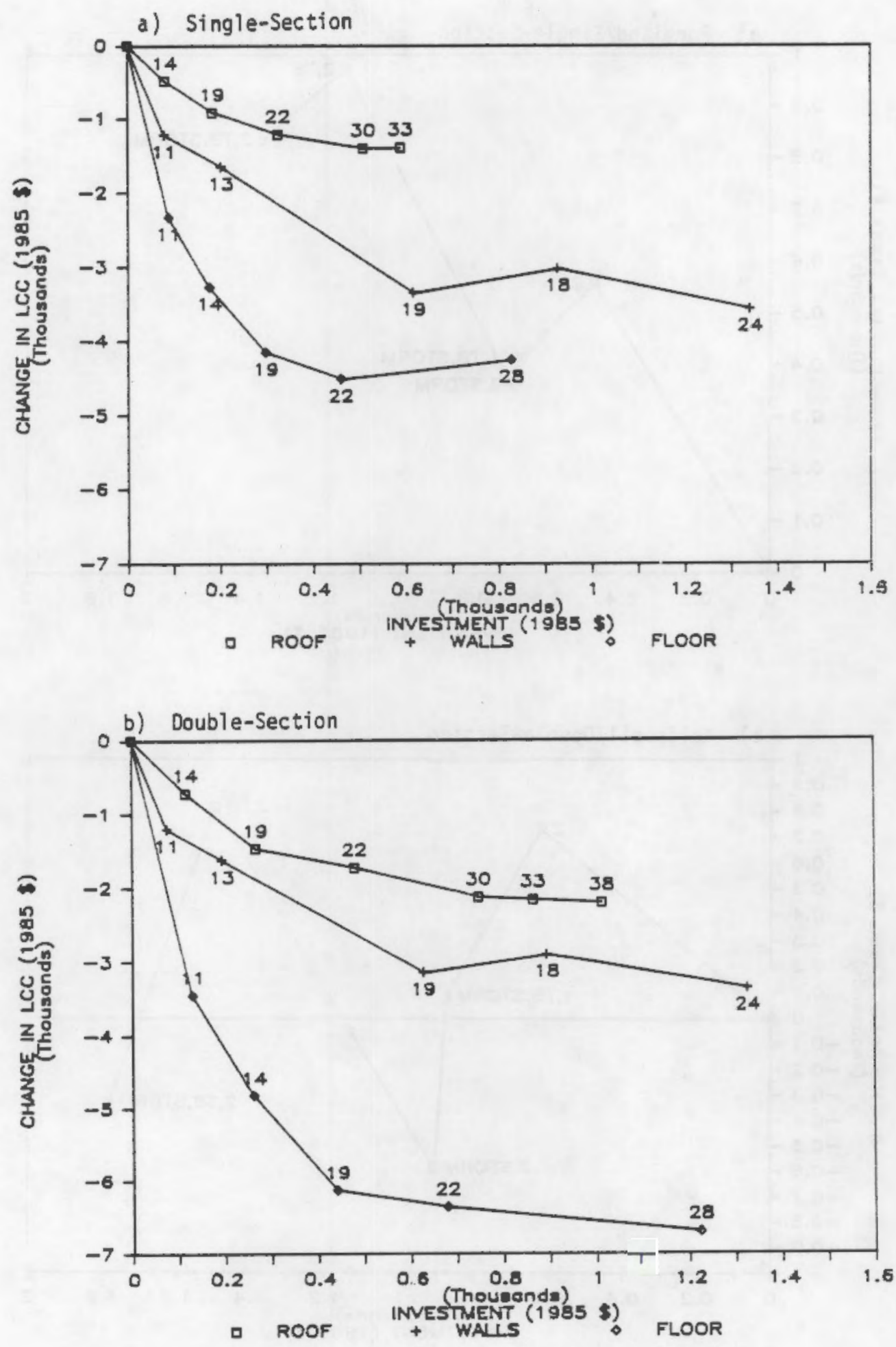

FIGURE 4.3. Change in Life Cycle cost Due to Purchase of Insulation Upgrades - Kalispell 


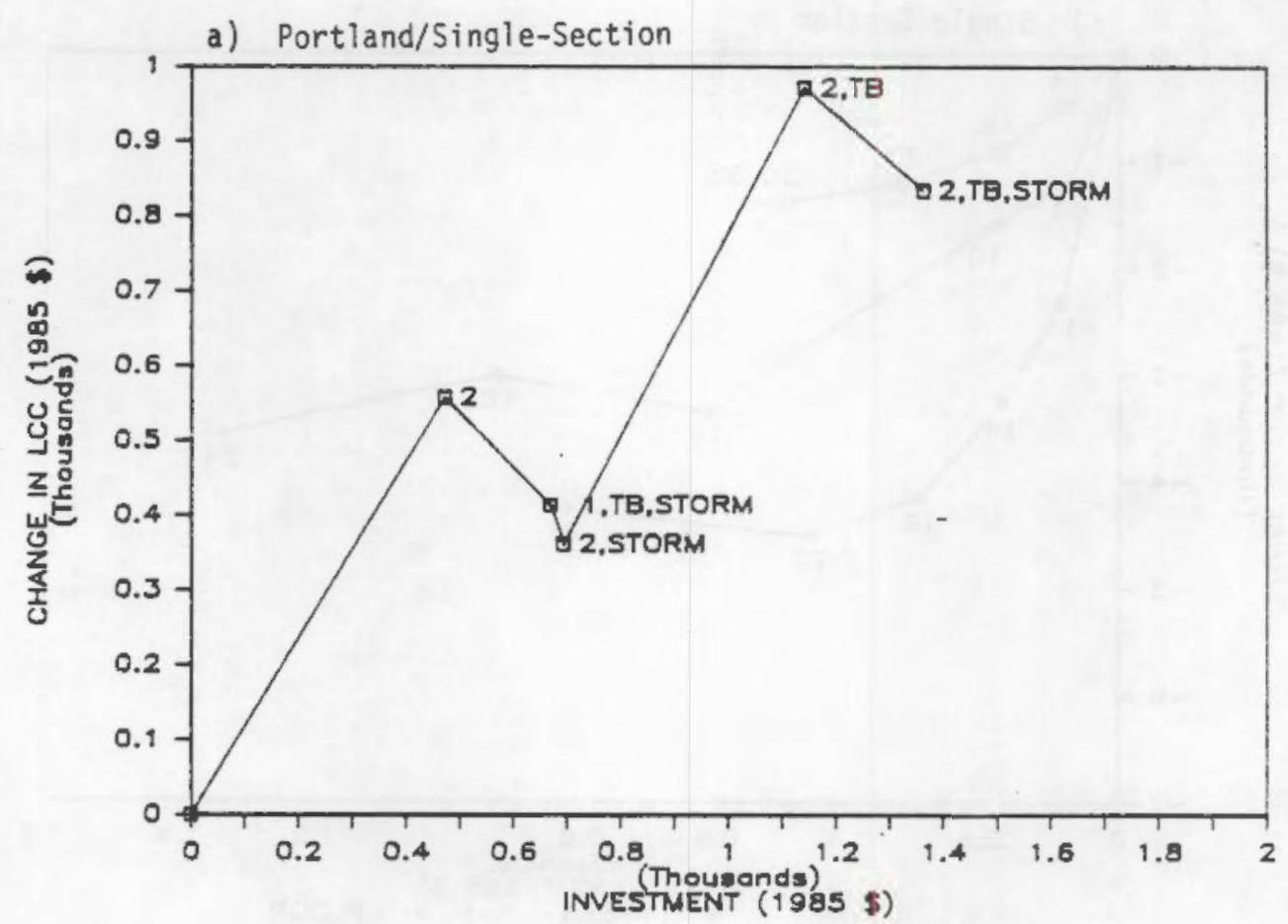

b) Kal ispe11/Double-Section

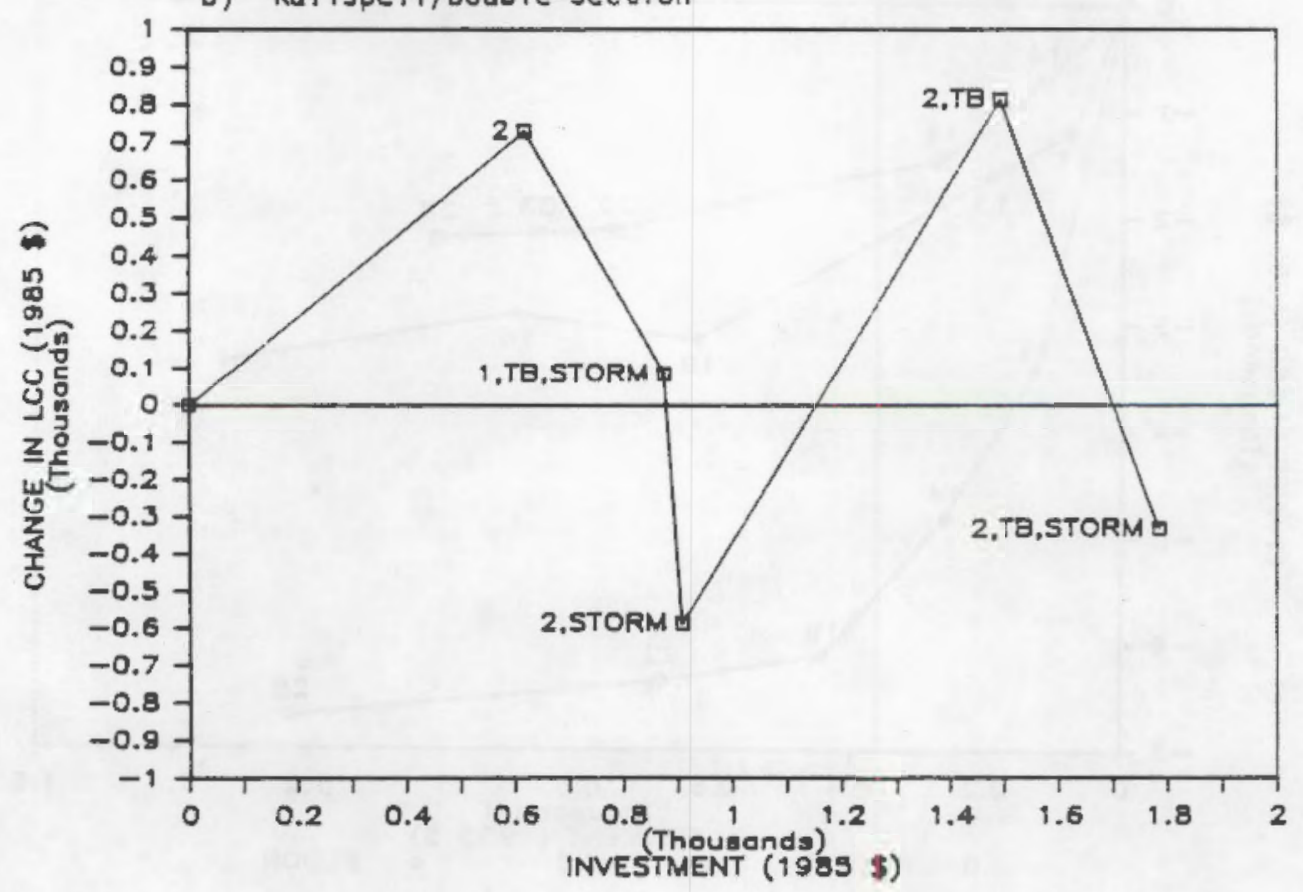

FIGURE 4.4. Change in Life Cycle Cost Due to Purchase of Window Upgrades 
batts are curved around ductwork. This results in the floor insulation having more surface area, and thus higher heating and cooling loads per square foot of envelope than the roof or walls.

Thus the results indicate that a consumer with limited funds for purchasing energy conserving options should prefer the floor upgrade (over the assumed base) in all situations. For single-section homes, the wall upgrade is usually the second most effective option, probably because there is more wall area than roof area. Double-section homes, having a higher ratio of roof to wall area, show similar behavior, though not as pronounced.

It is interesting to note that investments in insulation upgrades did not in any case result in increased life cycle cost to the consumer under this economic scenario. Even the purchase of the most expensive insulation upgrade analyzed does not result in a dramatic increase in life cycle cost over the most effective option. These "flattened" 1 ife cycle cost curves are an indication of the sensitivity of the life cycle cost to economic inputs. Very little change in either the value of energy savings or total cost is necessary to affect the selection of an optimal combination.

An unusual relationship between first cost and life cycle savings of windows is evident in Figure 4.4. Obviously, paying more for windows does not consistently result in energy savings over the option of next lower cost. The trends noticed on these curves are very similar for both prototypes and all climate zones, so only two examples are shown. Single-pane glass (or possibly double-pane in colder regions) mounted in aluminum sash with movable storm windows obviously ranks as the preferred glazing option.

\subsubsection{Sensitivity to Economic Inputs}

The "flatness" of the curves in Figures 4.1 through 4.3 justifies an examination of the sensitivity of the minimum life cycle cost criterion to possible uncertainties in the assumed economic parameters. Table 4.9 ists three additional economic scenarios, labeled $B, C$, and $D$, along with the one discussed above, labeled A. All scenarios involve identical assumptions with the exceptions of discount rate and tax rate. 
TABLE 4.9. Economic Parameters Used in Sensitivity Comparisons

\begin{tabular}{|c|c|c|c|c|}
\hline Parameter & A & B & C & $\mathrm{D}$ \\
\hline Useful life of home (years) & 30 & 30 & 30 & 30 \\
\hline Length of mortgage (years) & 12 & 12 & 12 & 12 \\
\hline Interest rate on mortgage $(\%)$ & 16 & 16 & 16 & 16 \\
\hline Down payment required $(\%)$ & 17 & 17 & 17 & 17 \\
\hline Annual inflation rate $(\%)$ & 5 & 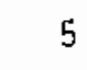 & 5 & J \\
\hline Annual discount rate (real) $(\%)$ & 3 & 3 & 10 & 10 \\
\hline Marginal tax rate $(\%)$ & 20 & 0 & 20 & \\
\hline Heating equipment efficiency $(\%)$ & 100 & 100 & 100 & 100 \\
\hline Cooling equipment efficiency $(\%)$ & 220 & 220 & 220 & 220 \\
\hline
\end{tabular}

In order to account for the fact that many homeowners have very short-term preferences, a real discount rate of $10 \%$ is included (scenarios $C$ and $D$ ). This rate requires a return on investment roughly equivalent to that of buying down the mortgage principal. Because some consumers are either unable or unwilling to take advantage of tax deductions for interest paid on the mortgage, scenarios were included ( $B$ and $D$ ) which assume a marginal tax rate of $0 \%$. Packages with the minimum life cycle cost to the consumer under these economic scenarios are shown in Table 4.10. Remember that scenario A contains the original assumptions.

The preferred combination under each scenario was evaluated for its shortterm economic performance. Table 4.11 shows the simple payback period, first year cash flow, and year in which cash flows become positive for each case.

Several abservations are possible from Tables 4.10 and 4.11 . First, from Table 4.10, the minimum life cycle cost combination is quite sensitive to the selected discount rate. Scenarios $A$ and $C$, which are identical except for the discount rate, show significant differences in the packages which afford the greatest savings to the consumer, especially in the colder locations. Scenarios $B$ and $D$, also identical except for discount rates, show similar 
TABLE 4.10. Preferred Envelope Packages For Various Economic Scenarios

\begin{tabular}{|c|c|c|c|}
\hline City & Scenario & Single-Wide & Double-wide \\
\hline \multirow[t]{4}{*}{ Portland } & A & $22-19-22-1$, storm $(a)$ & 19-19-19-1, Storm (a) \\
\hline & B & 22-19-22-1, St orm & 19-19-19-1, Storm \\
\hline & c & 19-19-19-1, Storri & 19-11-19-1, Storm \\
\hline & D & 19-11-19-1, Storm & 19-11-19-1, Storm \\
\hline \multirow[t]{4}{*}{ Spokane } & A & $30-19-22-2$, storm & 30-19-28-1, Storm \\
\hline & B & $30-19-22-1$, Storm & $30-19-28-1$, Storm \\
\hline & c & 22-19-22-1, Storm & $19-19-19-1$, storm \\
\hline & D & $22-19-22-1$, Storm & 19-19-19-1, Storm \\
\hline \multirow[t]{4}{*}{ KaTispell } & A & $30-24-22-2$, storm & $38-24-28-2$, storm \\
\hline & B & $30-24-22-2$, storm & $38-? 4-28-2$, storm \\
\hline & c & 30-19-22-1, Storm & $30-19-22-1$, Storm \\
\hline & 0 & 22-19-22-1, Storm & $30-19-19-1$, storm \\
\hline
\end{tabular}

(a) The first three terms refer to the nominal insulation R-values of the ceiling, walls, and floor, respectively. The fourth term refers to the window type: number of panes, plus movable storm windows.

behavior. Second, comparing scenario $A$ with $B$, and scenario $C$ with $D$, the effect of tax deductions for interest payments is apparent in some cases, though somewhat less significant.

From Table 4.11 , it is evident that the $10 \%$ discount rate results in more favorable packages from a payback perspective. First year cash flows also tend to be higher. Neglect of tax benefits, except where the preferred package changes due to the neglect, adversely affects cash flows.

4.5.4 Summary and Conclusions

These analyses have presented the economic impacts of enveiope ECOs from the perspective of the manufactured home buyer in the Northwest. To the extent the economic assumptions are correct, the most cost effective conbinations of 
TABLE 4.11. Payback Period (years), First Year Cash Flow, and Year in Which Cash Flow Becomes Positive of Optimum Packages
Based on Minimum Life Cycle Cost

\begin{tabular}{|c|c|c|c|c|c|c|c|}
\hline \multirow{2}{*}{\multicolumn{2}{|c|}{ City/Scenario }} & \multicolumn{3}{|c|}{ Single-wide } & \multicolumn{3}{|c|}{ Double-Wide } \\
\hline & & \multirow{2}{*}{$\frac{\text { Payback }}{8.1}$} & \multirow{2}{*}{$\begin{array}{l}\text { First Year } \\
\text { Cash Flow } \\
\$-2.25\end{array}$} & \multirow{2}{*}{$\begin{array}{l}\text { Yr CF } \\
\text { Pos. } \\
2\end{array}$} & \multirow{2}{*}{$\frac{\text { Payback }}{6.8}$} & \multirow{2}{*}{$\begin{array}{l}\text { First Year } \\
\text { Cash Flow } \\
\$ 37.71\end{array}$} & \multirow{2}{*}{$\begin{array}{l}\text { Yr CF } \\
\text { Pos. } \\
\frac{1}{1}\end{array}$} \\
\hline Portland & $A$ & & & & & & \\
\hline & $B$ & 8.1 & -44.80 & 5 & 6.8 & 2.92 & 2 \\
\hline & C & 7.1 & 22.93 & 1 & 5.0 & 70.03 & 1 \\
\hline & $\Pi$ & 5.1 & 22.12 & 1 & 5.0 & 46.16 & 1 \\
\hline \multirow[t]{4}{*}{ Spokane } & A & 6.4 & 81.09 & 1 & 5.1 & 116.77 & 1 \\
\hline & $B$ & 5.0 & 90.11 & 1 & 5.1 & 40.19 & 1 \\
\hline & C & 4.6 & 149.13 & 1 & 3.9 & 207.90 & 1 \\
\hline & 0 & 4.6 & 107.92 & 1 & 3.9 & 168.55 & 1 \\
\hline \multirow[t]{4}{*}{ Kalispell } & A & 6.1 & 123.60 & 1 & 6.8 & 103.57 & 1 \\
\hline & $B$ & 6.1 & 46.27 & 1 & 6.8 & -15.16 & 2 \\
\hline & $\mathrm{C}$ & 3.9 & 213.57 & 1 & 4.0 & 262.81 & 1 \\
\hline & 0 & 3.6 & 184.83 & 1 & 3.7 & 226.08 & 1 \\
\hline
\end{tabular}

(a) From base configuration of $R-11$ in ceiling, $R-7$ in walls, R-7 in floor, and single-pane, aluminum sash windows with movable storm windows.

ceiling, wall, and floor insulation and window type have been identified. The results are intended to convey an understanding of prospective homeowners' probable reactions to various energy efficiency investment opportunities from an economic perspective. They do not imply optimal configurations from a societal or regional perspective.

It is recognized that these results may appear to differ somewhat from those obtained in other studies on the same or similar subjects. (9) The differences do not necessarily imply disagreement, though they may. Results of studies using different economic criteria and methodologies are not directly 
comparable to these findings. One example is the development of the llodel Conservation Standards, which was based primarily on maximizing energy savings rather than minimizing 1 ife cycle cost.

The analyses have highlighted the economic effectiveness of various envelope upgrades over the approximate minimum features required to meet the HUD MHCSS. Results obtained are dependent on the assumptions regarding economic parameters, the ECO costs, fuel costs and escalation rates, and the model used to estimate energy savings. The minimum life cycle cost results should not necessarily be considered the optimal choices for all situations. Rather, they should be used to understand the gemeral economic impact of ECOs on a "typical" consumer, the relative worth of upgrading different components, and the general effects of economic and climatic environments on economic effectiveness to the consumer. 
REFERENCES AND NOTES FOR SECTION 4.0

1. The data base was developed for PNL under contract to DOE. It is scheduled to be published in mid-1985.

2. D0E-2.1A is a public domain building energy analysis progran prepared for the Department of Energy by Lawrence Berkeley Laboratory.

3. American Society of Heating, Refrigerating, and Air Conditioning Engineers, ASHRAE Handbook - 1981 Fundamentals, Atlanta, Georgia, 1983.

4. It might be argued that the national average sales tax is not applicable in the Northwest. However, since two Northwest states, Oregon and Montana, have no sales taxes, and the others have relatively high taxes, the national average approximates the Northwest as a whole.

5. Robert Snow Means Co., Inc., Building Construction Cost Data 1984, 42nd Annual Edition, Kingston, Massachusetts, 1983.

6. 24 C.F.R. $3280.506(d)$.

7. Department of Energy, Federal Energy Management Progran, Life Cycle Cost Manual, March, 1984.

8. Data Resources, Inc., 11.S. Long-Term Review, Lexington, Massachusetts, Fa11, 1984.

9. Howard Gates, Optimum Thermal Insulation for llanufactured Homes, prepared for the Manufactured Housing Institute, September, 1984. 


\subsection{BARRIERS TO INVESTMENT IN EXTRA COST ENERGY CONSERVATION MEASURES}

The objective of this section is to briefly describe barriers to investment by buyers of new manufactured homes in optional energy-efficiency features. The barriers are similar to barriers to increased energy efficiency in general. A recent report by the National Research Council found that access to capital to pay for greater energy efficiency and the consumers' need for consistent and credible information from trusted sources are principal harriers to greater energy efficiency. (1) These two barriers are discussed in this section.

\subsection{FINANCIAL RARRIERS}

The financial aspects of the manufactured home purchase are quite important to consumers. In $1982,85 \%$ of new manufactured homes were financed. (2) lata from 1083 show that the average loan maturity for new single-wide manufactured homes was 11.3 years and for new multiwide homes 12.9 years. (3) The average minimum acceptable down payment in 1983 was ahout $17 \%$ of the manufactured home purchase price.(3) The average interest rate in 1983 was $16 . n 8 \%$. (2) Ruyers of new single-family site huilt homes, on average, enjoy significantly more favorable financing. In August 1983, for example, new site built home buyers paid an average contract interest rate of $12 . n \%$ with a term to maturity of 25.7 years. (4) The lower average income of MH buyers may help expiain these rate differences.

The average loan term and interest rate on the purchase of a new manufactured home are tending to move closer to the comparable figures for site built homes. This tendency is especially true when the manufactured home is placed on a lot owned by the purchaser. Nevertheless, the adverse financing terms manufactured home buyers face plus their generally lower income (Table 2.13) makes the purchase of extra cost features, such as energy-efficiency measures, difficult for many huyers. A 1984 study by Gates for MHI found that the price elasticity of demand (i.e., the ratio of the percentage change in consumption to the percentage change in price) for manufactured homes was a surprising $-2.5 .(5)$ Thus, using national average 198 ? price and sales data, Gates 
estimated that a $1 \%(\$ 197.60)$ increase in average unit price would reduce demand by $2.5 \%$ (5950 units), other factors being constant. Other studies have consistently found the price elasticity of demand for housing in general including rental housing to be approximately -0.7 , and it is not clear whether manufactured home buyers actually differ so much in terms of price elasticities or whether some analytical differences account for the discrepancy. (6) It is also uncertain whether such elasticities would apply to ECO expenditures since such expenditures provide a return on investment.

To a limited extent, the problem of financing extra cost energy-efficiency options in manufactured homes is being alleviated by lenders willing to exceed their normal loan/income guidelines. Some lenders are willing to exceed their normal guidelines because of the expectation that the buyer can apply the money saved on energy bills to debt service. (7) Typically, lending institutions following this practice will allow up to $30 \%$ of a buyer's gross monthly income to apply to their house payment instead of the normal upper Timit of $28 \%$. 8 ) As of August 1984, 9 Northwest lending institutions were offering to allow their normal loan/income guidelines to be exceeded for buyers of energy-efficient homes who are at the normal allowable debt margin. (9) Although most of these lenders probably had in mind site built homes in offering this preferential treatment, many may make it available for manufactured home buyers.

\subsection{INFORMATION BARRIERS}

A second barrier to investment by buyers of new manufactured homes in extra cost energy-efficiency features is the need for credible information and the lack of sufficient buyer knowledge. Buyers need believable, consistent information on the technology of energy efficiency, the cost effectiveness of particular energy-efficiency features, and information on financing desired options. Ideally, the information should come from a source that the consumer feels is objective, trustworthy and competent. In addition, the information should be conveyed in a manner that is noticed by prospective buyers. Finally, the information conveyed must be understandable. A certification or labeling program such as the Super Good Cents program can potentially aid the process of providing the consumer with understandable energy efficiency information. 
Respondents in the RMH survey were asked about the relative believability of energy information from various sources. (10) The highest score was received by local utilities. Eight-seven percent of respondents indicated that they would find energy conservation information distributed by their local utility "very" or "somewhat" believable. Building contractors tied for second with the media at $73 \%$. BPA received a score of $61 \%$. State energy offices received a surprisingly low believability score of $58 \%$. Respondents to the survey were not asked about manufactured home producers or dealers.

Other factors may be important in marketing energy conservation features to MH buyers. One marketing consideration is that manufactured home occupants, on average, have fewer years of formal education than occupants of other single-family detached homes (Table 2.12). There is also limited evidence that manufactured home owners are less likely to seek energy conservation information than site-built home owners. As of mid-1983, only $8 \%$ of Northwest MH occupants reported that they had received an energy audit on their home. (11) The comparable figure for other single-family detached home occupants was 23\%. (11) Additionally, 17\% of DSFDH occupants reported that they had used the federal income tax credit for conservation improvements to their homes; the comparable figure for I'H occupants was $5 \%$ (11) 
REFERENCES AND NOTES FOR SECTION 5.0

1. National Research Council, Energy Use the Human Dimension, Chapter 3, W. H. Freeman and Co, New York, 1984.

2. Business Trend Analysts, Commack, New York, The Mobile Home Industry, April 1984.

3. Manufactured Housing Institute, Arlington, Virginia, Manufactured Home Financing in 1983, May 1984.

4. U.S. Department of Commerce, 1984 Statistical Abstract of the United States, p. 759.

5. Howard Gates, "Price Elasticity of Demand for Manufactured Homes," prepared for the Manufactured Housing Institute, March 7, 1984.

6. J. M. Quigley, "The Production of Housing Services and the Derived Demand for Residential Energy," Rand Journal of Economic5, Vol. 15, No. 4, p. $560,1984$.

7. One of the most widely followed loan/income guidelines is in the Federal Home Loan Mortgage Corporation's Underwriting Guidelines. FHLMC states that the sum of principal interest, hazard insurance, real estate taxes, homeowners association dues, and ground rents should generally not exceed $28 \%$ of the borrower's stable monthly income. The borrower's total monthly debt payments, inciuding installment debts, alimony, and child support payments, should not exceed $36 \%$ of stable monthiy income.

8. Citizens Federal Savings and Loan in Illinois, for example, follows this practice for manufactured homes meeting the Owen Corning Fiberglas Corporation's "Energy Oualified" home criteria (see Section 7.3.3). Automation in Housing and Manufactured Home Dealer, CMN Associates, Inc., Carpinteria, California, p. 12, February 1985.

9. BPA, Report on Uni form Energy Rating System, August 1984.

10. RMH Research, Inc., River Edge, New Jersey, Marketing Environment for Energy Conservation in the Pacific Northwest, prepared for PNL and BPA, p. 109, May 1984 .

11. Louis Harris and Associates, New York, New York, Pacific Northwest Residential Energy Survey, DOE/BP-328, 1984. 
6.0 REVIEW OF SURVEY DATA CONCERNING MANUFACTURED HOME RESIDENT AND DEALER ATTI TUDES TOWARD ENERGY EFFICIENCY OPTIONS

Attitudes and interests are an integral component of the consumer decision process. While they are not directly observable, they to influence the behavior and actions of consumers. Rather than infer what these underlying attitudes are from observed behavior, several survey studies have identified and measured actual consumer attitudes on a variety of topics.

The objective of this section is to review existing surveys and other literature which cover the attitudes of manufactured home buyers and dealers concerning energy, energy use, and energy conservation options. While the primary focus is on attitudes toward energy efficiency, related attitudinal variables of interest will he included and discussed as well.

Recause each of the surveys or studies discussed in this section was conducted independently, their formats, approach and specific questions are not consistent with each other. Therefore, each study will be discussed separately and a summary discussion will he presented at the conclusion of each subsection. Survey tata will he presented in the following subsections:

5.1 Observations drawn from home and options sales data

6.2 Observation drawn from manufactured home consumer attitude survey data

5.3 Observations drawn from dealer attitude survey data.

\subsection{ORSERVATIONS DRAWN FROM HOME AND OPTIONS SALES SURVEY DATA}

This section examines the purchase and shopping behavior of consumers of manufactured homes. The purchase of options related to energy use and future intentions concerning these options are considered. Shopping, huying and siting decision trends are also presented. The data presented are from a 1981 Owens Corning Fiberglas, Inc. conmissioned study conducted by Opinion Research Corporation. 


\subsubsection{The Facts on the Future and How They Stack Up: A Study of Owner Attitudes Toward Manufactured Home Living ${ }^{(2)}$}

This study is similar to surveys conducted in 1969 and 1974 . The questionnaire was mailed to 7500 recent buyers of manufactured homes the week of April 20, 1981. The final response rate of usable questionnaires was $23.5 \%$. One of the study sections analyzed consumer interests in a variety of options available. Selected results are presented in Table 6.1 for options dealing with energy use. The data was collected from current manufactured home owners, thus it represents buying interest or intent in future manufactured home purchases. Overall, additional insulation was found to be the option most consumers would purchase in their next home. This intention to purchase additional insulation in the next home is probably at least partially a result of the consumers experience with their current home and its thermal performance. OCF also cross evaluated consumer interest in additional insulation by geographic rogion and price of current home. The resutts are presented in Tables 6.2 and 6.3, respectively.

TARL.E. 6.1. Probability of Future Iption Purchase in Next. ilanufactured Home; (2) National Data

\begin{tabular}{|c|c|c|c|c|c|c|}
\hline & $\begin{array}{l}\text { Definitely } \\
\text { Would } \\
\text { Buy (5) } \\
\end{array}$ & $\begin{array}{l}\text { Probably } \\
\text { Would } \\
\text { Buy (4) } \\
\end{array}$ & $\begin{array}{l}\text { Might } \\
\text { Buy (3) }\end{array}$ & $\begin{array}{c}\text { Probably } \\
\text { Would } \\
\text { Not Buy (2) } \\
\end{array}$ & $\begin{array}{l}\text { Definitely } \\
\text { Would } \\
\text { Not Buy (1) } \\
\end{array}$ & Mean \\
\hline Nore Insulation & $56.3 \%$ & 19.38 & $9.7 \%$ & $3.5 \%$ & $3.5 \%$ & 4.3 \\
\hline Central Air Conditioning & 49.6 & 13.4 & 9.5 & 5.7 & 13.7 & 3.9 \\
\hline $\begin{array}{l}\text { Large Capacity } \\
\text { water Heater }\end{array}$ & 41.4 & 19.1 & 13.8 & 7.7 & 8.7 & 3.8 \\
\hline Higher Quality Windows & 35.1 & 22.4 & 19.1 & 7.0 & 8.7 & 3.7 \\
\hline Better Ceiling Materials & 32.5 & 22.8 & 21.5 & 8.2 & 5.8 & 3.7 \\
\hline Foam Sheathing insulation & 24.8 & 17.8 & 24.4 & 10.3 & 12.4 & 3.4 \\
\hline Better Quality Furnace & 23.7 & 14.3 & 14.2 & 9.9 & 26.6 & 3.0 \\
\hline Fireplace & 22.7 & 11.7 & 17.4 & 10.6 & 29.0 & 2.9 \\
\hline $\begin{array}{l}\text { Orywall Painted and } \\
\text { Textured }\end{array}$ & 20.1 & 14.0 & 20.6 & 12.9 & 23.0 & 2.9 \\
\hline All Electric Home & 24.0 & 7.0 & 9.4 & 11.3 & 39.3 & 2.6 \\
\hline
\end{tabular}

Questionnaire scale range:

Definitely would buy $=5$ to definitely would not buy $=i$. 
TABLE 6.2. Probability of Buying More Insulation in Next Manyfactured Home Purchased by Owens-Corning Fiberglas Regions $(2)$

\begin{tabular}{|c|c|c|c|c|c|c|c|c|}
\hline & Total & East & $\begin{array}{c}\text { South } \\
\text { West }\end{array}$ & Central & $\begin{array}{c}\text { North } \\
\text { Central } \\
\end{array}$ & $\begin{array}{c}\text { South } \\
\text { East }\end{array}$ & $\begin{array}{l}\text { North } \\
\text { West }\end{array}$ & Pacitic \\
\hline Detinitely would buy & 56.38 & $52.9 \%$ & $58.1 \%$ & 53.08 & 55.58 & $59.1 \%$ & 57.48 & 52.18 \\
\hline Probably would buy & 19.3 & 23.5 & 20.2 & 18.9 & 22.2 & 16.7 & 16.7 & 21.1 \\
\hline wiqht buy & 9.7 & 11.8 & 7.8 & 12.9 & 11.1 & 10.7 & 13.0 & 9.5 \\
\hline Probably would not buy & 3.5 & -- & 3.4 & 2.3 & 5.6 & 1.9 & 5.5 & 5.3 \\
\hline Definitely would not buy & 3.5 & -- & 3.0 & 5.1 & -- & 2.8 & 3.7 & 5.0 \\
\hline No answer & 7.7 & 11.8 & 7.5 & 7.8 & 5.6 & 8.8 & 3.7 & 6.9 \\
\hline Averaqe & $\begin{array}{r}100.0 \% \\
4.32\end{array}$ & $\begin{array}{r}100.08 \\
4.47\end{array}$ & $\begin{array}{r}100.09 \\
4.37\end{array}$ & $\begin{array}{r}100.0 \% \\
4.22\end{array}$ & $\begin{array}{r}100.0 \% \\
4.35\end{array}$ & $\begin{array}{r}100.09 \\
4.40\end{array}$ & $\begin{array}{r}100.0 \% \\
4.23\end{array}$ & $\begin{array}{r}100.0 \% \\
4.18\end{array}$ \\
\hline & $\begin{array}{c}1 \\
\text { Datinitely } \\
\text { would Not } \\
\text { Guy }\end{array}$ & & $\begin{array}{l}2 \\
\text { Probably } \\
\text { Would Not } \\
\text { Buy }\end{array}$ & & $\begin{array}{c}3 \\
\text { Mi aht } \\
\text { Buy }\end{array}$ & $\begin{array}{l}4 \\
\text { Probably } \\
\text { would } \\
\text { Buy }\end{array}$ & & $\begin{array}{c}5 \\
\text { Definitely } \\
\text { would } \\
\text { Suy }\end{array}$ \\
\hline
\end{tabular}

TARLE 6.3. Probability of Ruying More Insulation in Next Manufactured Home by Price and Width of Current Home; (2) National Data

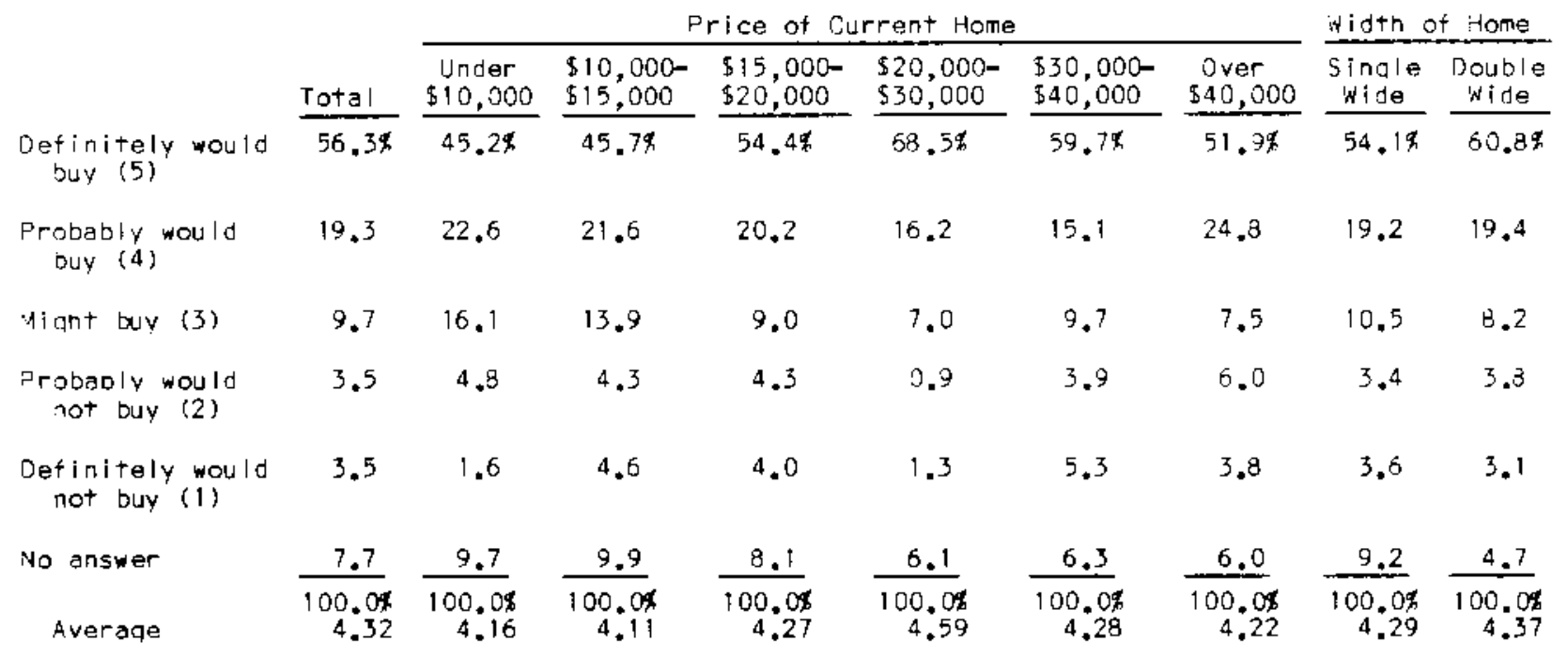

Consumer intentions across geographic and price categories are fairly clear and surprisingly consistent. More insulation and other energy related options are viewed quite favorably in terms of a future purchase across geographic and home price defined market segments. These consumer attitudes are in part due to the consumers experience and satisfaction level with their 
current homes. Satisfaction levels of selected attributes or options of the consumers current home are presented in Table 6.4 .

With scores ranging from 4 (extremely satisfied) to 1 (not at all satisfied), satisfaction with current insulation scored a mean of 2.6 ; between only somewhat to very satisfied. This level of satisfaction suggests a potentially strong motivation for future purchases of insulation or other energy conservation options.

The survey also collects information on the respondent's buying and shopping patterns. This information was compared to 1974 survey results. The data is shown in Tahles $6.5,6.6$, and 6.7. While the data presented in these tables is nominal, there is no evidence to suggest that the Northwest region is significantly different than the rest of the country in these respects. The numher of manufactured home hrands considered and dealers shopped has remained

TABLE 6.4. Satisfaction Levels with Selected Attributes and Options of Current Manufactured Home; (?) National Data

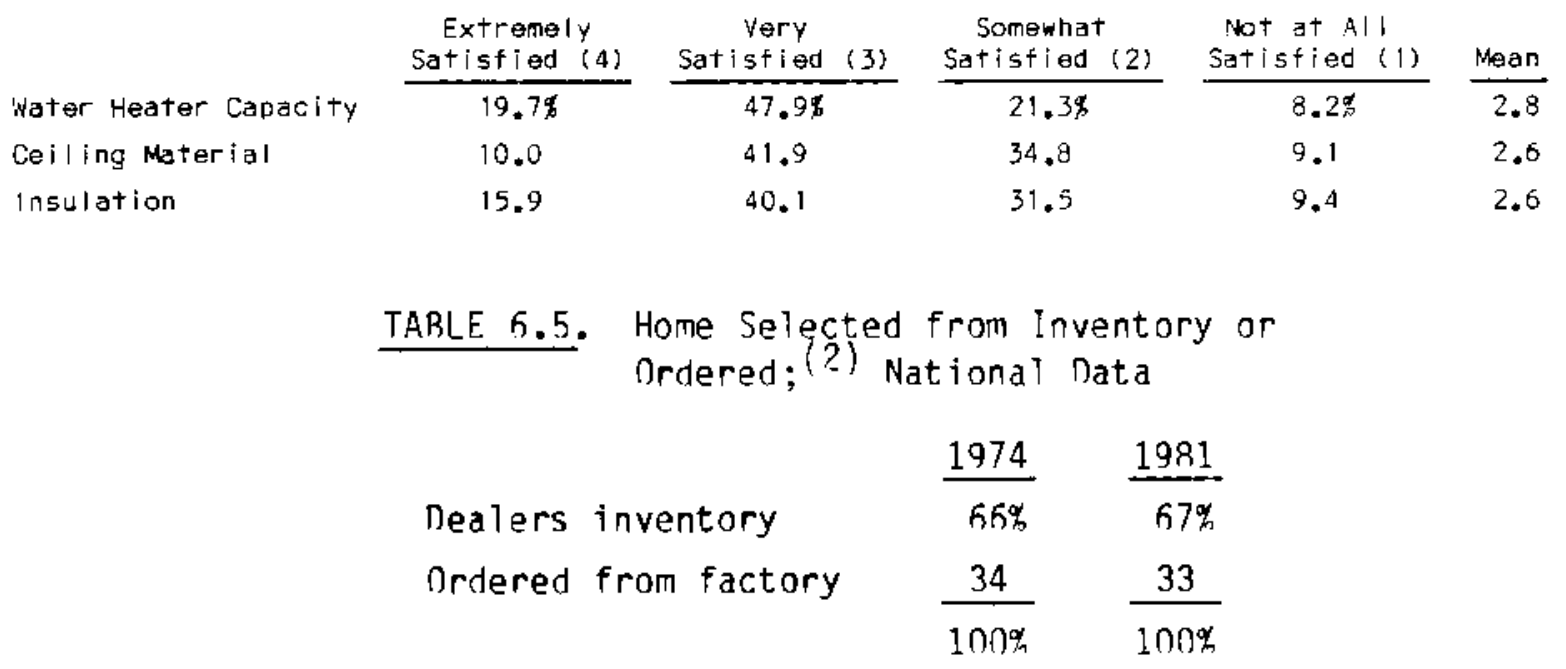

TARLE 6.6. Number of MH Brands Considered and Dealers Shopped; ${ }^{2)}$ National Data

$\begin{array}{lll}\text { Average Number Brands Considered } & \frac{1974}{2.6} & \frac{1981}{2.6} \\ \text { Average Number of nealers Shopped } & 4.2 & 4.2\end{array}$




\section{TABLE 6.7. Information Source Consumers Used to \\ Locate Dealers; ${ }^{(2)}$ National Data}

Driving around

Friend or relative

Newspaper advertisement

Another MH owner

Radio or TV advertisement

Yellow Pages

MH show

$\begin{array}{ccc}\frac{1974}{51 \%} & & \frac{1981}{55 \%} \\ 27 & & 22 \\ 11 & 8 \\ 8 & 7 \\ 6 & 6 \\ 3 & 4 \\ 2 & 2\end{array}$

essentially unchanged. And, as of yet, advertising does not appear to have played a major role in consumer shopping patterns. Ruying patterns are basically unchanged as well, with most homes purchased off the dealer's lot. These patterns are relevant considerations in designing an appropriate marketing plan for energy-efficient manufactured homes in terms of targets for such a program. Because such a large percentage of manufactured homes are sold from dealer stock (Table 6.5), the dealer seems to he a potential target for marketing efforts.

For those consumers who decide to purchase a manufactured home, Tables 6.9 and 6.9 indicate the widths of homes purchased and where they are sited. Two interesting notes are 1) 14-foot wide homes have all but replaced 12-foot wide homes over the past 7 years in terms of consumer purchases and 2) more homes are being sited on private property which directly offsets the reduction in number of homes sited in parks.

\subsubsection{Observations Concerning MH Consumer Attitudes Toward ECO Purchase}

- Manufactured home consumers exhibit fairly high levels of overall satisfaction with the current manufactured home, and their overall living situation.

- Manufactured home consumers base their future purchase intentions in part upon their current situation. 
TABLE 6.8. Manufactured Home Size; (2) National Data

$\begin{array}{lcc}12 \mathrm{ft} \text { wide } & \frac{1974}{46 \%} & \frac{1981}{5 \%} \\ 14 \mathrm{ft} \text { wide } & 21 & 63 \\ \text { Double wide }(24 \mathrm{ft}) & 31 & 21 \\ \text { Double wide }(28 \mathrm{ft}) & -- & 6 \\ \text { Other } & \frac{2}{100 \%} & \frac{5}{100 \%}\end{array}$

TABLE 6.9. Location of Manufactured Home as Sited; (2)
National Data

$\begin{array}{lcc}\text { MH park } & \frac{1974}{57 \%} & \frac{1981}{47 \%} \\ \text { MH subdivision development } & 8 & 8 \\ \text { Private property } & \frac{35}{100 \%} & \frac{\Delta 5}{100 \%}\end{array}$

- If intentions are implemented, one would expect to see an increase in the demand for energy-saving options in manufactured homes.

- The larger question is why didn't consumers purchase energy efficient options in their current home, and how can the decision to purchase such options be influenced for future new home purchases? Secondly, do the purchasers of more recently bujlt MHs exhibit the same intentions as those who purchased 5 years ago?

6.2 OBSERVATIONS FROH EXISTING CONSUMIER ATTITUDE SURVEY DATA

This section deals specifically with manufactured home consumer attitudes concerning energy and energy efficiency. Individual study findings are presented and a composite discussion of implications is presented in subsection 6.2 .6 . 
6.2.1 Manufactured Homes: The Market Facts, Important Answers from Owners of Manufactured Homes About Themselves and Their Homes (5)

This study was conducted by National Family Opinion, Inc. in 1982, and was sponsored by Foremost Insurance Company. Foremost is the nation's largest insurer of manufactured homes. It commissioned the study to obtain a demographic and attitudinal profile of manufactured home consumers. The sample of gnon manufactured home owners was stratified by geography, population density, age, income and household size. The response rate was $79 \%$ (or 7011 ) including responses from all states except Hawai and Alaska. There were 631 responses from the Northwest or $9 \%$ of the total sample. The hreakrown hy state was:

\begin{tabular}{lc} 
& Responses \\
\cline { 2 - 2 } Washington & 243 \\
Oregon & 247 \\
Montana & 89 \\
I daho & $\frac{52}{631}$
\end{tabular}

While most of the survey concerned demographic variables, some general attitirlinal characteristics were included. These are presented in Tables 6.1n, 6.11, and 6.12. This data were not broken down hy gengraphic region, thus, the data presented is at the national level.

TABLE 6.10. Perceived Construction Quality of Manufactured Homes Today (1982) Versus Five Years Ago (1977); (5) National Data

\begin{tabular}{lc}
\cline { 2 - 2 } Much better today & $33 \%$ \\
Somewhat better today & $31 \%$ \\
No difference & $10 \%$ \\
Somewhat worse today & $20 \%$ \\
Much worse today & $\frac{6 \%}{100 \%}$ \\
Numher Responding & $673 ?$
\end{tabular}


TABLE 6.11. Major Advantages of Living in a Manufactured Home as Perceived by Current Owners; ${ }^{(5)}$ National Data

\begin{tabular}{lc} 
& Percent (a) \\
\cline { 2 - 2 } Less upkeep inside and outside & $42 \%$ \\
Less expensive to huy & 31 \\
Compact/space well utilized/cozy & $2 ?$ \\
Less expensive to maintain/energy efficient & 22 \\
Economical/less expensive & 16 \\
Movability & 16 \\
Furnished/instant house & 7 \\
Low/no taxes & 7 \\
Fellowship/activities/neighbors & 6 \\
Convenient & 4 \\
Private/quiet & 4 \\
$\quad$ Number Responding & 5308
\end{tabular}

(a) Total exceeds 1 no due to muttiple responses.

TARLE 6.1\%. Satisfaction with "Manufactured Home living in General; (5) National Data

\begin{tabular}{|c|c|c|}
\hline Level of Satisfaction & $\begin{array}{c}1979 \\
\text { Percent }\end{array}$ & $\begin{array}{c}198 ? \\
\text { Percent }\end{array}$ \\
\hline Very satisfied & $60 \%$ & $60 \%$ \\
\hline Somewhat satisfied & 26 & 30 \\
\hline Somewhat dissatisfied & 9 & 7 \\
\hline Very dissatisfied & 5 & 3 \\
\hline Total Percentage & 100 & 100 \\
\hline Number Responding & 4292 & 6964 \\
\hline
\end{tabular}

Table 6.12 indicates that overall satisfaction with living in a manufactured home is quite high ( $90 \%$ at least somewhat satisfied). Two contributing factors to this high level of overall satisfaction are perceived construction quality (Table 6.10) and the perceived advantages of living in a manufactured 
home (Table 6.11). Sixty-four percent of respondents felt that construction had improved over the past five years. Construction improvements include structural upgrades, such as 2 in. $x 6$ in. walls, greater insulation levels and multiple-pane windows. These perceived structural or construction improvements, which include energy use characteristics, are likely to contribute to the owners evaluation of the advantages to living in a manufactured home (Table 6.11) and his overall satisfaction with the home (Table 6.12). It is not clear how better construction contributes to less upkeep, hut there is a direct link between a home's construction characteristics and its energy use. Given this relationship, and the consumers overall satisfaction level, the ranking of energy efficiency by only $22 \%$ of the respondents as a "major advantage of a manufactured home" seems low. The percentage may he a result of the owners experience with his current home and intentions to upgrade thermal characteristics of the next home, as discussed in Section 6.1.?. Consumers may also perceive that manufactured homes are less energy efficient than site huilt homes, or less energy efficient than they could potentially he.

6.2.? Rarriers to Greater Sales Growth, An Investigation of Consumer Shelter

This study was performed by the Opinion Research Corporation for OwensCorning Fiberglas Corporation. Perceptions and attitudes of manufactured home owners, other single family detached home owners and renters toward manufactured homes were surveyed at the national level. Not surprisingly, manufactured home dwellers were far more positive in their overall attitude toward manufactured homes than other respondents. A psychographic (attitures, interests, opinions (AIO's) and lifestyle) profile of manufactured home owners was also developed. This information is potentially useful in targeting desired market segments within the manufactured home market. While the study was conducted in 1978, the results are still of some interest as there do not seem to he any major attitudinal changes in this consumer group when comparing this study's results with those of more recent studies.

In this study, attributes were measured in terms of their importance to consumers in their home huying decision, and in terms of their association with a particular type of residence. Importance was rated on an 11-point scale which ranged from -5 (not important) to +5 (very important). Consumer 
attitudes toward selected home attributes are presented in Table 6.13. While manufactured home owners are fairly consistent with occupants of OSFDH in terms of their attitudes toward efficiency, they seem to attach a slightly greater importance to insulation and heating/cooling costs than the other occupant groups.

It is clear from Table 6.14 that manufactured home owners attach great importance to energy and energy use considerations in their homes. They also perceive their home to be relatively energy efficient. (7) This result is not surprising if manufactured home consumers purchase homes with options that are consistent with their beliefs about important home characteristics.

The last considerations drawn from this study are the psychographic (attitudes, interests, opinions and lifestyles) differences among the three residence groups under study. These differences are presented in Table 6.15. The importance of this type of information is that it aids market segmentation and implementation of more effective marketing programs directed toward psychographically-identified consumer groups.

From data presented in Table 5.15, one can conclude that manufactured home owners are somewhat more independent, energy conscious and "homebody-ish" than the other groups home owners. This type of information is useful in developing themes, media mixes, promotional activities and other marketing program

TARLE 6.13. Average Importance Ratings hy Groups of Energy Efficiency Considerations; ${ }^{(7)}$ National Data

\begin{tabular}{|c|c|c|c|}
\hline & MH Owners & OSFDH Owner & $\begin{array}{r}\text { OSFDH } \\
\text { Renters } \\
\end{array}$ \\
\hline Be well insulated & 4.7 & 4.4 & 4.4 \\
\hline $\begin{array}{l}\text { Have moderate heating } \\
\text { and cooling costs }\end{array}$ & 4.? & 3.9 & 3.9 \\
\hline Re energy efficient & $4 . ?$ & $4 . ?$ & 4.0 \\
\hline
\end{tabular}

Rating scale: -5 not important to +5 , very important. 
TABLE 6.14. Perceptions of Energy Efficiency in Manufactured Homes; (7)
Nationa? Data

MH Owners who Perceive the Following

Attributes to be Important in Their Home: Percent

"Be an energy-efficient home"

Agree strongly

Agree somewhat

$56.3 \%$

No opinion

29.8

Disagree somewhat

Disagree strongly

1.7

9.3

3.0

"Be well insulated"

Agree strongly

Agree somewhat

No opinion

Disagree somewhat

Disagree strongly

$54.3 \%$

30.8

2.7

7.6

a.6

"Have moderate heating and cooling costs"

Agree strongly

Agree somewhat

No opinion

Disagree somewhat

Disagree strongly

$61.3 \%$

?.7. 3

1.3

4.3

5.3

details. Proper identification of consumers and their attitudes can result in more effective motivational appeals.

\subsubsection{Facts on the Future and How They Stack Up: A Study of Owner Attitudes Toward llanufactured Home Living ${ }^{(2)}$}

Owens-Corning Fiberglas commissioned Opinion Research Corporation to conduct this study on the Manufactured Home buyer in April, 1981. While the most important portion of this study deals with the purchase, and intent to purchase energy-related options (discussed in Section 6.1.2), the study also contains some general attitudinal variables which are presented in Table 6.16 .

The results of this study seem somewhat inconsistent with those found in the Foremost study discussed in Subsection 6.2.1. While the OCF study reports a substantial (11\%) decline in overall satisfaction (Table 6.16), the Foremost study shows a small increase in satisfaction. This may be partially explained 
TABLE 6.15. Psychographic Segmentation of Residence Owner Types: (7) National Data

$\%$ of Respondents Agreeing with Statement

Psychographic Statement

1. I take a great deal of pride in my home.

2. I make every effort to conserve energy around the home.

3. I furnish my home for comfort, not style.

$71.268 .2 \quad 66.4$

4. I would rather spend money on a house than on a car.

$63.3 \quad 73.3 \quad 51.6$

5. I am more independent than most people.

$57.5 \quad 50.5 \quad 55.0$

6. I like to work around the house.

$55.9 \quad 5.3 .2 \quad 42.5$

7. I am a homebody.

$54.0 \quad 50.1 \quad 43.4$

8. Five years from now, the family income will probably be a lot higher than it is now.

$\begin{array}{lll}47.0 & 19.8 \quad 54.3\end{array}$

9. Our family income is high enough to satisfy nearly all our important desires.

$\begin{array}{lll}47.0 & 43.5 & 28.3\end{array}$

10. When making important family decisions, consideration of the children should come first.

11. I do not think houses are well built today.

12. I must admit I really don't like household chores.

$40.8 \quad 45.2 \quad 46.1$

$31.8 \quad 24.4 \quad 30.6$

$25.2 \quad 23.4 \quad 26.0$

13. I like to wait and see how other people like $\quad \begin{array}{llll}17.5 & 16.8 & 14.5\end{array}$ new things before I try them.

14. I would rather live in an apartment than a house.

$1.7 \quad 2.0 \quad 16.4$

Sample size.

in that the Foremost study was done over a period of only 3 years and the OCF study was over a 7 year period, and thus, involved older manufactured homes to compare to newer manufactured homes. 
TABLE 6.16. Overall Satisfaction with Manufactured Home Living; (2) National Data

$\begin{array}{lcc}\text { Extremely or very satisfied } & \frac{1974}{72 \%} & \frac{1981}{64 \%} \\ \text { Somewhat satisfied } & 20 & 26 \\ \text { Not too or not at all satisfied } & 8 & 10 \\ & 100 \% & 100 \%\end{array}$

The data presented in Tables 6.17 and 6.18 can impact rarketing program considerations in a number of ways. The planned tenure of the consumer in the current home (Table 6.17) will affect the realization of net savings beyond the payback period for energy-efficiency options. Tenure decisions will need to be considered as the program is developed, especially if life-cycle cost schedules are developed as sales tools. The data presented in Table 6.17 indicate that the older the home owner, the longer he/she plans to live in the current home. It is interesting that even the younger owners plan to live in the current home at least five years. Marketing programs should consider tenure decisions and their effects on energy efficient home upgrades in teris of paybacks and ife

TABLE 6.17. Planned Tenure in Current Manufactured Home; (2) National Data

\begin{tabular}{|c|c|c|c|c|c|c|}
\hline \multirow[b]{2}{*}{$\begin{array}{c}\text { Number of } \\
\text { year }\end{array}$} & \multirow[b]{2}{*}{ Total } & \multicolumn{5}{|c|}{ Respondent Age } \\
\hline & & $\begin{array}{c}\text { Under } \\
25 \\
\end{array}$ & $25-34$ & $35-44$ & $45-54$ & $\begin{array}{l}55 \text { and } \\
\text { Over }\end{array}$ \\
\hline 1 & $3.0 \%$ & $3.2 \%$ & $2.4 \%$ & $2.5 \%$ & $3.4 \%$ & $3.4 \%$ \\
\hline 2 & 4.8 & 8.8 & 6.8 & 2.9 & 3.4 & 2.0 \\
\hline 3 & 7.4 & 16.6 & 8.7 & 5.4 & 6.8 & 1.6 \\
\hline 4 & 5.4 & 7.4 & 9.1 & 4.6 & 2.1 & 2.2 \\
\hline 5 & 28.5 & 42.1 & $40 . ?$ & 27.1 & 17.3 & 14.9 \\
\hline Indefinitely & 45.8 & 19.4 & 29.8 & 55.0 & 62.4 & 68.0 \\
\hline No answer & 5.1 & 2.5 & 3.0 & 2.5 & 4.6 & 7.9 \\
\hline & $100.0 \%$ & $100.0 \%$ & $100.0 \%$ & $100.0 \%$ & $100.0 \%$ & $100.0 \%$ \\
\hline $\begin{array}{l}\text { Average } \\
\text { Number of } \\
\text { Years }\end{array}$ & 10.1 & 7.3 & 8.5 & 11.0 & 11.6 & 12.5 \\
\hline
\end{tabular}


TABLE 6.18. Why Manufactured Home Living is Chosen;(2) National Data

$\begin{array}{lcc} & \frac{1974}{73 \%} & \frac{1981}{78 \%} \\ \text { More economical than other housing types } & 64 & 68 \\ \text { Wanted to own rather than rent } & 48 & 31 \\ \text { Less maintenance } & 36 & 32 \\ \text { Mobility, can relocate home } & 21 & 18 \\ \text { Bought as retirement home } & 18 & 13 \\ \text { Convenient location } & 4 & 21 \\ \text { Immediate need/no other type available } & 3 & 3 \\ \text { Rought for vacation home } & \end{array}$

cycle costs. Certification programs may in fact encourage investment in energy efficiency, even for short tenure purchases, if the program can successfully convince consumers that their investment can be recovered at the time of home resale with the help of the homes certificate of thermal integrity.

Table 6.18 shows the major reasons consumers select manufactured homes over alternative residence types. This information is also a valuable input ts the development of an effective marketing plan targeted toward manufactured home buyers. (The factor "less maintenance" is generally meant to include the cost of operating the home, including energy costs.) "The three rost frequently mentioned reasons for choosing a manufactured home--price, ownership and lower maintenance--show no significant change over time (1974). Of special note, however, is the dranatic rise in the "availability" category--4\% in 1974 , $21 \%$ in 1981."(2) This increase is consistent with the finding that most manufactured homes are purchased off the dealers lot (Table 6.5). If this purchase trend is true, the focus of marketing efforts would be most effectively directed at manufactured home dealers, as they are the individuals who order the homes to be built.

\subsubsection{Pacific Northwest Residential Energy Survey (PNWRES) ${ }^{(4)}$}

The PNWRES study was conducted in 1983 using a stratified sample. During the period May 27, 1983 to September 4, 1983, in-person interviews were completed with 4703 households in the sample. The completion rate for the survey, i.e., the ratio of completed interviews to sample drawn, was $77.4 \%$ (8) The 
survey included households in all residence types, and covered several aspects of energy use including attitudes toward energy and energy consumption. The results presented in Table 6.19 are only from residents and/or owners of manufactured homes. There were 653 respondents in this residence category. (4) It is important to note that these respondents currently live in manufactured housing, and that market conditions for manufactured housing and energy may have significantly changed since the homeowners purchased their home. These changes will affect the respondents' answers.

Table 6.19 presents the results of attitudinal questions directly related to energy costs and availability. It is interesting that $78.2 \%$ of manufactured home respondents felt that the cost of energy was moderately to very serious while only $12.6 \%$ of these respondents felt that energy scarcity was a moderate or very serious problem. Clearly, these respondents believe that there is no energy supply problem and that energy cost (prices) are the more serious concern. This perception is an important consideration for developing a marketing plan for energy-efficient manufactured homes. The theme or appeal must be consistent with target consumer attitudes and beliefs. The appeal to "conservation" is probably not as effective as simply "saving money" or "economy" given these consumers attitude toward energy supply and energy cost. The term conservation connotes a potential scarcity of supply. Because they feel there is ample supply, manufactured home households probably see no apparent reason to "conserve" to simply save energy. However, given their price sensitivity and

TABLE 6.19. Manufactured Home Dccupants' Attitudes Toward
Energy Cost and Scarcity; 4$)$ Northwest Data

\begin{tabular}{lcc} 
Is This Subject: & $\begin{array}{c}\text { Thoughts on the } \\
\text { Cost of Energy } \\
\text { in Your State }\end{array}$ & $\begin{array}{c}\text { Thoughts on the } \\
\text { Scarcity of Energy } \\
\text { in Your State }\end{array}$ \\
\cline { 3 - 4 } Not serious & $5.7 \%$ & $59.7 \%$ \\
Slightly serious & 13.9 & 20.2 \\
Moderately serious & 29.2 & 10.0 \\
Very serious & 49.0 & 2.6 \\
Don't know & 2.1 & 7.5
\end{tabular}


and attitude toward energy cost, an appeal to "saving money" would make more sense to these consumers and perhaps result in greater interest in energy conservation equipment.

Two other attitudinal variables were examined which support the notion that manufactured home occupants are most interested in economizing or saving money. Both questions deal with price and conservation relationships. Attitudinal responses are presented in Table 6.20 .

Seventy-four percent of respondents feel that the main reason to engage in conservation activities is to save money. The level of disagreement with the second statement presented in Table 6.20 suggests that these consumers are willing to pay to receive these money savings. These types of attitudes indicate that energy costs are important and that roughly haif of the respondents are witling to spend money now to save money in the future. This attitude can become important information when designing marketing programs, themes and appeals to motivate behavior.

Manufactured home respondents appear split in terms of believing energy efficiency will require a one-time action change or a longer term behavioral on lifestyle change. Table 6.21 presents these findings. This information can become a significant input to the development of marketing goals and motivating desired actions on the part of the consumer.

Table 6.21 shows that approximately half of the respondents believe that a lifestyle or behavioral change is required to save energy. Specific attitudes

TABLE 6.20. Price-Conservation Relationship Attitudes; (4) Northwest Data

\begin{tabular}{lcc} 
& $\begin{array}{c}\text { The Main Reason to } \\
\text { Conserve Energy } \\
\text { is to Save Money }\end{array}$ & $\begin{array}{c}\text { The Price I Pay for the } \\
\text { Appliance is More } \\
\text { Important than the } \\
\text { Energy Savings }\end{array}$ \\
\cline { 2 - 3 } Strongly agree & $49.5 \%$ & $8.9 \%$ \\
Somewhat agree & 24.5 & 16.2 \\
Undecided & 2.3 & 15.6 \\
Somewhat disagree & 15.8 & 28.9 \\
Strongly disagree & 8.0 & 30.3
\end{tabular}


TABLE 6.21. To Conserve Enough Energy to Make a Difference, in My Bills, I Would Have to Change My Lifestyle; (4) Northwest Data

$\begin{array}{lrr}\text { Strongly agree } & 25.6 \% & 45.7 \% \\ \text { Somewhat agree } & 20.1 & \\ \text { Undecided } & 4.6 & \\ \text { Somewhat disagree } & 25.3 & 49.8 \% \\ \text { Strongly disagree } & 24.5 & \end{array}$

of manufactured home occupants toward behavioral conservation measures that could be taken are presented in Table 6.22. In general, one half of the respondents believe that making these specific behavioral and lifestyle changes is an effective means of conserving energy. These results, together with those shown in Table 6.20 , indicate that manufactured home occupants believe that specific investments and/or behavioral changes to reduce energy consumption and bills would be effective.

By examining particular attitudina? variables by the age of the home which the respondent occupies, interesting trends emerge.(a) Table 6.23 indicates

TABLE 6.22. Attitudes Toward Specific Energy Saving Behaviors; (4) Northwest Data

\begin{tabular}{lcc} 
& $\begin{array}{c}\text { Reducing Water } \\
\text { Temperature Saves } \\
\text { Enough Money to } \\
\text { Make it Worth } \\
\text { Doing }\end{array}$ & $\begin{array}{c}\text { During the Winter, When } \\
\text { No One will be Home } \\
\text { for 2 Hours or Hore } \\
\text { turning down the } \\
\text { (room) Temperature } \\
\text { is Worthwhile }\end{array}$ \\
\cline { 2 - 3 } $\begin{array}{l}\text { Strongly agree } \\
\text { Somewhat agree }\end{array}$ & $31.2 \%$ & $43.6 \%$ \\
Undecided & 21.3 & 19.9 \\
Somewhat disagree & 21.9 & 5.2 \\
Strongly disagree & 13.0 & 15.9 \\
& 12.6 & 15.2
\end{tabular}

(a) The number of respondents in each construction period category is shown in Table 2.9. 
TABLE 6.23. Comfort Level by Age of MH; Northwest Data(4)

"In the winter, I find it difficult to be comfortable when the temperature in my home is set at $68^{\circ} \mathrm{F}$ or less"

\begin{tabular}{|c|c|c|c|c|c|c|c|}
\hline & \multicolumn{7}{|c|}{ MH Construction Date } \\
\hline & $\begin{array}{l}1940- \\
1949 \\
\end{array}$ & $\begin{array}{l}1950- \\
1959 \\
\end{array}$ & $\begin{array}{l}1960- \\
1969\end{array}$ & $\begin{array}{l}1970- \\
1974 \\
\end{array}$ & $\begin{array}{l}1975- \\
1978 \\
\end{array}$ & $\begin{array}{l}1979- \\
1981 \\
\end{array}$ & $\begin{array}{l}1982- \\
1983 \\
\end{array}$ \\
\hline Strongly agree & $0 \%$ & $38.1 \%$ & $39.3 \%$ & $43.6 \%$ & $42.2 \%$ & $36.2 \%$ & $47.6 \%$ \\
\hline Somewhat agree & 0 & 23.8 & 21.3 & 20.9 & 27.2 & 28.6 & 19.1 \\
\hline Indecided & 0 & 4.8 & 3.3 & 1.6 & 1.7 & 1.0 & 4.8 \\
\hline Somewhat disagree & 0 & 9.5 & 24.6 & 22.0 & 15.6 & 21.9 & 28.5 \\
\hline Strongly disagree & 0 & 23.8 & 10.7 & 11.8 & 13.3 & 12.4 & 0 \\
\hline
\end{tabular}

that the newer the home, the more occupants find it difficult to be comfortabie when the temperature is set at $68^{\circ} \mathrm{F}$ or less in the winter. Table 5.24 indicates that occupants of the newest homes believe that it would not be difficuit to make their home more energy efficient. Lastiy, Table 6.25 indicates that occupants of newer homes believe that changing their behavior or lifestyle is not the only way to make a difference in their electricity bill. In other words, there may be specific actions (weatherization or investments) that could be taken to reduce electricity bills. Therefore, occupants of newer homes believe that there are, in fact, ways to make their home (i.e., the structure? more energy efficjent to a greater extent than occupants of older manufactured

TABLE 6.24. Ease of Retrofit by MH Age; Northwest Data (4)

"It is hard for me to make my home more energy efficient"

\begin{tabular}{|c|c|c|c|c|c|c|c|}
\hline & 1949 & 1959 & 1969 & $19 / 4$ & $19 / 8$ & 1981 & 1983 \\
\hline Strongly agree & $0 \%$ & $47.6 \%$ & $32.0 \%$ & 25.8 & $26.0 \%$ & $22.9 \%$ & $14.3 \%$ \\
\hline Somewhat agree & 0 & 23.8 & 19.7 & 28.0 & 21.4 & 23.8 & 19.1 \\
\hline Undecided & 0 & 4.8 & 7.4 & 5.9 & 8.1 & 14.3 & 9.5 \\
\hline Somewhat disagree & 0 & 14.3 & 23.8 & 16.3 & 18.5 & 18.1 & 14.3 \\
\hline Strongly disagree & 0 & 9.5 & 17.2 & 23.7 & 26.0 & 2.1 .0 & 42.9 \\
\hline
\end{tabular}


TABLE 6.25. Lifestyle Changes and Energy Savings by Age of MH;
Northwest Data

"To conserve enough energy to make a difference in my bilis, I would have to change my lifestyle"

Strongly agree

Somewhat agree

Undecided

Somewhat disagree 0

Strongly disagree 0

\begin{tabular}{|c|c|c|c|c|c|c|}
\hline $\begin{array}{l}1940- \\
1949 \\
\end{array}$ & $\begin{array}{l}1950- \\
1959 \\
\end{array}$ & $\begin{array}{l}1960- \\
1969\end{array}$ & $\begin{array}{l}1970- \\
1974\end{array}$ & $\begin{array}{l}1975- \\
1978 \\
\end{array}$ & $\begin{array}{l}1979- \\
1981 \\
\end{array}$ & $\begin{array}{l}1982- \\
1983 \\
\end{array}$ \\
\hline $0 \%$ & $38.1 \%$ & $29.5 \%$ & $24.2 \%$ & $27.2 \%$ & $20.0 \%$ & $19.1 \%$ \\
\hline 0 & 23.8 & 19.7 & 20.4 & 16.8 & 22.0 & 19.1 \\
\hline 0 & 0 & 4.1 & 2.2 & 4.5 & 7.6 & 9.5 \\
\hline 0 & 23.8 & 22.1 & 27.8 & 28.9 & 21.9 & 28.3 \\
\hline 0 & 14.3 & 24.6 & 25.3 & 22.5 & 28.6 & 28.6 \\
\hline
\end{tabular}

homes. This may suggest that since 1975, MHs are not perceived to be as well built as older homes, or that consumers expect greater use of energy saving construction methods in newer homes. A heightened awareness of energy (use and cost) may aiso contribute to these perceptions.

The data presented in Table 6.26 indicate that a large percentage of the MH occupants surveyed were quite satisfied that their current home was as

TABLE 6.26. Energy Efficiency by 1 'MH Age ${ }^{(4)}$

$14 \mathrm{H}$ Construction Date

\begin{tabular}{|c|c|c|c|c|c|c|}
\hline \multicolumn{7}{|c|}{ I4H Construction Date } \\
\hline $\begin{array}{l}1940- \\
1949 \\
\end{array}$ & $\begin{array}{l}1950- \\
1959 \\
\end{array}$ & $\begin{array}{l}1960- \\
1969 \\
\end{array}$ & $\begin{array}{l}1970- \\
1974 \\
\end{array}$ & $\begin{array}{l}1975- \\
1978 \\
\end{array}$ & $\begin{array}{l}1979- \\
1981 \\
\end{array}$ & $\begin{array}{l}1982- \\
1983 \\
\end{array}$ \\
\hline $0 \%$ & $14.3 \%$ & $31.2 \%$ & $31.7 \%$ & $45.1 \%$ & $41.9 \%$ & $33.3 \%$ \\
\hline
\end{tabular}

The home is as

can be

$\begin{array}{llllllll}\text { A little improve- } & 0 & 28.6 & 25.4 & 27.4 & 26.0 & 34.3 & 38.1\end{array}$ ment can be made

Moderate improve- $\begin{array}{lllllll}0 & 23.8 & 15.6 & 22.6 & 19.1 & 16.2 & 19.0\end{array}$

ment can be made

$\begin{array}{llllllll}\text { A lot of improve- } & 0 & 33.3 & 27.1 & 17.7 & 8.1 & 5.7 & 0\end{array}$

ment $c$ an be made

Don't know

0

$\begin{array}{llllll}0 & 1.0 & 1.0 & 1.7 & 1.9 & 9.5\end{array}$


energy efficient as it could be. This attitude seems to peak in occupants of homes built between 1975 and 1978, and then drops for occupants of newer homes. The downward trend indicates that occupants of new homes believe to a lesser extent that their home is as energy efficient as it could be. This finding is consistent with the attitude trends shown in Tables 6.23, 6.24, and 6.25 concerning thermal efficiency of the respondents' current home. Perhaps attitudes of new "H occupants concerning the efficiency of their current home, and the respondents perception of what could he done to improve the home's efficiency contribute to the findings presented in Tabie 6.1 indicating consumer intent to purchase energy savings options to a greater degree in their next home.

The PNWRES data revealed many useful insights into the thinking and motivation of manufactured home households toward energy use and efficiency. In general, the survey respondents were found to exhibit the following characteristics:

- price consciousness

- belief that there is no current energy supply problen

- helief that their home is fairiy energy efficient, but this belief decreases with occupants of newer homes

- helief that there are activities (one time actions or life style changes) that are worth engaging in to save energy and/or money

- tendency to believe that more could be done to newer homes to improve their energy efficiency.

\subsubsection{The Marketing Environment for Energy Conservation in the Pacific Northwest (3) (RMH Study)}

The RMH Study was conducted for PNL and BPA in the fall of 1983 by RMH Research, Inc., of New Jersey. The study was designed to gather "comprehensive information on the factors motivating residential electricity consumers to take energy conservation actions." (3) A total of 2000 telephone interviews were conducted with residents of the Northwest. The sample was stratified to be representative of the Northwest. Specific information collected included 
"attitudes toward, perception of, motivation for and knowledge of energy conservation measures" for all residence types. (3) The information in this section compares attitudes concerning energy use and efficiency of individuals living in manufactured homes with those living in other single family homes. There were 132 manufactured homes and 1522 single-family detached homes in the RMH sample.

The first variable examined is manufactured home residents perceived level of seriousness of the energy situation. Their attitude is compared with that of residents in other single-family detached homes in Table 6.27. While this information indicates that approximately $6 \%$ more manufactured than other single-family home residents perceive the situation to be very serious, about equal numbers of each group perceive the situation to be at least somewhat serious. The percentage of respondents perceiving the situation to be very serious for the entire RMH sample in all housing types was $29.6 \%$. (3) The important point to note is that manufactured home residents are more at the "extremes" in evaluating the energy situation than all other groups of residents by structure type.

A second attitude variable that was measured is whether spending money on energy efficiency improvements or changing one's lifestyle is the preferred method of reducing energy use. The results are presented in Table 6.28. This information indicates that more manufactured home residents would rather change their lifestyle to reduce energy consumption than spend money to do so. This

TABLE 6.27. Perceived Seriousness of the Energy Situation; (3) Northwest Data

\begin{tabular}{lcc} 
& \multicolumn{2}{c}{ Residents of } \\
\cline { 2 - 3 } Very serious & $34.3 \%$ & $\frac{\text { Danufactured Homes }}{28.4 \%}$ \\
Somewhat serious & 43.2 & 52.5 \\
Not very or not & 20.8 & 14.9 \\
at all serious & & \\
No response & 1.7 & 4.2
\end{tabular}


TABLE 6.28. Respondent Choice to Reduce Energy Use; (3) Northwest Data

\begin{tabular}{|c|c|c|}
\hline & Manufactured Homes & OSFDH \\
\hline $\begin{array}{l}\text { Would rather } \\
\text { change life- } \\
\text { style to reduce } \\
\text { energy use }\end{array}$ & $58.0 \%$ & $49.9 \%$ \\
\hline $\begin{array}{l}\text { Would rather spend } \\
\text { money on improve- } \\
\text { ments to reduce } \\
\text { energy use }\end{array}$ & 31.4 & 30.3 \\
\hline $\begin{array}{l}\text { Both, neither, } \\
\text { not sure }\end{array}$ & 10.6 & 19.8 \\
\hline
\end{tabular}

may be due to generally lower incomes with lit occupants (Section 2.0), or simply an expression of preference. The preference toward a lifestyle change to reduce energy consumption is more prominent in manufactured home residents than in other single-family home residents. These results are fairly consistent with the PNHRES data presented in Table 6.21. The PNIRES data indicate that about one-half of the $M H$ respondents feit they would have to change their lifestyle to make a difference in their utility bill and the Ril data indicate a lifestyle or behavior change is their preference in terms of reducing electricity bilis. The implication is that marketing programs promoting low/nocost conservation measures and/or appropriate behavior changes may be effective.

The RMH data also classified or segmented consumers into groups through clustering of psychographic statements from the respondent around three general categories. (3) These categories are:

- Altruistic

- Cynics
-- residents who feel strong social responsibility toward energy conservation

-- people who are doubters or who are skeptical of the value of conservation efforts

- The Disheartened -- Those who feel they have done everything possible to save energy or are totally satisfied with what they have done. 
Manufactured home and other single-family home residents were classified into the above market segments. These segmentation results are presented in Table 6.29.

Manufactured home residents feel to a greater extent that they have done all that they can to make their home energy efficient. This attitude is consistent with the PNWRES and OCF findings that manufactured home residents feel their home, for the most part, is energy efficient and that there is little to be gained by retrofit activities, especially in older homes. nccupants of new homes seem to feel that retrofit may be more worthwhile. The data also indicate that manufactured home residents are less "socially oriented" when it comes to energy efficiency. In other worts, conservation activities would be engaged in for personal or practical rather than altruistic reasons.

These findings help explain manufactured home residents classification into specific prospect groups for conservation investment. The target prospect groups are described hy RMH as: (3)

- First Tier Prospects -- Those who have already completed numerous conservation measures and are most likely to be candidates for future major investments

- Second Tier Prospects -- Those who have already made some investment in conservation measures and are likely to perform considerable weatherization in the future

- Non-Prospects -- Those residents unlikely to take any conservation actions in the future.

TARLE 6.29. Consumer Segmęntation by Attitude Toward Energy Conservation; (3) Northwest Data Segment

Altruistic $\frac{\text { lla nufactured Homes }}{26.9 \%} \frac{\text { DSFDH }}{33.8 \%}$

Cynic

10.5

9.3

Disheartened/Done Everything

2.9 .7

20.9

Not Concerned/Classified

32.9

36.0 
lanufactured home and other single-family detached home resident classification into these prospect groups is shown in Table 6.30 .

It is not surprising, given manufactured home residents' generally favorable attitudes toward energy-efficiency levels of their home, and more negative attitudes toward retrofitting, that over half of $\mathrm{MH}$ residents are classified as nonprospects. The nonprospect classification is further confirmed by examining manufactured home residents' intentions to perform future improvements presented in Table 6.31. An important consideration is that these classifications are for future weatherization or equipment investment, not new home purchases.

It is clear that there are differences between housing type groups that warrant considering them independently in terms of developing effective marketing programs for energy efficiency. And, while structural and other characteristics of the home will affect attitudes and perceptions, several consistent patterns emerged. The major attitudinal findings from the survey data are that manufactured home residents in general:

TARLE 6.30. Resident C.lassification into Prospect Target Groups; (3) Northwest Data

\begin{tabular}{lccc}
\multicolumn{1}{c}{ Prospect Group } & Manufactured Homes & & $\frac{0 S F O H}{20.7 \%}$ \\
\cline { 1 - 2 } First Tier & $12.4 \%$ & $26 \%$ \\
Second Tier & 16.3 & 26.5 \\
Nonprospect & 53.5 & 39.4 \\
Other Not Classified & 17.8 & 13.4
\end{tabular}
TABLE 6.31. Intentions tg Perform Future Improvements to
Save Energy; 3 Northwest Data

\begin{tabular}{|c|c|c|}
\hline Segment & Manufactured Homes & OSFDH \\
\hline Minimal & $51.2 \%$ & $41.7 \%$ \\
\hline Moderate & 21.0 & 31.2 \\
\hline $\mathrm{High}$ & 10.0 & 13.7 \\
\hline No Answer & 17.8 & 13.4 \\
\hline
\end{tabular}


- perceive the energy situation to be "very serious" in greater numbers than other groups of consumers

- prefer lifestyle or behavioral changes to spending money on home improvements to save energy

- are not convinced that retrofitting their current home is of any value in terms of saving energy/money, especially in older homes

- are classified primarily as nonprospects for future weatherization or conservation equipment investments for their current home

- show little intent to engage in conservation measures (for their current home) in the future.

\subsubsection{Sumary of Consumer Attitude Data}

The studies sited previously are both Northwest region specific $(1,3,4,8)$ and national $(2,5,6,7,10,11)$ in scope. Each was conducted independently and at different points in time. However, their results and findings are quite consistent with each other. Fach presents a similar profile of manufactured home owner/occupant consumer attitudes, heliefs, intentions and remographic characteristics which to not appear to vary to any significant degree by geographic region. For this reason, the following discussion is hased upon all of the data presented in Section 6.0 under the assumption that there are no significant differences in geographic groupings of manufactured home consumers in terms of demographics attitudes or intentions.

The typical occupant of manufactured homes is quite satisfied with their home. In general, these residents are very concerned ahout the cost of energy and possibilities for cost reduction through energy efficiency improvements. Except for those in newer homes, occupants generally believe that their current home is energy efficient but that hoth lifestyle or behavioral changes and spending on home improvements or retrofitting can be effective ways of delivering energy/cost reductions. $(2,3,4,5)$ There is however, a fairly large group (about $1 / 3$ of $M H$ occupants) who would prefer to engage in retrofit conservation activities rather than lifestyle changes. To obtain the highest level of market penetration for conservation, targeting both groups with specific programs may be most appropriate. The intent and interest in energy 
conservation is there; what may be lacking is the (sales) promotion and information--the "supply" side of the exchange to instigate consumer activity in this area.

Another possible consideration is to move away from the idea of "conservation" to one of simply "efficiency, money saving or economizing" for these consumers. This would seem to be consistent with the "practical" attitude profile of MH occupants. The cost impact of energy is perceived as serious, $\{4$ ! and manufactured home residents are sensitive to price. 4,9$)$ They see no reason to simply conserve energy for the sake of conservation, hecause these consumers do not believe that there is a shortage of supply. (4) The apparent inconsistency of rising prices in a surplus situation may in fact frustrate consumers and create resistance to conservation programs and the purchase of more energy efficient homes. Thus, repositioning (changing) the conservation idea from saving energy to efficient use may prove more effective at motivating and appealing to this market segment.

A second consideration in terms of advertising or promotion is the source of the information and its perceived credibility (see Section 5.2). The data presented in Table 5.32 indicate the perceived image of various institutions which deal with energy. It appears as if the local utility enjoys the most favorable image and, thus, would he a good and fairly trusted information

$$
\begin{aligned}
& \text { TARLE 6.32. Perceived Images of Energy Institutions (for all } \\
& \text { residence types) }
\end{aligned}
$$

\begin{tabular}{|c|c|c|c|c|}
\hline Perceived Impression & Local Utility & BPA & $\begin{array}{l}\text { Northwest Power } \\
\text { Planning Council }\end{array}$ & $\begin{array}{c}\text { State } \\
\text { Energy Office }\end{array}$ \\
\hline Very favorable & $19 \%$ & $8 \%$ & $6 \%$ & $9 \%$ \\
\hline Somewhat favorable & 54 & 40 & 40 & 51 \\
\hline Not very favorable & 22 & 36 & 33 & 2.6 \\
\hline Not at all favorable & 5 & 16 & 21 & 13 \\
\hline $\begin{aligned} \text { Rase }= & \text { respondents } \\
& \text { familiar } \\
& \text { with each } \\
& \text { organization }\end{aligned}$ & $88 \%$ & $65 \%$ & $40 \%$ & $43 \%$ \\
\hline
\end{tabular}


source. The apparent conflicting market signals of rising prices and a supply surplus, and the consumer frustration mentioned above, may play a role in the formation of perceived images and credibility.

The RMH study is useful in highlighting differences between manufactured home and other single-family home residents. Residents of manufactured homes have somewhat different attitudes on the energy situation, spending on home improvements to save energy, and future purchase and retrofit intentions. (3) This difference suggests that there is justification for a marketing program specifically targeted at the manufactured home consumer to increase awareness and propensity to purchase energy efficient options for their homes. The manufactured home target market segment has been identified by attitude toward energy conservation, (3) further conservation investment prospect, (3) and psychographics. (7) All categories show differences between residents of manufactured houses and other single family detached homes resulting in a distinct and identifiable target market segment.

From these segmentation schemes and the other survey data examined, the following composite characteristics and attitudes from the Northwest and national data seem to describe manufactured home resinents:

- They are concerned ahout the energy situation, especially its cost

- They do not believe there is a current energy supply problem

- They are satisfied with their home and believe it is energy efficient; thus, they are not interested in retrofit activities. As a result, they believe that behavior changes are the best way to reduce energy bills in their current home. These attitudes were found to vary by the age of the current home in the PNWRES data.

- They exhibit positive intention to purchase more energy-savings options in their next home

- They are independent, practical and are "home bodies"

- $60 \%$ plan to live in the home at least 5 years

- They have observable attitudinal and behavioral differences from other single-family home residents. 


\subsection{DEALER/RETAILER ATTITUDE SURVEY DATA}

This section discusses manufactured home dealer attitudes toward energyefficiency and energy-savings options and their sales. Comparisons will be made with consumer attitudes on the same topics. Areas where a difference exists between dealer and consumer attitudes and perceptions represent potential focus points for a marketing program for energy-efficient manufactured homes. Dealer attitudes will be presented in a chronological format and their implications will be discussed in Section 6.3.2. The survey data presented are taken from two surveys conducted by the Owens-Corning Fiberglas Corp. in 1980 and 1981 respectively.

\subsubsection{Dealer and Consumer Attitudes Toward Energy Efficiency}

Owens-Corning Fiberglass conducted two surveys of dealer and consumer attitudes in 1980 and 1981. The first survey was conducted at the 26th Annual Midwest lobile/Modular recreational vehicle show on the 15 th and 16th of August, 1980, in South Bend, Indiana. This sample consisted of 120 consumers and 52 dealers. (10) The second survey was conducted at a manufactured housing show in Sacramento, California in llarch, 1981. This sample included 71 consumers and 30 dealers. (11)

The data presented in Tables 6.33 and 6.34 indicate that consumers across climatic regions express a high level of interest in energy-efficient homes.

\section{TABLE 6.33. Consumer/Dealer Interest in Energy-Efficient Homes}

Consumer: Are you interested in energySacramento $(11)$ efficient 'MH's?

Yes, very much so

Yes, somewhat

No, not at all

Dealer: Are your customers interested in an energy-efficient home?

Yes, very much so

$71.0 \%$

29.0

0.0
Yes, somewhat

No, not at all
$87.0 \%$

13.0

0.0
$82.0 \%$

11.0

7.0 
TABLE 6.34. Interest Intensity in Energy Efficient Manufactured Homes

Consumer: Describe your interest in
energy efficient homes: Sacramento $^{(11)} \quad$ South Bend $(10)$

I would insist on one

$65.0 \% \quad 70.0 \%$

I would like to own one

33.0

22.0

I don't care

2.0

8.0

Dealer: Describe your customers' interest in energy efficient homes:
liore interested than prior years
$94.0 \%$
$90.0 \%$
Less interested than prior years
0.0
4. 0
Express no interest
6.0
6.0

Consurners in the Sacramento study were more interested in energy-efficient homes than those at South Bend. However, Table 6.34 indicates that the intensity of interest in terms of insistence upon an energy efficient home, is greater in South Bend. Dealers in both studies perceive that there is much greater consumer interest in energy efficiency than in the past, but they tend to underestimate the level of this interest as indicated in Table 6.33.

Tables 6.35 and 6.36 deal with consumers willingness to pay for energyefficient options or packages. The consumers expressed attitude is compared with dealers' perception of their consumers' willingness-to-pay attitudes.

TABLE 6.35. Willingness to Pay for an Energy-Efficient MH

Consumer: Would you pay more for an

Sacramento $(11) \quad$ South Bend $(10)$ energy-efficient home?

Yes

No

Dealer: Do your think consumers will

pay more for an energy

efficient home?
Yes

No
$94.0 \%$

6.0

$89.0 \%$

11.0 
TABLE 6.36. Amount Consumers are Willing to Spend for Energy Efficiency

Consumer: If you would pay more, how much more?

$\$ 50$ more yielding $25 \%$ monthly savings

$\$ 1000$ more yielding $30 \%$ monthly savings

$\$ 1500$ more yielding $35 \%$ monthly savings

Dealer: If consumers would pay more, how much more would they pay?

$\$ 500$ more yieiding $25 \%$ monthly savings

$\$ 1000$ more yielding $30 \%$ monthly savings

$\$ 1500$ more yielding $35 \%$ monthly savings
Sacramento(11) South Bend $(10)$

$36.0 \%$

$31.0 \%$

46.0

27.0

18.0

42.0

Dealers in the South Bend survey consistentiy underestimated the amount of money consumers were willing to spend for an energy-efficient home (Table 6.36). This misperception indicates that their current sales/ promotional efforts could be redirected to enable dealers to make the most of consumer interest to increase the market penetration of energy efficient equipment and homes.

Consumers seem to be aware of the cost of buying an energy-efficient horle and seem willing to spend to realize monthly savings. Consurer interest in specific energy-savings features and dealer perceptions of consumer interests were found to be reasonabiy close in rankings, but somewhat different in terms of magnitude. The results in Table 6.37 show these findings. They are available for the South Bend Survey only. Percent totals add to more than $100 \%$ due to multiple responses.

Lastly, the dealers in the South Bend Survey(10) were asked what the advantages are to the dealer in selling energy-efficient homes. Their responses are presented in Table 6.38. If these are in fact the perceived advantages to dealers in selling energy-efficient homes, and if dealers are a target of a marketing program to enhance manufactured homes energy efficiency, these advantages should be stressed as benefits of participation in such a marketing program. 
TABLE 6.37. Interest in Specific Energy Features

South Bend (10)

Consumers: What energy features are you most interested in?

Well insulated

$47.0 \%$

Storm windows and doors

19.0

Energy-efficient heating and air conditioning

17.0

Wood burning fireplace

4.0

Gas heating

3.0

Miscellaneous

10.0

Dealers: What energy features are customers most interested in?

Insulation

$77.0 \%$

Efficient heat and air conditioning

Two-pane storm windows

R-values

6.0

Hood burning fireplace

4.)

Hot water heater

2.0

No answer

6.0

TABLE 6.38. Dealer Perceived Advantages to Selling
Energy-Efficient $\mathrm{MHS}_{\mathrm{S}}(10)$

$\begin{array}{lc}\text { Satisfaction of the consumer } & 40.0 \% \\ \text { Easier to sell } & 15.0 \\ \text { Saves (the consumer) money } & 12.0 \\ \text { Improves dealer reputation } & 10.0 \\ \text { Less (consumer) maintenance } & 4.0 \\ \text { No answer } & 19.0\end{array}$

It is generally believed by other parties (Appendix A) who have implemented marketing programs to promote the sale of energy efficient manufactured homes that dealers are one of the key elements of the consumer purchase process. The evidence in Table 6.39 indicates that dealers do have the ability to influence the purchase decision for energy saving options. The results of a 
TABLE 6.39. Incidence of Energy-Efficient Manufactured Home Purchase Among Buyers Who Receiyed Energy-Efficient Options

Promotions by nealers; $\left.{ }^{2}\right)$ National Data

\begin{tabular}{cccccccc}
\hline Under & $\$ 10,000-$ & $\$ 15,000-$ & $\$ 20,000$ & $\$ 30,000-$ & Pver \\
Yes & $\frac{\text { Total }}{77.8 \%}$ & $\frac{\$ 10,000}{69.6 \%}$ & $\frac{\$ 15,000}{77.2 \%}$ & $\frac{\$ 20,000}{74.7 \%}$ & $\frac{\$ 30,000}{80.0 \%}$ & $\frac{\$ 40,000}{87.2 \%}$ & $\frac{\$ 40,000}{80.0 \%}$ \\
No & $\frac{22.2}{100.0 \%}$ & $\frac{30.4}{100.0 \%}$ & $\frac{22.8}{100.0 \%}$ & $\frac{25.3}{100.0 \%}$ & $\frac{20.0}{100.0 \%}$ & $\frac{12.8}{100.0 \%}$ & $\frac{20.0}{100.0 \%}$
\end{tabular}

1981 survey indicate that over three-quarters of the respondents who purchased an energy-efficient home received dealer promotions on energy-efficient homes, with buyers of higher-priced homes being most receptive. (2) However, dealer incidence of promotion of energy-saving options was low at that time. Table 6.40 indicates that approximately $71 \%$ of dealers did not promote energy efficiency in 198t. Where such promotion does occur, it is most prevalent among the lower-priced homes where consumers were found to be less responsive. 6.3.2 Discussion of the Dealers' Role in the Purchase necision Process

nealers are an important link in the consumer decision process. They can significantly influence the consumer in terms of the decision to purchase energy-efficient options, but the incidence of such promotion was reported to be low. (2) Dealers, for the most part, accurately perceive consumers' (positive) attitudes toward energy efficiency and energy-efficient homes, but tend to underestimate the dollar amount they are willing to spend on energy efficiency. $(10,11)$ Given the dealers' role, influence, perception and potential TABLE 6.40. Incidence of Dealer (2) $\begin{aligned} & \text { Pomotion of Energy-F.fficient } \\ & \text { Mational Data }\end{aligned}$

Price of lobile Home

\begin{tabular}{|c|c|c|c|c|c|c|c|}
\hline & Total & $\begin{array}{c}\text { Under } \\
\$ 10,000 \\
\end{array}$ & $\begin{array}{l}\$ 10,000- \\
\$ 15,000 \\
\end{array}$ & $\begin{array}{l}\$ 15,000- \\
\$ 20,000 \\
\end{array}$ & $\begin{array}{l}\$ 20,000- \\
\$ 30,000\end{array}$ & $\begin{array}{l}\$ 30,000- \\
\$ 40,000 \\
\end{array}$ & $\begin{array}{c}\text { Over } \\
\$ 40,000 \\
\end{array}$ \\
\hline Yes & $29.4 \%$ & $38.3 \%$ & $24.3 \%$ & $28.9 \%$ & $31.5 \%$ & $20.5 \%$ & $15.7 \%$ \\
\hline \multirow[t]{2}{*}{ No } & 70.6 & 61.7 & 75.7 & 71.1 & 68.5 & 79.5 & 84.3 \\
\hline & $100.0 \%$ & $100.0 \%$ & $100.0 \%$ & $100.0 \%$ & $100.0 \%$ & $100.0 \%$ & $100.0 \%$ \\
\hline
\end{tabular}


gains, a marketing program of appropriate incentives and/or sales tools for dealers may be helpful in increasing the market share of energy-efficient manufactured homes, and fill a real and stated consumer need. 
REFERENCES AND NOTES FOR SECTION 6.0

1. Pacific Northwest Laboratories, Survey Data Collected from Manufactured Home Manufacturers in the Pacific Northwest, March 1985.

2. Opinion Research Corp., Princeton, N.J., The Facts on the Future and How they Stack IJp, A Study of Owner Attitudes Toward Manufactured Home Living, prepared for the Owens Corning Fiberglas Corp., Pub. No. 5-MH-11011, January 1982.

3. RMH Research, Inc., The Marketing Environment for Energy Conservation in the Pacific Northwest, prepared for PNL and BPA, May 1984.

4. Louis Harris and Associates, Inc., Pacific Northwest Residential Energy Consumption Survey, Spring 1983, prepared for BPA.

5. National Famity Opinion, Inc., Manufactured Homes: The Market Facts, Important Answers from Owners of Manufactured Homes About Themserves and Their Homes, prepared for Foremost Insurance Company, 1982.

6. Owens-Corning Fiberglas Corp., A Report to the Manufactured Housing Industry: A Survey of Retailer Attitudes on Eneray Ffficiency in the Homes They Buy and Sel1, 1984 .

7. Opinion Research Corp., Princeton, N.J., Rarriers to Greater Sales Growth; An Investigation of Consumer Shelter Decision-llaking as it Impacts the lobile Home Industry, prepared for the Owens Corning Fiberglas Corp., pub. No. 5-P1H-8693A, necember 1978.

8. Louis Harris and Associates, Inc., Pacific Northwest Residential Energy Survey, Field Work and Data Reduction Activities Summary Report, October 24, 1984 .

9. Howard Gates, Price Elasticity of Demand for Manufactured Homes, prepared for MHI, March 7, 1984.

10. Opinion Research Corp., Princeton, N.J., The Energy Efficiency Rarrier, A Follow-up, a Report to the Mobile Home Industry on Dealer and Consumer Attitudes Towards the Energy Efficiency Barrier, prepared for the OwensCorning Fiberglas Corp., Puh. No. 5-MH-10302, January 1981.

11. Opinion Research Corp., Princeton, N.J., The Energy Efficiency Rarrier, A Mild Climate Follow-up, a Comparat ive Geographic Study of Consumer and Dealer Attitudes Towards the Energy-Efficiency Barrier in the Manufactured Home Market, prepared for the Owens-Corning Fiberglas Corp., Pub. No. 5-MIH-10725, July 1981 . 


\subsection{DESIRABLE FEATURES OF A MARKETING PROGRAM TO PROMOTE ENERGY-EFFICIENT NEW MANUFACTURED HOMES}

This section discusses background information, program options, and desirable features for a marketing program implemented by a government agency or a utility to encourage the purchase of energy conservation options (ECOS) on new MHs. The development of a marketing plan appropriate to a given situation is an essential prerequisite to designing effective marketing programs. A marketing plan outlines a general course of action to serve as a basis for individual marketing programs. In this case, the marketing plan should be directed toward the goals of increasing awareness/acceptance of, and propensity to purchase energy conservation measures and equipment for new MHs. The foundation and required inputs to such a marketing plan will be discussed in this section. They include:

7.1 The Generic Structure of a Marketing Plan

7.2 Influence Channels and Their Possible importance to a Marketing Program

7.3 "Lessons Learned" from Others' Experience with Marketing Programs for Promoting Energy-Efficient Manufactured Homes

7.4 Discussion of Marketing Program Options for Implementation by a Government Agency or UtiTity

7.5 The Desirable Features of a Marketing Program for Energy-Efficient Manufactured Homes.

\subsection{THE GENERIC STRUCTURE OF A MARKETING PLAN}

This section has two objectives. First, the purpose and contents of a generic marketing plan will be discussed. The generic marketing plan is appropriate for a firm or organization which is marketing its products or services directly to consumers. The second aspect of this section is to demonstrate how the marketing plan should be adapted to situations when the firm or organization is not selling any product or services directly to consumers, but is, rather, trying to influence the purchase decision process. The latter scenario 
is the case for BPA's efforts to encourage consumers to purchase manufactured homes above the minimum HUD-code thermal requirements.

\section{Marketing Plan Goals}

The purpose of a strategic marketing plan is to systematically organize and direct marketing activities for the accomplishment of measurable, realistic and desirable goals. To this end, the marketing plan consists of strategies (goals), tactics (methods of achieving the goals), and controls to ensure that goals are being met. The overall objective of this planning process is to produce an optimal marketing plan which will bring about the desired change or reaction from its target audience.

The fact that a plan is considered optimal does not, however, guarantee that the desired change will occur. Some types of changes are difficuit to achieve and require a variety of marketing activities appropriate for the type of change (goal) desired. There are four types of changes which may be goals to marketing plans in a given situation. They will be discussed in order of their difficulty to achieve (i.e., from least to most difficult).

Cognitive Change. A marketing plan designed to create a cognitive change is seeking to change levels of awareness, education or knowledge. This type of change is relatively easy to achieve as it does not call for any value, attitudinal or behavioral alterations. If action is required after the cognitive change has been accomplished, then value, attitudinal and behavioral altarations may become obstacles to achieving the desired action (goa1). Hyman and Sheatsley (2) give several reasons why informational campaigns designed to create a cognitive change may fail:

1. "There is a chronic group of know-nothings that are hard to reach no matter what the level or nature of the information."

2. "The likelihood of being exposed to information increases with interest in the issue. If few people are initially interested, few will be exposed."

3. "The likelihood of being exposed to the information increases with the information's compatibility with prior attitudes. People will tend to avoid disagreeable information." 
4. "People evaluate information they are exposed to in light of their own values, attitudes and beliefs. Thus, peop? e emerge with a variety of reactions to the same information."

These constraints point to the need to target an appeal to a specific market segment whose values and attitudes are well understood. In this way, material will be of interest and interpreted in a consistent and desirable manner.

Action Change. This is a second-level change and thus is harder to achieve than a cognitive change. Marketing plans with the goal of action change are attempting to induce persons to take specific actions within a specific period of time. The reason this type of change is more difficult to accomplish is because now, in addition to creating awareness and knowledge, it is desired to have the person (target) take action based upon this new information, which involves costs (time, money, etc.) to the individual. Designers of a marketing plan with action as a goal should seek to provide for a "leastcost" action change by the individual or target market.

Behavioral Changes. White an action change induces a one time response, a behavioral change calls for a permanent modification of one's behavior in particular circumstances. Behavioral changes involve learning new behaviors and habits that occur over time. This type of change is thus much more difficult and takes longer to achieve than either of the two previous change types.

Value Changes. The last category of change, and the most difficult to accomplish, is a change in an individual's values. Because values are few in number, and at the root of our behavior, actions and awareness, they form the foundation of an individual's choice. The appearance of information, actions or behavior that is inconsistent with an individual's value set creates dissonance (strain or stress), and this intruding stimuli is then usually ignored, avoided or rationalized away. Marketing efforts that call for value change are not likely to succeed because their message becomes the intruding stimuli, and are hence, avoided.

Energy conservation marketing plans should concentrate their efforts on the first three goals; cognitive, action or behavioral changes. These goals 
are more likely to be achieved as long as they are induced properly and time expectations are realistic. Examples of each would be:

- Cognitive change - Awareness/knowledge of conservation programs and equipment available.

- Action change - Purchase of an energy-efficiency upgrade package for a new manufactured home.

- Behavior change - Inducing lifestyle or energy use changes, such as taking fewer showers, using fewer appliances or turning the heat down $10^{\circ} \mathrm{F}$ when leaving for work each day.

Value changes should be avoided as they generally produce counter-productive results--generally resistance to any program or measure. With the proper or appropriate goal(s) selected, a marketing plan to achieve them can be developed.

A generic marketing plan will consist of several sections that will vary in terms of importance and detail, depending upon the marketing goal to be reached. In general, a marketing plan is comprised of the following sections. (1)

- Problem or Purpose Statement

- This statement establishes the problem to be solved or the goals to be reached through the implementation of the plan. This step defines the target market to be approached, the goals of the plan in terms of sales volume, market share, revenues, etc. This step provides direction for planning and a control mechanism for measuring the effectiveness of the plan.

- Situation Audit

- This section assesses the current situation the firm finds itself 
in, both internally and externally. Analysis of the current situation and a prediction of future scenarios is included in the audit.

- Situation Evaluation

- With input from the situation audit, an evaluation is made of the internal environment in terms of strengths and weaknesses, and the external environment in terms of opportunities and threats. These areas are identified as they relate to the problem to be solved.

- Alternative larketing Strategies

- This section is a brief description of the broad marketing approaches available to solve the problem at hand. Alternatives should utilize strengths to improve weaknesses and eliminate threats while capitalizing on opportunities that can help solve the problem.

- Recommendations

- This section explains which alternative or combination of alternatives have been selected and why.

- Implementation

- This is a key section which spells out in specifics exactly what is to be done and by whom to put the recommended strategy into action. Product, price, promotion and distribution are all detailed, budgeted, and designed at this point. 
This step would also include proforma profit/loss statements to be used in the control step.

- Control

- Lastly, the program needs to be monitored to be sure that goals are being reached. If goals are not being met, then adjustments in the plan need to be made to allow the program to succeed.

The preceding steps are appropriate for developing a marketing plan for a firm or agency selling a product or service directly to consumers such as BPA selling electricity to utilities or industry. However, when the agency or firm is not directly selling the product to consumers but is, rather, attempting to influence the consumers decision, the marketing plan needs to be modified. This is the case for BPA in terms of promoting energy efficiency in manufactured homes. BPA is, in this case, a non-market participant in the consumer decision. BPA's role in this situation is that of an influencer to the decision. This orientation requires a different approach to the development of an appropriate marketing plan. Important features include: (1)

- Problern Statement

- Goal Setting
- This step is basically the same as in the general case explained above. A clear understanding of the root problem to be solved and a cleariy defined target audience are essential to the program's success. A marketing plan cannot be successfu? if it focuses on symptoms or addresses the wrong problem.

- Once the problen is properiy defined, goals that will help solve the problem need to be established. As discussed above, the goals will be a cognitive, action, behavioral 
or value change on the part of the target audience. The appropriate goal must be selected in terms of effectively solving the problem as stated. The goals must be stated in realistic and measurable terms if they are to be achieved and used for control purposes.

- Target Market Segmentation

- Because the target audience may not be customers of the firm or agency initiating the marketing plan, this step becomes especially important. Identifying the correct target markets allows the marketing effort to focus its attention upon the appropriate group(s), and because it narrows the focus, results in more cost-effective marketing efforts. Target audiences can be identified by a variety of segmentation variables such as demographics, geographics, psychographics (lifestyle, attitudes, etc.), price sensitivity or role in the consumer decision. The variables used to segment the market must result in meaningful groupings of more homogeneous consumers or influences for marketing efforts to be effective. - Consumer Analysis

- Once segments have been identified, the consumers contained within each segment must be analyzed in terms of their characteristics, behavior and 
attitudes. In this way, proper communication and incentive structures can be developed to induce the change(s) desired.

- Influence Channel Analysis

- This step requires the marketer to determine which players in the consumer decision process (influence channels) are most important to the consumer's decision. Examples may be retailer, wholesaler, advertisements, friends, etc. Marketing efforts and incentives $c$ an be focused correctly on the players with the highest impact only after they are identified. (Each of the influence channels in the decision process for energy efficiency enhancements in manufactured homes will be discussed in Section 7.2).

- Marketing Strategy Development - At this. point, alternative marketing approaches can be evaluated in terms of their ability to produce the desired results. Through this process, an overall marketing strategy is developed to reach the desired goals.

- Implementation

- Tactical planning puts the strategy decided upon into action. Specific budgets, media mixes, distribution channels and incentive structures, for example, are designed and put 
into effect. These should also be stated in measurable, realistic terms.

- Control

- Lastiy, monitoring results against desired goals will indicate the effectiveness of the strategy and/or tactics used to achieve the desired goal(s). At this point, adjustments to the plan can be made if results are less than satisfactory.

As the reader can see, the orientation for a government agency or utility implemented marketing program is somewhat different than for the more direct consumer marketing case. Because the initiator is external to the actual market components of the purchase decision, the thrust is on influence channels and incentive structures that do not appear overly important in the general case. The appropriate marketing plan structure is diagrammed in figure 7.1 .

\subsection{INFLUENCE CHANNELS AND THEIR POSSIBLE IMPORTANCE TO A MARKETING PROGRAM}

In Section 7.1, it was noted that a key difference between a marketing plan in the general case and one implemented by a government agency or utility is that the latter two are nonmarket participants in the consumer decision to purchase manufactured housing. Even so, non-market participants purpose is to attempt to influence the purchase decision in a desired direction. The relationship of market and non-market participants is shown in figure 7.2 .

Because of the indirect market role of BPA and its utility customers, marketing activities should focus on both market and nonmarket participants in the consumer decision that will have the greatest influence. While there may be interaction effects between non-market participants, the focus of marketing activities should be on the direct influences upon consumers and their decision making along the product flow, as diagramed in Figure 7.2. An understanding of the role of each channel of influence, and its potentia?, is an appropriate input to development of the marketing pians. 


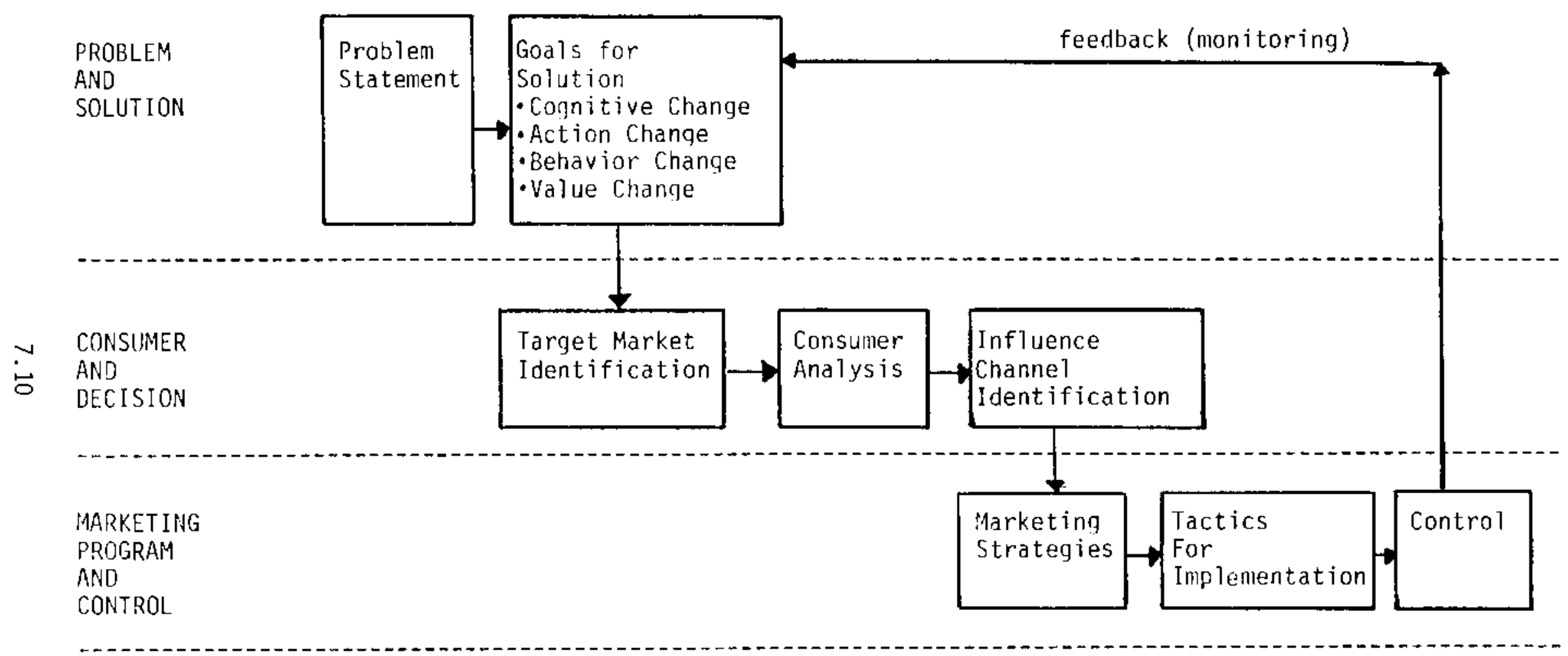

FIGURE 7.1. Three Levels of Marketing Plan Development 


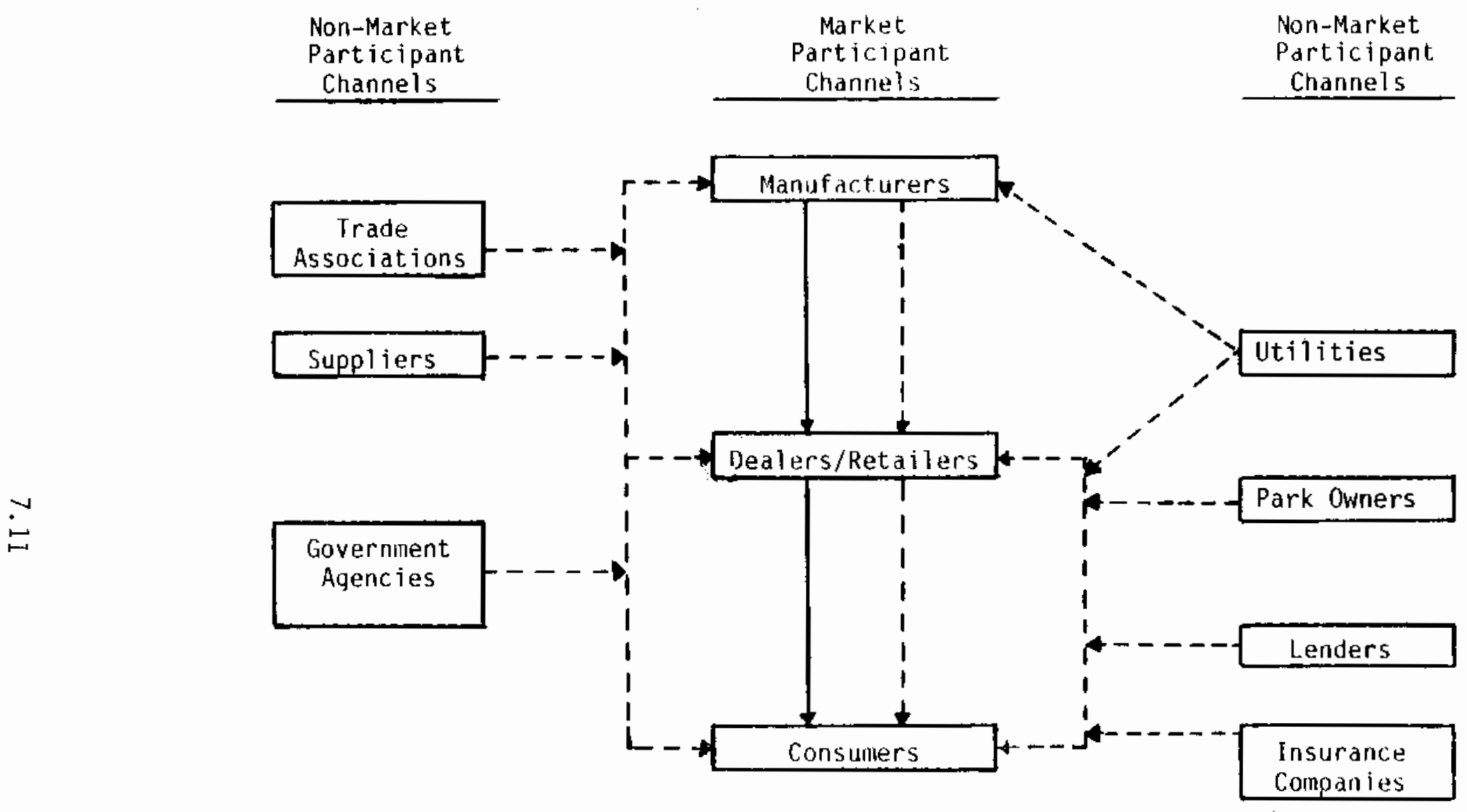

Product Flow

Influence/Inforiation Flow $-\rightarrow-\rightarrow$

FIGIJRE 7.2. Consumer Decision Participant Channels 
Market Participants

- Manufacturers

- This group of market participants in the consumer decision construct and assemble the home in factories. The homes are either custom ordered or built for dealer floor stock. There are approximately 23 manufacturers who operate 36 plants which deliver homes to the Northwest. These are listed in Appendix B. Fven with their relative remoteness from the consumer, the manufacturer would seem likely to play an important part in marketing strategies to influence the purchase of energy efficient homes. Marketing schemes directed at consumers from manufacturers would typically include information, advertising and promotional materials. Incentive structures or other benefits directed at manufacturers could also induce them to produce more energy-efficient units to be made available for dealer floor stock, rather than production of these upgraded models only on a "customer order" basis. Ready availability may be one way to increase market penetration of energy-efficient manufactured homes. Recall that up to $2 / 3 \%$ of manufactured homes are purchased off a dealers lot (Table 6.5).

- Dealers/Retailers - Dealers have the closest and most direct contact with (potential) consumers and, thus, are logically an important influence channel and market participant in the consumer's decision process. Dealers may sell one or several manufacturers' brands from their retail lot. There are, however, a few manufacturers who 
own their distribution network (e.g., Moduline Lamplighter sales outlets) and do not carry competing brands. Normaliy, dealers selit and deliver their homes only in a given geographic territory. It is usually their responsibility to prepare the land, do the foundation and utility work, and supervise completion work on the homes after delivery. Manufactured home dealers sell their units either from display lots, mobile home parks or both. There is a growing trend among dealers to sell from model homes in manufactured housing subdivisions. (4) The dealer should logically play a significant role in any marketing plan designed to increase sales of energy-efficient models and options. In the case where the manufacture owns the distribution network, the marketing focus should be the manufacturer: however, the incentives, selling tools etc. directed at dealers would be the same as for independent dealers.

- Consumers

- This is the last market participant in the distribution channel. They, of course, are the individuals or entities who actualiy purchase the home. A distinction needs to be made between purchasers (consumers) and occupants. While it is generally true that these groups are the same, this does not hold in all cases, for example renters. The distinction is important in terms of programmatic goals and marketing focus. For example, efforts directed at buying efficient new homes would be aimed at consumers, while some retrofit activities (shower flow restrictors) may be directed toward occupants of the home in general. 
- Utilities

- Park Owners and Real Estate Subdivision Manager/ Investors
- Utilities who serve various types of consumer groups can be a potential influence channel on consumers, retailers and builders of manufactured housing. Through incentives and other programs, these nonmarket participants can play an integral role in initiating and implementing a variety marketing programs designed to increase awareness of and propensity to purchase energy-efficient homes, For exampie, Duke Power Company (see Appendix A.1) uses an incentive rate structure to promote the purchase of energy-efficient homes and the retrofit of older homes. Depending on resources, goals and target audiences, a variety of potential marketing programs could be developed and inplemented by utilities.

- Because some of the potential marketing plan options involve the way in which the home is sited in a park or subdivision, these nonmarket participants could become important to the success of a marketing plan. The owners/ managers have influence for example in siting and setting up the home. Park owners or subdivision managers also have influence on consumers in terms of site selection and specific siting requirements.

- Government Agencies - This group of nonmarket participants has a great deal of potential influence on all market participants. A direct method would be through rules, regulations or standards. A second 
method may be through government programs or incentives, such as tax considerations, at each level of the channel.

- Lenders

- Lenders are beginning to offer special financing to buyers of energy-efficient home buyers. Because of the consumer's improved cash flow position due to lower monthly energy costs, some lenders have relaxed their norma? debt-to-income ratio as much as $2 \%$ (see Section 5.1). This practice can potentially qualify more consumers for financing and increase demand for energy-efficient manufactured homes. Financial institutions impact both retailers (home purchase and inventory financing) and consumers. Their role could become more important in terms of influencing consumer choice because of the financing terms they can make available for particular types of home purchases.

- Insurance Companies - While insurance companies do have an impact on the consumer decision process, it is not clear that this influence is positive in terms of buying energy efficiency options. Consumers treat the availability of insurance as important because of their concern for the general safety of a their home. $(7,8)$ However, as the general value of the home increases due to better materials or improved safety for example, insurance rates increase. Likewise, energy efficiency adds to the value of the home and, thus, increases insurance rates. Therefore, homes with upgraded energy-efficiency features will have higher market value, and as 
a result, higher insurance rates which may, in fact, discourage purchase of such options. The overall effect will depend upon the incremental rate increase and consumer's price sensitivity. Marketing program options may include potential incentives to insurance companies, depending on the insurance companies' overall effect and the marketing efforts cost effectiveness.

- Trade Associations - Each of the four states in the Northwest has a Manufactured Home Association whose members include both dealers and manufacturers. Appendix $C$ contains addresses, telephone numbers and contacts for each state association. The Associations' primary functions include 1) lobbying, 2) regulatory impact assessment and 3) information and education. Each of the associations expressed interest and willingness to participate in a marketing plan directed toward their membership. Membership levels are quite high (Table 7.1), thus, the trade associations may become an important element of a marketing plan given their ease of access to both manufacturers and dealers.

- Suppliers

- The manufactured housing industry utilizes more than $\$ 3.0$ billion a year in materials, supplies and services. (10) suppliers include product suppliers (appliances, lumber, insulation, etc.), land developers, financial institutions, after-market service distributors, regional suppliers and insurance companies. This group 
TABLE 7.1. Northwest Manufactured Home Association Membership

\begin{tabular}{|c|c|c|c|c|}
\hline State & $\begin{array}{c}\text { Number of Manu- } \\
\text { facturing Plants } \\
\text { in State }\end{array}$ & $\begin{array}{l}\text { Percent of } \\
\text { Manufacturers } \\
\text { within } \\
\text { the State } \\
\text { who are } \\
\text { As sociation } \\
\text { Members }\end{array}$ & $\begin{array}{l}\text { Approximate } \\
\text { Number of } \\
\text { Dealers } \\
\text { in state } \\
\end{array}$ & $\begin{array}{l}\text { Percent } \\
\text { Association } \\
\text { Menbers } \\
\end{array}$ \\
\hline Washington & 17 & $76.5 \%$ & $100^{(a)}$ & $52.7 \%$ \\
\hline Oregon & 11 & 100 & 100 & 35.0 \\
\hline Idaho & 7 & 100 & 56 & 82.1 \\
\hline Montana & 1 & 100 & 42 & 95.2 \\
\hline
\end{tabular}

(a) The Director of the Washington Association feels that only 100 of the actual 160 Association members are legitimate, viable MH dealers. Therefore, 100 was used in the table for comparison purposes. If 160 is used, the percent As sociation membership drops to $36.3 \%$.

of nommarket influence participants has a vested interest in increasing the sales of manufactured homes using their products.

Accordingly, suppliers of energy-related inputs such as insulation, thermal windows, and sheathing have an interest in fostering interest and sales of energy-efficient manufactured homes. The OwensCorning Fiberglas EQ home progran (Appendix A.3) is an example of a supplier seeking to influence the purchase decision. It is reasonable to assume that suppliers who would realize benefits of increased sales of energy-efficient homes will become more active at influencing the decision, and may be an attractive target for a marketing program designed to increase sales of such homes.

Because of the large number of potential participants in the consumer decision process, and the variety of roles each could play, there are a number 
of alternative program devices available. It is important, however, to select influence channels and focus on participants who will have the greatest influence on the decision. Through proper targeting, the marketing plan can better achieve its goals in the most costefficient manner.

\section{3 "LESSONS LEARNED" FROM OTHERS" EXPERIENCE WITH MARKETING PROGRAMS FOR ENERGY-EFFICIENT MANUFACTURED HOMES}

This section contains brief descriptions and "lessons learned" from existing programs designed to improve energy efficiency in manufactured homes. Appendix A contains the details of the programs. The programs have been designed and implemented by utilities, state energy offices, home manufacturers and suppliers. Their experience in developing and implementing these programs is a valuable input to the development of an analogous program for the Northwest. In this section, the experiences and "lessons learned" from these existing programs, both positive and negative, are discussed.

\subsubsection{Duke Power Company "Residential Conservation" (RC) Rate Program}

This program demonstrates that reduced energy costs are an effective means of influencing behavior. The preferential RC rate structure (detailed in Appendix A.1) is available to all types of residential structures, (site built, manufactured, multifamily, etc.) and for both new and retrofitted older homes in Duke's North and South Carolina service's area. The RC rate is a 1\% to $6.5 \%$ reduction in North Carolina, and a $1 \%$ to $17.7 \%$ reduction on the normal rate in South Carolina. The requirements to quality for the lower RC rate are:

- R-30 cefiling insulation

- R-12 (total) wall insulation

- R-19 floor insulation

- Storm windows and doors or insulated (double pane) windows and doors.

Alternatives to these requirements are acceptable as long as the total Btu loss is no greater than with the use of the required energy-savings components. Most manufactured homes that qualify for the RC rate do so through the substitution of alternatives. 
The program's success has been greatest with new housing. The following data illustrate the success of the $\mathrm{RC}$ rate program since its inception in the winter of 1978-79:

- From 1979 to 1981, only 2\% of all housing in Duke's service area met the $\mathrm{RC}$ rate qualifications;

- by $1984,85-90 \%$ of all new connects in Duke's service area met the RC qualifications and are thus charged the lower RC rate, and

- by $1984,27 \%$ of all homes in Duke's service area met the RC qualifications. $(\vec{a})$

While there has been tremendous success for new construction, the percentage of the total housing stock meeting the RC qualifications is lower than desired, due to the relatively low level of retrofit activity to date. To improve this situation, it seems that incentives, promotion or other marketing efforts and programs should be targeted at current home owners to a greater degree who do not qualify for the RC rate to encourage them to undertake retrofit measures. A cognitive or action change would be the appropriate goal of such efforts.

A potential drawback of using the rate structure as an incentive is that results may appear over longer periods of time because the primary focus is on new rather than existing homes. In Duxe's case, it took approximately 5 years for substantial results and, thus, conservation, to occur. The results are inainly due to upgrading new construction which, given market and economic conditions, may require longer periods of time to infiltrate the market. Concentrating efforts on existing housing stock through retrofitting may induce the desired behavior throughout the housing market and produce higher levels of results sooner.

(a) Comments are from a telephone conversation with Mr. Tom Burleson, Residential Construction Specialist, Ouke Power Company, Charlotte, N.C., February 1985. 


\subsubsection{Arkansas Power and Light's (AP\&L) Energy Saver Award Program}

The AP\&L program is basically a "certification program" similar to "Super cood Cents." The home is certified by the manufacture that it meets the AP\&L standards, and a seal is affixed to the electrical panel of the home attesting to this fact. The program was instituted approximately one year ago and has had 1 imited success. The major problems and the potential solutions AP\&L is considering are discussed below.

One problem has been the fact that meeting the required $40 \%$ energy use improvement over the HUD thermal performance standards adds approximately $\$ 2700$ to the price of the home. Dealers have found this price increase hard to sell, especially given the characteristics of the manufactured home market (lower income, rural, blue collar occupations, price sensitivity). AP\&L's approach to counter resistance has been to reposition (change) the program appeal as it pertains to cost. Because the AP\&L program requires the installation of a heat pump, air conditioning equipment is no longer needed and its cost can be subtracted from the incremental package cost as follows:

$\begin{array}{lc}\text { Energy Package } & \$ 1008 \\ \text { Heat Pump } & 1654 \\ \text { Less: Air Conditioning } & \langle \$ 1462\rangle \\ \text { Total Package Cost } & \$ 1200\end{array}$

This approach brings the effective package price down to $\$ 1200$ with a payback period of $31 / 2$ to 4 years. The package still costs the consumer $\$ 2662$, but $\$ 1462$ is avoided because the consumer does not have to order air conditioning. Dealers are encouraged to use this argument in their selling effort.

A second problem has been dealer resistance to inventoring the heat pump equipment, which is time consuming, space consuming and expensive. AP\&L is approaching this problem by investigating the possibility of allowing the dealer to arrange the heat pump installation at the home site through local vendors. 
AP\&L has had success with an institutional and co-op advertising program. Consumer awareness level of the "Energy Saver Award" program is high. The problems experienced by dealers are blamed for the minimal program success to date. AP\&L believes the dealers are the key participant in the consumer decision process and plans to focus its efforts on them to mitigate the current problems. (a)

The AP\&L program is cosponsored by the Arkansas Manufactured Housing Association whose name appears in the program advertisements and on the Energy Award Seal itself. The Association provides program information and support to dealers who are association members. One of the criteria to become a program participant (dealer or manufacturer) is to be a member of the Association. The Association provides AP\&L with the names and addresses of nembers for easier initial contact. It was also felt by AP\&L that the MH association's involvement would add legitimacy to the program and thus aid its acceptance by manufacturers, dealers and consumers.

\subsubsection{Owens-Corning Fiberglas Corp.'s Energy-Qualified (EQ) Home Program}

The Owens-Corning EQ home program has met with acceptance and success. The "recruitment" of program members occurs in one of two ways, depending on the product distribution network. Dealers can participate individually, or manufacturers can elect to participate and, in turn, recruit their independent or company-owned (or franchised) dealers. In either case, the primary focus is at the retail level through dealers.

Owens-Corning Fiberglass Corp. (OCF) strongly feels that the dealers are the key participants in the consumer decision process. Their closeness to the consumer and role as an information source put dealers in an important influence position. The EQ program provides dealers with selling tools and advertising support to aid their sales efforts. Because energy efficiency is an intangible item to purchase, the dealer's job is to make it as tangible as possible. The computer-based cost/savings charts for EQ homes developed by OCF for representative by geographic areas do just that--put energy efficiency in terms of cost savings. The institutional advertising which Owens-Corning does

(a) Telephone conversation with Roy C. Paulette, AP\&L, February 1985. 
creates consumer awareness (cognitive change). Consumers go into the sale with knowledge, and the dealers use of EQ sales tools help close the sale. Member dealers agree that the combination of advertising and cost/savings information is the key to the program's success. Another factor, which may become a more important selling point, is favorable financing for EQ homes (Section 5.1), but at present this is a minor concern to dealers. (a)

One potential drawback of a program such as this is the consumer's perception of information source credibility. Even though OCF is a nonmarket participant, it does have a vested interest in selling energy efficiency--the sale of Owens-Corning Fiberglas insulation. Dealers also have vested interests in selling upgrade packages--profits. Even though consumers realize these potential conflicts of interests exist, dealers claim that the consumer is well educated on the value of energy efficiency and respects the credibility of OCF. Thus, these concerns have not become a hindrance to sales.

\subsubsection{State of Maine "Energy-Efficient Manufactured Home Program"}

The "laine "Energy-Efficient Manufactured Home Program" results have been less satisfactory than expected. Inder the program 20 energy efficient IH's were built by two manufacturers participating in the program in the fall of 1984. The cost of developing and printing the program literature was paid for by the Maine llanufactured Housing Association. The Maine Office of Energy Resources awarded grants of $\$ 2828$ to qualified consumers to purchase these homes. As of March, 1985, only 10 of the homes had been sold. The sponsors attribute the relative lack of success to a number of factors. One important factor was the timing of the program's introduction. The manufactured home selling season in Maine ends (or drastically tapers off) by mid November. The program was introduced in December, 1984 with minimal promotional efforts directed to consumers.

Another factor contributing to lower then expected sales has been the dealer's level of information and education about energy efficiency. Once the program had begun, the dealers, and manufacturers to a lesser degree, were

(a) Documentation for the EO program can be found in Appendix A.3. 
found to need additional training and education about energy efficiency and energy-saving equipment. This finding necessitated the development of educational programs for both dealers and manufacturers (the two involved as partners with the office of Energy Resources). The educational aspect of the progran for all parties is considered one of the progran's successes.

The program was set up as a contest of sorts where 20 Maine residents, with incomes of $\$ 28,000$ per year or less could win a $\$ 2828$ subsidy to be applied to the purchase one of the 20 homes built. The subsidy essentially covered the cost of the energy-efficiency upgrade. Several of the Program rules are worth noting:

- The siting requirement that $80 \%$ of the windows or glazed surfaces of the home must face south is designed to take advantage of an $11 \%$ to 16\% solar gain. Siting seems to be a low involvement, action change for consumers with potentially large returns in terms of energy savings.

- A year of energy records must be made available to the office of Energy Resources. The "winners" of the subsidies were selected partially based on their geographic location. An even distribution of homes across the state is desired for meaningful, state-wide energy end-use tracking.

- The subsidy recipients need to obtain financing comitments and certify their income levels.

- The subsidy recipients must open their home to the public, during specified times, as part of the marketing effort. This requirement, depending on when and how long the specified times were, may have a negative effect on sales of the homes and interest in the program. Burlington Homes of New England, Inc. (Appendix A.5.1) was one of the two manufacturers building the homes for this program. It made no special marketing effort for these homes in terns of promotion or incentives. Rather, the idea of conservation was presented to dealers in terms of additional profit 
margin, and the dealers resold the idea to home buyers. In retrospect, Burlington's feeling is that incentives of some kind to the dealers would have improved the selling effort of the homes and, thus, the success of the program. 7.3.5 Wick Building Systems, Inc.

The Wick Building Systems project involved the construction of a highly insulated, passive solar manufactured home, the Mdel 650. There were some valuable lessons learned during the duration of the marketing program for this home that are potentially applicable to the Northwest. The lodel 650 was marketed for one year (1982-83), was subsequently withdrawn and is no longer being produced. There were a variety of problems associated with the product's failure in the market, each of which is discussed below.

The first, and largest problem was cost. The solar home features added approximately $\$ 6000$ to the retail price of this single wide home. This amounted to a 23 to $30 \%$ increase in the retail price to consumers. Given the high level of price sensitivity $(9)$ manufactured home consumer's exhibit, a $28 \%$ price increase significantly impacted market demand for these models. In addition to its effect on demand, the payback period for this package was approximately 9.5 years. According to wick's market research, the largest group of consumers of manufactured homes own the home for 3 to 3-1/2 years. The second largest group of owners keep the home for 7 years. Nither of these groups, which make up the majority of consumers, would realize net savings as payback would not be reached by the time the home was sold. The only yroup of consumers who typically own a manufactured home longer than 10 years are retirees. Wick determined that targeting only this group limited the market too much to make production and marketing efforts viable.

A second problem encountered centered around the homes' high level of technology. The home was sophisticated and unique, necessitating a great dea? of dealer training to sell the homes. Consumers were often overwhelmed with technical information. Although dealers were given seminars which prepared them for typical consumer questions, wick found that dealers had neither the desire nor the technical background to teach their sales people about the home and its characteristics. Likewise, the information handed to consumers was far too technical for a layman to understand. The information and educational 
programs were found to need simplification and reduction to the most salient factors, presented in terms understandable by both sales people and consumers.

A third problem centered around the computer model Wick had developed to estimate the actual energy costs of the home for a particular family at a particular site. Inputs to the model included family habits, characteristics and lifestyle patterns. The model also contained simplifying assumptions, such as cooking habits, number of laundry loads washed, etc. to be able to make energy cost calculations. Dealers found the model overly technical and requiring too many detailed inputs and too much time to make it a useful sales tool. Also, the assumptions of the model were not explained to consumers, and the wording on the energy cost printout did not cleariy state that the energy cost generated from the model was only an estimate and could vary from actual energy use. As a result, legal problems arose for Wick when consumers' actual energy cost differed from the costs estimated by the model. These problems have been subsequently resoived. The Owens-Corning Fiberglass EQ Progran energy consumption estimates attempts to minimize these potential misunderstandings by including a carefully-worded disclaimer which states 1) that the numbers are only estimates, 2) the assumptions used to generate the estimate, and 3) that actual energy costs may vary depending on actual use situations. Neither Owens-Corning Fiberglass, nor EQ Home Program members have experienced legal problems over these estinates.

\subsection{POTENTIAL MARKETING PROGRAM OPTIONS}

There are a variety of marketing program options potentially available to BPA to foster the purchase of energy-saving homes and options, or encourage energy-conserving behaviors. The options can be focused at market as well as nonmarket participants in the consumer decision process as discussed in Section 7.3. The options discussed below are not mutually exclusive; rather, a desirable marketing program may be a combination of options directed at mu?tiple actors and actions in the consumer decision process. An example of a marketing program that combines a variety of options is suggested by OwensCorning Fiberglas, (11) discussed in Subsection 7.4.8. Before discussing option combinations however, each of the option categories is discussed individually. 


\subsubsection{Advertising}

Advertising can provide a means to cost-effectively reach a large group of persons with a desired message. Advertising also lends itself to market segmentation through time-of-day, type of television show or radio station selection for electronic media, and/or through particular publications or ad placement for the print media. Different types of advertising can be enployed:

- Institutional Advertising - This type of advertising is not product oriented but rather attempts to convey an idea, inage or attitude, such as conservation, to the target market. This type of advertising is sometimes considered part of a public relations effort, but more importantly, it serves the attention-awareness roles of a marketing program. The AP\&L and Owens Corning Fiberglass prograns both utilize institutional advertising.

- Co-op Advertising

- This is joint advertising between one or more organizations. The costs and the benefits of this type of advertising are shared between the organizations

involved. For example, BPA and specific manufacturers and/or dealers could jointly share advertising costs. The other benefit of such an arrangement is each organizations name being associated with the program and the advertisement. The AP\&L Progran utilizes co-op advertising in the programs Phase II advertising approach (Appendix A.2). A related forin of co-op advertising is simply making promotional allowances available to manufacturers and/or 
dealers. Here, BPA could make funds available, most likely on a cost-shared basis, to manufacturers or dealers to advertise energy-efficient homes (e.g., Super Good Cents homes).

- Educational-Informational Advertising

- This type of advertising seeks to educate or convey information as its goal. Advertisements which explain the rational behind conservation could aid in acceptance. It would seem given the discussion in section 6.0 on consumer attitudes, that a possible misunderstanding of the role of conservation during energy surplus situations exists. Repositioning conservation as a "money saving" or "home improvement" activity and away from one of saving energy fiay also aid acceptance and participation. This type of advertising is also an appropriate vehicle to announce or inform consumers as to the availability of existing programs as well as to introduce new programs. As discussed in Section 5.2, credible information can help reduce sales barriers.

\subsubsection{Electricity Rate Incentives}

Using electricity rate structures as incentives to participate in conservation programs and/or invest in energy-saving equipment would seem to be an effective marketing tool. Potential incentive rate schemes include;

- reduced hookup fees for homes built to specified energy-efficiency standards and/or siting requirements (southern orientations to take advantage of solar gain) 
- reduced electricity rate schedules for residential structures that meet specified thermal requirements

- reduced electricity rates for park owners for common areas of the park (such as laundry facilities, recreation facilities and park lighting), who require southern oriented siting of homes in their park or other thermal characteristics.

An example of a program utilizing incentive rate structures is the Duke Power RC program (Appendix A.1).

\subsubsection{Certification Programs}

This marketing program option has been widely used with a good deal of success. These types of programs call for the certification of homes which meet the certifying agency's thermal standards. The home is certified with a "seal of approval" which consumers are encouraged to look for through advertising. The home buyer also can be presented with a certificate that states exactly what thermal features went into the home and, in some cases, the estimated cost of energy to operate the home. These certificates can become a valuable asset for subsequent resale of the home. This possibility also helps mitigate consumer concerns that may arise when tenure in the home is likely to be shorter than the payback period for energy efficiency options. With such a certification, the consumer can potentialiy realize benefits of these options when the home is sold even before the payback period. This type of program is generally used in conjunction with some type of advertising about the prograri, the "seal of approval" and certificate of thermal integrity. Examples of such programs include:

1. Arkansas Power and Light Company (Appendix A.2)

2. Owens-Corning Fiberglas, Inc., Energy-Qualified Home Program (Appendix A.3)

3. The BPA Super Good Cents Program.

7.4.4 Informational and Educational Programs

This option includes a variety of instructional material development to educate and/or inform consumers, dealers, manufacturers or any other decision 
participant in the consumer decision process (e.g., lenders, park owners etc.) about the merits of energy conservation. Specific areas that could be addressed include:

- cost/savings/payback information on energy options

- indoor air quality as it relates to "tightening" homes

- home value increases

- what to look for when shopping for an energy-efficient home

- $10 w /$ no cost actions to reduce energy usage

- why conservation is necessary given adequate energy supply

- how to site the home to take advantage of solar gain

- what energy use options are available and how they can be combined most effectively.

A variety of media could be used to implement this option. Advertising, brochures, booklets, sales promotion tools and seminars may all be appropriate. Existing examples include:

1. Owens-Corning EQ home program (Appendix A.3)

?. Wick Building Systems dealer support (Section 7.4.5)

3. Consumer-oriented booklets on manufactured home energy efficiency (Appendix A.5)

4. DOE "Affordable Manufactured Housing Through Energy Conservation" slide-rule sales tool

5. Seminars and educational programs (Appendix A.4).

\subsubsection{Demonstration Programs}

This program option would be designed specifically to demonstrate the value and features of energy-efficient manufactured homes. Again, the focus could be on dealers, manufacturers or consumers, depending upon the programs' objective. For example, a program to demonstrate that energy-efficient homes can be built to specific thermal standards would be directed toward manufacturers. An analogous progran would be the Residential Standards Demonstration 
Program (RSDP) undertaken by BPA. An on-line computer model is a second example of a program dealers could use to demonstrate the effects of various energy-related options on energy use and cost. Another example of a demonstration program is the "Energy Room" used by wausau Homes (Appendix A.3.1). This room is designed to position energy efficiency as a "value-added" option which is physical and tangible.

\subsubsection{Einancial Programs}

This set of options includes financial incentives other than rate incentives to encourage the purchase of energy-efficient options. There are a variety of potential financial incentives available ranging from rebates on the purchase of specific equipment or packages, to direct subsidies to builders and/or purchasers of energy-efficient homes. Examples of non-rate financial incentive programs include;

1. Owens-Corning Fiberglas, EQ home rebate program (Appendix A.3)

2. Wausau Homes promotional discounts (Appendix A.3.1)

3. Maine Office of Energy Resources program (Appendix A.4)

4. RSDP program.

\subsubsection{Siting Programs}

This option could include programs designed to influence the siting of the home to take advantage of passive solar gain. Examples where siting was a component of the qualification or certification program are

1. Wick Home Systerns (Appendix A.6)

2. Maine Office of Energy Resources program (Appendix A.4).

\subsubsection{An Integrated Marketing Program Designed by Owens-Corning}

Consumer perceptions about the energy efficiency of manufactured homes is believed to be a significant barrier to their sales. Owens-Corning Fiberglass suggests the following as desirable features of marketing programs designed to increase the purchase of more energy-efficient manufactured homes. (11)

- Promote energy efficiency - develop return-on-investment figures and pay-back periods for higher levels of insulation and energy-saving components 
- Sell higher resale value of energy-efficient units

- Educate sales force on R-values

- Hand out literature detailing HJD heat loss requirements and regulations

- Collect a year's fuel bilis for an energy-efficient unit and use these as a sales tool

- Use cutaway displays to show insulation levels

- Demonstrate how units are sealed against drafts-calking, thermal sealing, energy-saving doors and windows

- Show how fuel savings can help pay mortgage

- Take advantage of sales tools provided by manufacturers and suppliers.

This program integrates several of the options discussed into a unified marketing program to promote the sale of energy efficient upgrades and homes.

\subsection{DESIRABLE FEATURES OF A MARKETING PROGRAM}

This section discusses desirable features of a marketing plan to enhance the sale of ECOs on new MHs. The discussion covers design issues $(7.5 .1)$, cost effectiveness (7.5.2), implementation (7.5.3), and control (7.5.4).

\subsubsection{Design Issues}

The first step in developing appropriate marketing prograins is to clearly establish the goal(s) of the program. If the goals are to be achieved, they should be:

1. Achievable (realistic)

2. Measurable (quantifiable)

3. Motivational

4. Flexible

5. Clearly stated, and

6. Stated in terms of a time horizon. 
Goals such as "a $10 \%$ increase in market share within 12 months barring any major changes in market conditions" is an acceptably stated goal (as long as it is realistic). Once it is determined exactly what is to be accomplished and by when, a program can be designed to achieve the desired goals.

Al 1 marketing programs must approach the consumer and his decision process from the same premise, that there are stages which consumers go through when making a purchase decision. There are two models which help explain these stages of consumer response. AIDA is an acronym for the various stages consumers go through in making their purchase decisions. The stages are: (12)

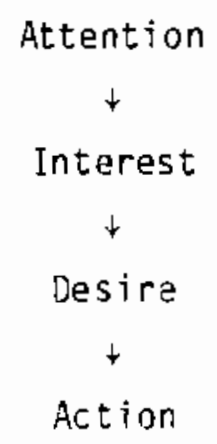

The second mode1, the Hierarchy of Effects hodel, is essentially the same as the AIDA model, but is more detailed in terms of description. The Hierarchy of Effects model describes the steps consumers go through as: (13)

\author{
Awareness \\ $\downarrow$ \\ Knowledge \\ $\downarrow$ \\ Liking \\ $\downarrow$ \\ Preference \\ $\downarrow$ \\ Conviction \\ $\downarrow$ \\ Purchase
}


Depending on the consumer's current levels of each or any of the model's variables, a marketing progran can be designed to affect all or parts of the decision process as necessary. Therefore, in the design stages of a marketing program, an evaluation should be made to determine the program's focus within the consumer purchase process.

Once the goal(s) and focus of the program are defined, the actual elements of the program can be determined. Marketing programs are usually a blend or combination of 4 elements:

- Sales promotion

- Personal selling efforts

- Publicity/public relations, and

- Advertising.

Each element has its own particular characteristics which may make it more appropriate on a situational basis. At the design stage, each element should be evaluated for its applicability and blended with the others to create the most effective program as possible.

After preliminary design efforts have been completed, a progran budget should be established so that the cost-effectiveness of each element can be evaluated within the scope of the budget. The most desirable method of determining the budget is the "objective and task" approach. First, the goals of the program must be stated. (12) Secondly, the tasks which need to be implemented to achieve these goals are determined. The program budget simply becomes the sum of the cost of each task. This approach to budgeting provides a direct link between goal achievement and expenditure, and provides direction for program spending.

\subsubsection{Cost-Effectiveness}

The extent of sales promotion, personal sales, publicity/public relations and advertising that is desirable is based on their respective cost effectiveness. Each element varies in cost and the number of consumer contacts made. Figure 7.3 indicates that indirect promotion is efficient but not 


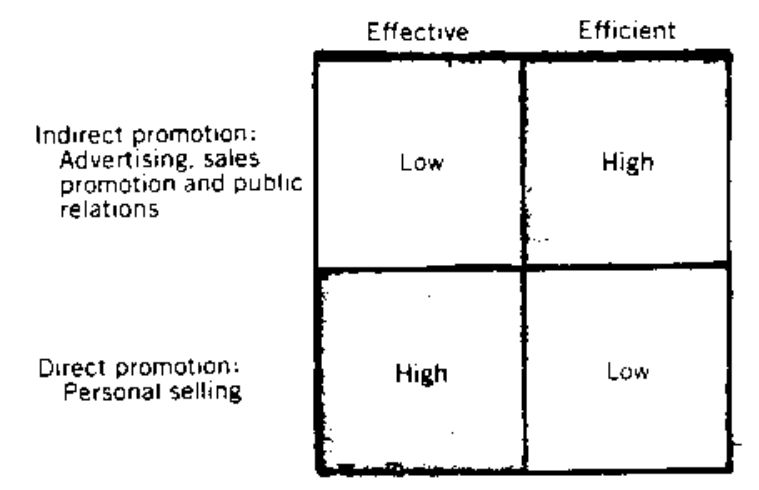

FIGURE 7.3. The Relative Merits of Alternative Promotional Mix Activities (14)

effective. Direct promotion, however, is found to be effective but not efficient. The key to understanding this matrix lies in the terms "effectiveness" and "efficiency".

Effectiveness means that the activity has a high per customer contact sales rate. That is, if the program contacted (reached) $10 n$ people, and 75 of them purchased the product, the program would he considered effective. Direct promotion programs are generally effective hecause the sales efforts are personalized and directed at one or a few consumers at a time. Thus, the sales rates are often high as a percent of consumers contacted. Indirect promotion however, is generaliy less effective because many potential consumers are contacted, hut the sales rate is usually lower.

Efficiency refers to the cost per customer contact. Indirect promotion is considered efficient because the cost of each contact is quite low. Personal selling however, is expensive per customer contact. Thus, direct approaches to specific consumers (i.e.; personal sales) are considered inefficient.

Note that the reason indirect promotion is efficient (low per customer contact cost) is highly related to the reason it is ineffective (low per customer contact sales rate). This relationship is called the "promotional paradox" and is inherent in all marketing programs. (14) A program can rarely be both effective and efficient; rather a balance of sales promotion, personal sales, publicity/public relations and advertising must be determined for each application and budget. 


\subsubsection{Implementation}

Once the program has been developed to achieve the desired goals, the various strategies and tactics need to be put into place and implemented. Proper assignment of personnel and resources as well as developing plans as to how each goal will be met are essential to the program success. Shorter term plans must be designed, scheduled, sequenced and implemented to achieve the longer terim program goals.

\subsubsection{Control}

The last element of a marketing program is control. The program must be monitored on a regular basis to ensure that progress is being made toward the estabitished program goals. Control is the reason goals should be stated as outlined in Section 7.5.1. If goals are not measurable and clearly stated, progress toward them in the desired time perjod can not be determined. If progress is not being made toward the desired goals, interim adjustments to the program strategies and implementation or goal redefinition can be considered.

\subsubsection{Preliminary llarketing Program Suggestions}

With the previous discussion as background, potential marketing program elements will be suggested. There is no attempt made to design an actual program at this point. Rather, suggestions based on al1 previous discussion are made for consideration to be included in a marketing program designed to increase the purchase of energy-efficient manufactured homes.

An important goal of such a program is to reduce or eliminate the barriers to consumer purchases of energy efficient homes (Section 5.0). These barriers are financial and informational in nature. It would appear that to reduce the financial barrier, lenders should be included as a program target. Given manufactured home consumers' income levels and price elasticity (Section 2.0), there appears to be a potential to qualify more buyers for debt on energy efficient homes, and thus, increase their sales and market penetration.

The information barrier is somewhat more difficult to overcome because of the variety of sources of information available to consumers and the consumers lower education level. Credibility is the key to information acceptance. 
Table 6.32 indicates that the consumers local utility is perceived as most credible. Therefore, utilities appear to be a logical target of the program as wel1.

The types of information which BPA would need to present to increased consumer purchases of ECOs in new MHs will vary depending on which stage(s) of the AIDA or Hierarchy of Effects model the prospective consumers are found to be in. Table 6.21 indicates that about half of manufactured home consumers believe that the way to reduce electricity bills is to change their lifestyle. Information to convince these consumers that they can reduce their electricity bills through the purchase of energy-efficient home options, without sacrificing comfort or lifestyle would be appropriate. This group of consumers would be at the Awareness/Knowledge stage of either model and marketing efforts should be appropriately directed. Other consumers, such as those in newer manufactured homes (Tables $6.24,6.24$ and 6.26 ) appear to be already aware of the ECOs available to reduce their electricity bills and are thus, further along in the decision models. Again, marketing efforts targeted at these consumers needs to be appropriately targeted.

Dealers also seem to be an important decision participant and shouid be included in the marketing program. The dealers closeness to the consumer and ability to influence the purchase decision (Section 6.3) indicate that appropriate sales training, tools and incentives may be effective in influencing the purchase of ECOs. Dealers are also responsible for ordering their own floor stock, from which approximately two-thirds of manufactured homes are purchased. The dealers potential influence (in both ways) on the market penetration of energy efficient homes appears substantial and warrents consideration for program inclusion.

Other general considerations include the average tenure of manufactured home residents. Table 6.17 indicates that most plan to occupy the home at least 5 years. Marketing efforts must not ignore the consumer with a shorter tenure horizon. It is important that consumers with a shorter tenure also see some value to purchase ECOs, even if they will not stay in the home past the payback period. This can potentially be done through programs like "Super Good Cents" which certify the thermal features of the home. The value of the ECOs 
added to the home can potentially be recovered through an increase resale value of the home, aided by the certificate of thermal integrity. This type of an appea? may have potential to increase efficient home purchases from more types of consumers, including those with short tenure horizons.

A second general consideration which is somewhat unique to the Northwest is that a larger percentage of manufactured homes sold in this area are mult $i-$ section (Section 2.0). These larger homes have a greater potential for energy savings, suggesting a potentially large market for ECOs in the Northwest.

\subsubsection{Conclusions}

This discussion suggests a number of considerations to take into account when designing a marketing program for increasing the purchase of ECOs in manufactured housing. The most likely targets of such a program appear to be: 1) consumers, 2) lenders, 3) utilities and 4) dealers. Consumers appear to be at different stages of the decision process models and thus program efforts must be directed to particular consumers in specific stages to be effective. A combination of advertising, sales promotion, incentives and other features appears to be the best approach given the number and type of prograrn targets. A combination of elements in the nost cost-effective manner is most desired.

The market for ECOs appears to be large. Consumer awareness of ECOs is high and future intent toward their purchase is favorable. Both conditions, together with electricity supply and price considerations would indicate success for a marketing plan for ECOs in manufactured housing. 
REFERENCES AND NOTES FOR SECTION 7.0

1. Philip Korler; Marketing for Nonprofit Organizations, 2nd edition, Prentice-Ha11, 1982 .

2. Herbert H. Hyman and Paul B. Sheatsley, "Some Reasons Why Informational Campaigns Fail," Public Opinion Quarterly, Vol. 11 pp, 412-23, 1947.

3. Philjp Korler, Marketing Management, Analysis, Planning and Control, 5th Edition, Prentice-HT, 1984.

4. The Market, the Magazine, Automation in Housing and Systerns Building News, September, 1983, (insert).

5. Automation in Housing and Manufactured Home Dealer, "Lenders Offering Special Financing for "Energy Qualified Womes," p. 12, February 1985.

6. Owens-Corning Fiberglas Corporation, Do Mortgage Lenders Favor EnergyEfficient Homes? July, 1984.

7. Mobile/Manufactured Home Merchandiser, "How Does the Public View Mobile/ Manufactured Homes?," July 1984.

8. Owens-Corning Fiberglas Corporation, A New Perspective, The American Dream, 1985.

9. Howard Gates, Price Elasticity of Demand for Hanufactured Homes, prepared for MHI, March 7, 1984 .

10. Duane B Smithem, "Todays Home; Manufactured Housing, King, Pierce \& Thurston Counties," p.7, March 1985.

11. Owens-Corning Fiberglas Corporation, Behind Every Barrier There's a Buyer, A report to the Mbile Home Industry, A suminary of Barrier-Breaking Strategies from 1979 Deder Business Conference, January, 1980.

12. Thomas C. Kinnean and Kenneth L. Bernhardt, Principles of Marketing, lst edition, Scott, Foresman and Company, 1983.

13. Robert J. Lavidg and Gary A. Steiner, "A Model for Predictive Measurements of Advertising Effectiveness," Journal of Marketing, October 1961, p.61.

14. Rom J. Markin, Marketing Strategy and Management, 2nd edition, John Wi\}ey and Sons, Inc., 1982. 


\subsection{ABBREVIATIONS AND GLDSSARY}

$A C$

Act

AIDA

A1

AMHA

AP\&L

BPA

$8 \mathrm{tu}$

CFR

COP

Council

DOE

ECO

EQ

HIJD

IAQ

kivh

LPG

Manufactured Home

MCF

MCS

$\mathrm{MH}$

MHCSS

MH I

$m m B$ t $u$

NA

Northwest

OCF

OSFDH

Plan air conditioner

Pacific Northwest Electric Power Planning and Conservation Act

Attention - Interest - Desire - Action

A1 umi num

Arkansas Manufactured Housing As sociation

Arkansas Power and Light Company

Bonneville Power Administration

British thermal unit

Code of Federal Regulations

Coefficient of performance

Northwest Power Planning Counci?

U.S. Department of Energy

Energy conservation option

Energy Qualified Home Program

U.S. Department of Housing and Urban Development

Indoor Air Quality

kilowatt hour

Liquid propane gas

As used in this report, a manufactured home is a home built to the HUD MHCSS

million cubic feet

Model Conservation Standards

manufactured home

HUD Manufactured Home Construction and Safety Standards

Manufactured Housing Institute

millions of Btu

not applicable

The Pacific Northwest Region as defined in the Act Owens-Corning Fiberglas Corp.

other single-family detached homes (i.e., single-family detached homes other than manufactured homes)

Northwest Conservation and Electric Power Plan 
PNL

PNWRES

$\mathrm{RC}$

RSDP

SEER

USCA
Pacific Northwest Laboratory

Pacific Northwest Residential Energy Survey

Residential Conservation (referring to Duke Power Company's Residential Conservation rate progran)

Residential Standards Demonstration Program

seasonal energy efficiency ratio

United States Code Annotated 


\section{APPENOIX A}

EXISTING PROGRAMS TO ENCOURAGE ENERGY CONSERVATION IN MANUFACTURED HOMES 
APPENDIX A

\section{EXISTING PROGRAMS TO ENCOURAGE ENERGY CONSERVATION IN MANUFACTURED HOMES}

This appendix contains detailed information on programs from throughout the country designed to increase awareness of and/or propensity to purchase energy conservation measures or equipment in manufactured homes. Each program is presented in the following format:

- Program Title

- Program Sponsor

- Program Contact within sponsoring entity

- Program Description

- Current status of the program

- Documentation.

The following programs are described:

A.l Duke Power Company Residential Conservation Rate Structure

A.2 Arkansas Power and Light Marketing Program for Manufactured Housing

A.3 Owens-Corning Fiberglas Corp's Energy Qualified Homes Program

A.3.1 Wausau Homes (Wausau, Wisconsin)

A.3.2 Acme Homes (Olympia, Washington)

A.3.3 McCullough Homes Center (Moses Lake, Washington)

A.4 State of Maine Office of Energy Resources Energy-Efficient Manufactured Home Program

A.5 Consumer Oriented Booklets on Manufactured Home Energy Efficiency

A.5.1 The Energy-Efficient Manufactured Home in Texas

A.5.2 The South Dakota Mobile Home Energy Savings Guide

A.5.3 An Energy Diet for Mobile Homes: An Owners Guide to Saving Money

A.5.4 Energy Conservation Ideas for llobile Homes 
A.6 Wick Building Systems, the Solar Model 650

A.7 Ford Glass Division, SAVE Program

A.2 


\section{A.1 Program Title Residential Conservation (RC) Rate Structure \\ Program Sponsor Duke Power and Light Company \\ Program Contact Mr. Tommy Burleson \\ Duke Power Company \\ 430 South Church Street \\ Charlotte, North Carolina 28202 \\ (704) 373-5901}

Program Description

The Duke Power preferential RC electricity rate is available to all individually-metered residential customers in "residences, condominiums, manufactured homes, or apartments irrespective of the source of energy for environmental space conditioning or water heating." To qualify for the rate, the structure must meet the following themal requirements:

- Ceiling:

Insulated to R-30 (insulation on ly)

- Outside Walls: Insulated to R-12 (total wall)

- Floors:

Insulated to R-19 (insulation only)

- Windows:

Insulated glass or storm windows

- Outside Doors:

Insulated or equipped with storm doors and weatherstripping. Doors exposed to unconditioned areas of the home such as a garage or basement must be weatherstripped.

- Air Ducts:

Ducts located outside of conditioned space must have all joints mechanically fastened and sealed and insulated with 2 inches of R-6.5 duct wrap insulation or its equivalent.

- Attic Ventilation: Minimum of one square foot of free area for each 150 square feet of attic area. Mechanical ventiTation or ceiling vapor barrier, in lieu of free area, may be used where necessary, subject to special approval. 
- Chimney Flues and Fireplaces equipped with tight-fitting dampers.

There are "Alternate Equivalent Performance Standards" available. Most manufactured homes have qualified for the RC rate progran under these alternatives as described below.

"Variations may be made in the insulation standards as long as total heat loss does not exceed that calculated using the specific standards above. Duct or pipe losses shall be included in the computation of total heat loss. Duke Power's procedure for calculating heat loss or the current edition of the ASHRAE Guide shall be the source for heat loss calculations." (1)

Dnce the home qualifies, the RC rate structure becomes effective. The rate structure provides a $1 \%$ to $6.5 \%$ discount in North Carolina and $1 \%$ to $17.7 \%$ discount in South Carolina over the non-qualifying home rates based upon actual kilowatt usage, up to $5000 \mathrm{kWh}$ used per month. The scale is progressive; the more electricity used the greater the percentage discount up to $5000 \mathrm{kWh}$ used per month. After $5000 \mathrm{kWh}$, there is no discount. The North Carolina rate was originaliy comparabie to that of South Carolina but the North Carolina Utilities Commission reciently reduced the percentage and discount.

\section{Current Program Status}

The progran is currently in place and has become quite effective in increasing the number of energy-efficient residential structures (including MHS) in the Duke Power service area (principally North and South Carolina). The percentage of residential structures meeting the $\mathrm{RC}$ requirements has increased from $2 \%$ initially to approximately $27 \%$ currently. Of all new residential connects for Duke Power, between $85 \%$ and $90 \%$ meet the RC requirements. Future efforts will be focused on retrofitting existing residential structures.

\section{DOCUMENTATION}

1. Duke Power Company, Get Your House Ready for Lower Energy Bills, A Guide to Qualifying for the RC Electric Rate, May 1981. 
2. Schedule RD (NC) Residential Service, Energy Construction, North Carolina Utilities Commission Docket No. E-7, Sub 373, June 13, 1984 and South Carolina Public Service Commission Docket No. 80-50-E, Order No. 83-92, South Carolina Public Service Commission Docket No. 17-394-E, Order No. 83-817, December 1, 1983. 

A.2 Program Title
A Marketing Program for Manufactured Housing
Program Sponsors
Arkansas Power and Light Company (AP\&L) and Arkansas Manufactured Housing Association
Program Contact

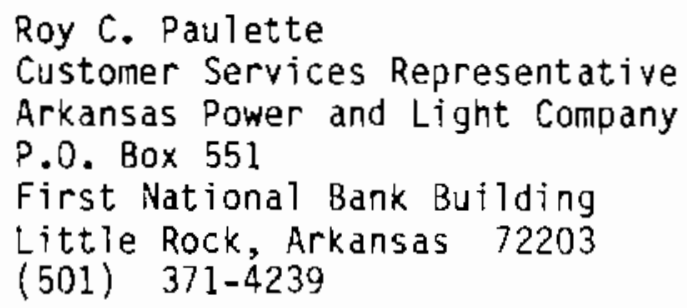

Program Description

The program consists of five elements.

1. The first element is the "Energy Saver Manufactured Home Award" which is a performance certification granted by AP\&L. The certificate and decal identify manufactured homes which meet the program's thermal performance criteria. The decal is placed on the home's electrical panel by the manufacturer. The manufacturer also provides AP\&L with a monthly list of all models and serial (or ID) numbers to which award emblems have been attached, as well as the unit's destination.

2. The performance standards required for program participation are based on a $40 \%$ improvement over the minimum themal performance standards in the MHCSS and the use of properly-sized, high-efficiency heat pump equipment. The maximum acceptable heat loss transmission coefficient under the program is $0.0942 \mathrm{Btu} / \mathrm{hr} / \mathrm{sq} \mathrm{ft} /{ }^{\circ} \mathrm{F}$ compared to the HUD maximum of 0.157 for Zone 1 .

3. The "Energy Saver" Manufacturers' Agreement outiines the specific requirements for participation in the program and establishes the criteria whereby homes qualify for the Energy Saver Award. The only requirement in terms of equipment is the heat pump. The marufacturers are free to meet the energy standards in the least cost manner to them. The agreement also provides that AP\&L and its representatives reserve the right to visit the manufacturing facility to 
observe the construction of homes designated under this program. The manufacturer must also be a member of the Arkansas Manufactured Hone Association (AMHA).

4. The "Energy Saver" Dealer Agreement for program participation identifies eligible dealers and provides criteria for program participation. Specific elements of the agreement include:

- Dealer shall provide AP\&L with a list of certified homes they have sold in the AP\&L service area

- The homes are to be accessible to AP\&L employees for observation during setup and installation of outside equipment

- Dealers must be a member of the AMHA.

5. Two-Phase Advertising and Promotion of the Energy-Saver Manufactured Home

Phase 1 - Manufacturer Incentive Advertising (Institutional Advertising)

The first phase of the advertising program was designed to announce the basic program and provide incentives for manufacturers to build and offer homes to dealers. These advertisements attempted to achieve the following goals:

- Identify manufacturers who are participating in the program.

- Explain the Energy Saver Package in terms of energy savings to potential home buyers

- Create a prominent identity for the certification seal and urge prospective buyers to search for the seal before purchasing

- Alert prospective buyers to watch for upcoming local dealer advertising.

Phase 2 - Dealer Incentive Advertising (Co-op Advertising)

The second and ongoing phase of the advertising program provides incentives for dealers to inventory Energy Saver Homes and increase sales efforts to AP\&L customers. The specifics include: 
- Offering a cooperative advertising allowance of $\$ 300.00$ to any dealer who inventories at least two Energy Saver homes at the start of the dealer's program participation

- Offering dealers an additional cooperative advertising allowance of $\$ 150.00$ for each Energy Saver home sold and sited in the AP\&L service area. The dealer must have at least one Energy Saver home on the sales lot at the time advertisements are placed. The allowance applies to radio and print advertisements only.

Example Performance Standards and Costs

With the exception of the heat pump, there are no specific equipment required to meet the program requirement of a $40 \%$ improvement in energy efficiency over the HUD standard. An example of a package prepared by AP\&L which a manufacturer could install to qualify the home under the Energy Saver Progratn is shown in Table A.1. Also included are illustrative thermal measures that can be used to meet the HUD MHCSS thermal requirements. Btu reductions and dollar costs are calculated and included. 


\section{TABLE A.1. HUD and AP\&L Construction Comparisons}

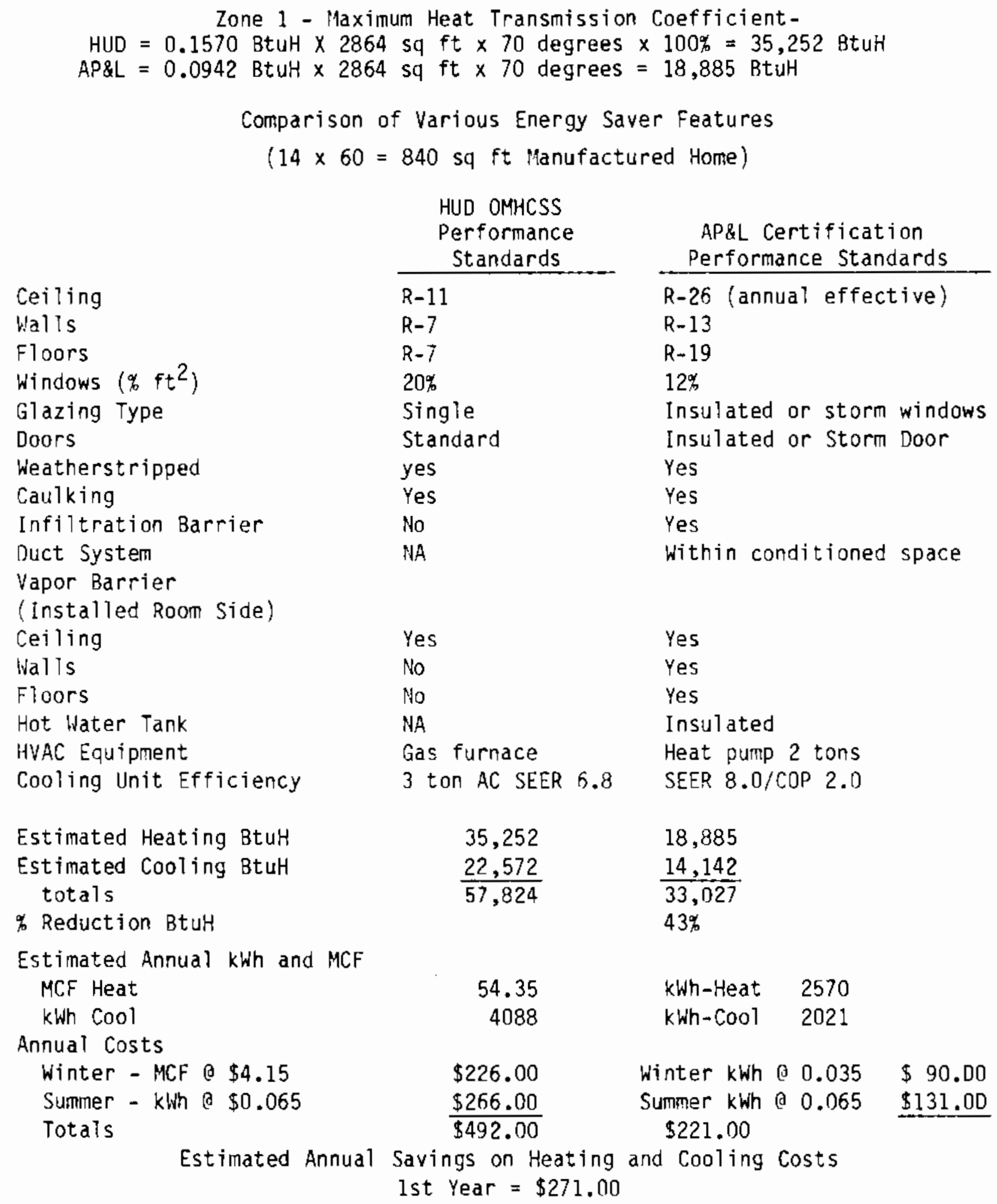

(a) Based on $75^{\circ} \mathrm{F}$ summer - $70^{\circ} \mathrm{F}$ winter ambient indoor temperature. 
The costs and savings associated with the package in Table A.1, as estimated by AP\&L, are presented below in Table A.2. The package has a simple payback period of about 4 years.

Current Program Status

The AP\&L program is currentiy underway and has experienced limited success. The major problems encountered thus far center around dealer resistance to participation. Specific problems have been:

TABLE A.2. Estimated Package Cost and Energy Savings

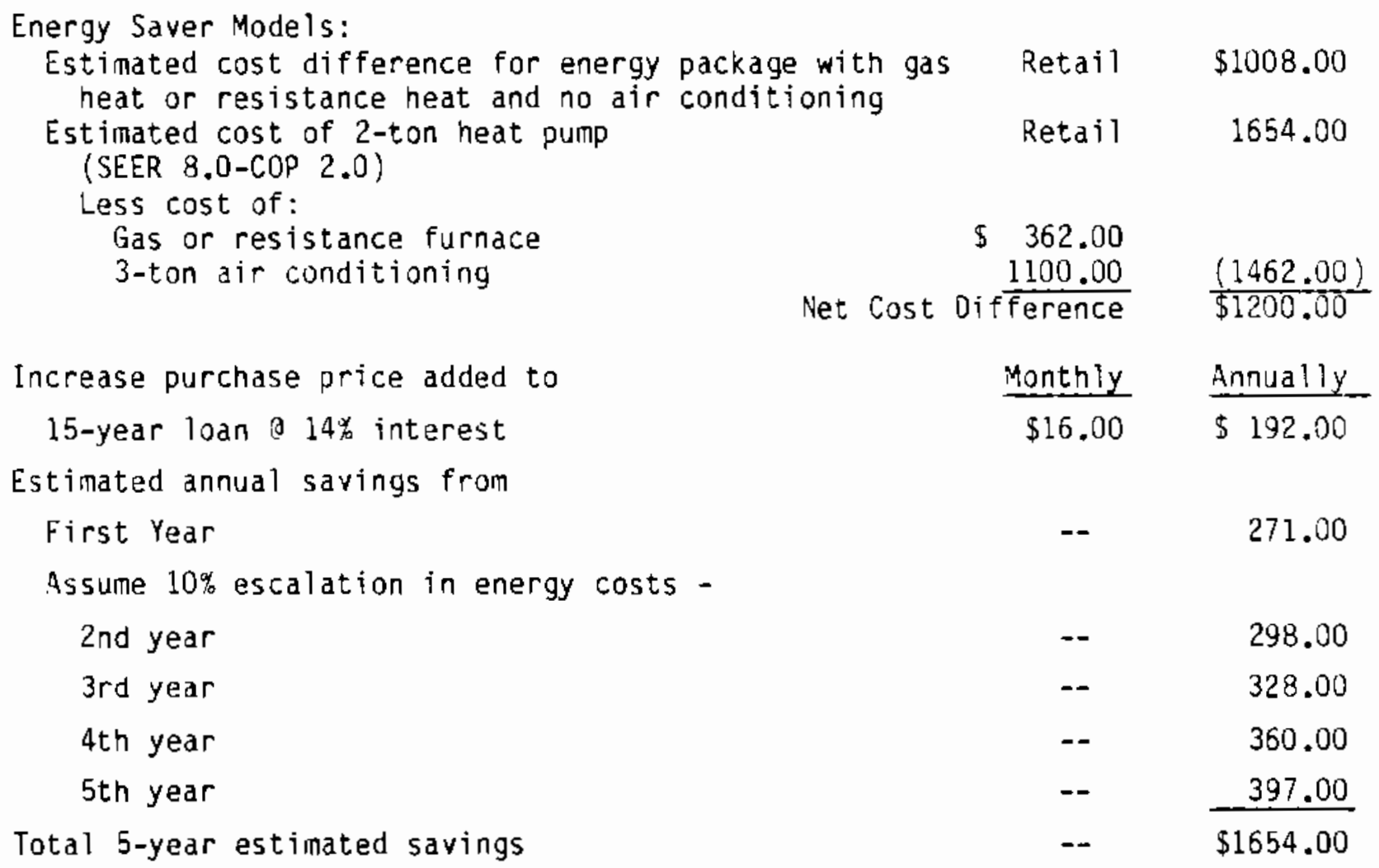

Note: A. If customer chooses to finance the added cost for energy efficiency, the savings should offset the additional cost of principal and interest.

B. As shown, the total principal amount would be realized in savings in less than 4 years. 
1. The energy saving package adds an estimated $\$ 2800$ total to the price of the home. Dealers contend that this increase discourages too many potential sales.

2. Dealers are expected to inventory and bear all related costs of the heat pump equipment.

AP\&L is seeking solutions to each problem. The cost problem is being approached through promotional appeals. Because the use of the heat pump eliminates the need for air conditioning equipment, AP\&L contends that air conditioning costs $(\$ 1462,00)$ can be deducted from the package cost for promotional purposes, resulting in an actual incremental cost of approximately $\$ 1338$ and a resulting payback of 3 to $3-1 / 2$ years. (Note: the package itself still adds $\$ 2800$ to the homes base prices.)

The second problem mentioned above is more difficult to solve. The HUD requirements state that the home must leave the manufacturers plant with an indoor furnace installed. Currently, AP\&L recommends a Coleman Model because it can be easily converted to a heat pump. However, parts for conversion and the external equipment must be stored at the dealers sales location (hence the problein). AP\&L is investigating the possibility of allowing dealers to arrange the heat pump installation at the setup site through independent heat-pump sales outlets and thus eliminating the need for dealers to carry heat pump equipment as inventory which results in costs to them.

\section{Documentation}

Arkansas Manufactured Housing Association and Arkansas Power and Light Company, A Marketing Program for Manufactured Housing, (undated). 


\section{A.3 Program Title Energy Qualified (EQ) Home Program \\ Program Sponsor Owens-Corning Fiberglas Corporation \\ Program Contact Mr. Glenn J. Singer \\ Manager, Product and Market Development \\ Owens-Corning Fiberglas Corporation \\ Fiberglas Tower \\ Toledo, Ohio 43659 \\ (419) $248-8000$}

\section{Program Description}

The Owens-Corning EQ program is probably the single most widely accepted and utilized energy conservation marketing program in the manufactured home industry today. The EQ program is targeted toward both manufacturers and dealers, and all aspects of the marketing mix from the product itself to advertising, sales promotion and selling tools.

Under the EQ program, the country is to divided into three zones. The zones correspond to the HUD thermal zones with the exception of an additional third zone for extreme winters. The zones are:

- Zone 1 - covers the southern portion of the U.S. and is consistent with HUD Zone 1 territories.

- Zone 2 - in general, covers the middle and northern coastal parts of the U.S. Cities included in Zone 2 are Harrisburg, Pennsylvania, South Bend, Indiana, and all of the states of Washington, Oregon and Idaho.

- Zane 3 -covers the extreme northern central and Atlantic areas of the U.S. Included are the cities of Bismark, North Dakota, Milwaukee, Wisconsin, and Portland, Maine and the State of Alaska.

A key element of the EQ program is a component comparisons chart developed by Owens-Corning with the aid of a proprietary computer model. The components of an illustrative manufactured home built to HUD thermal standards are compared to those of a similar home built to the EQ producing standards and are presented in Table A.3. 
TABLE A.3. HUD and Owens-Corning EQ Comparison Components

\begin{tabular}{cc} 
HUD Thermal & EQ Therma 1 \\
Standards & Standards \\
\hline
\end{tabular}

Wall Construction

$\begin{array}{lll}\text { Zone } 1 & 2 \mathrm{ft} \times 4 \mathrm{ft} & 2 \mathrm{ft} \times 4 \mathrm{ft} \\ \text { Zone } 2 & 2 \mathrm{ft} \times 4 \mathrm{ft} & 2 \mathrm{ft} \times 4 \mathrm{ft} \\ \text { Zone } 3 & 2 \mathrm{ft} \times 4 \mathrm{ft} & 2 \mathrm{ft} \times 6 \mathrm{ft}\end{array}$

Wall Insulation

Zone 1

$R-7$

$R-11$

Zone 2

$\mathrm{R}-11$

$R-13$

Zone 3

R-11

$R-19$

Ceiling Insulation

$\begin{array}{lll}\text { Zone } 1 & R-14 & R-25 \\ \text { Zone } 2 & R-14 & R-25 \\ \text { Zone } 3 & R-14 & R-28\end{array}$

Floor Insulation

Zone 1

$R-7$

$\mathrm{R}-14$

Zone 2

R-11

$R-14$

Zone 3

$R-11$

$R-19$

Window Grazing

$\begin{array}{lll}\text { Zone } 1 & \text { Single } & \text { Double } \\ \text { Zone } 2 & \text { Double } & \text { Double } \\ \text { Zone } 3 & \text { Double } & \text { Double }\end{array}$

Doors

$\begin{array}{lll}\text { Zone } 1 & \text { Standard } & \text { Upgraded Front, } \\ \text { Zone } 2 & \text { Front and } & \text { Standard } \\ \text { Zone } 3 & \text { Rear } & \text { Rear }\end{array}$

Owens-Corning claims that the EQ components are selected to utilize a systems approach to energy efficiency by combining energy-saving features in the most effective way to reduce heating and cooling costs. Estimated heating 
and cooling cost comparisons prepared by Owens-Corning are shown in Table A.4. The figures presented in Table A.4 are used by dealers to illustrate to potential customers the savings potential of purchasing an EQ home.

The EQ program includes elements directed at dealers, manufacturers, and customers each of which is discussed below.

Dealers. In addition to cost/savings charts, there are a variety of promotional and sales incentives for dealers. They include:

- outdoor EQ billboards

- banner displays

- newspaper advertisement "repro" kits

- customer literature and literature display

- a flip chart presentation for potential buyers

- pressure sensitive labels and danglers for in-home, point-of-display attention

- open house brochures

- buttons, T-shirts, pens, hats, etc.

A11 but the last items are provided at no charge to the dealer. Other incentives and benefits include:

- Reward Points - which are awarded at 100 points for each EQ home sold up to 600 points. The points are then redeemed by dealers for prizes.

- Advertising Benefits - dealers benefit from Owens-Corning corporate advertising which includes the $E Q$ or Pink-Panther Logos.

- Program members receive a commemorative plaque and official EQ certificate when they are "inducted" into the program and local media are notified.

Manufacturers. While important in terms of support, especially where the manufacturers have their own dealer system (e.g., Moduline and Lamplighter 
TABLE A.4. HUD and OCF EQ Estimated Heating and Cooling Costs Comparisons (1983)

Estimated Annual Heating and Cooling Costs

\begin{tabular}{|c|c|c|c|c|c|}
\hline $\begin{array}{r}\text { Natu } \\
\text { Heat/ } \\
\text { Co } \\
\end{array}$ & $\begin{array}{l}\text { Gas } \\
\text { ctric } \\
\text { ig } \\
\end{array}$ & $\begin{array}{l}\text { Ele } \\
\text { Hea }\end{array}$ & ic & $\begin{array}{r}\text { Electric } \\
\text { Heat } \\
\text { Electric } \\
\end{array}$ & $\begin{array}{l}\text { esistance } \\
\text { and } \\
\text { Cooling }\end{array}$ \\
\hline HUDO & EQ & HUD & $E Q$ & HUD & $E Q$ \\
\hline$\$ 488$ & $\$ 383$ & $\$ 465$ & $\$ 370$ & $\$ 680$ & $\$ 517$ \\
\hline 457 & 351 & 414 & 327 & 616 & 464 \\
\hline 539 & 427 & 562 & 446 & 707 & 537 \\
\hline 544 & 425 & 604 & 469 & 881 & 650 \\
\hline 339 & 239 & 301 & 217 & 438 & 301 \\
\hline$\$ 916$ & $\$ 737$ & $\$ 1141$ & $\$ 916$ & $\$ 1733$ & $\$ 1383$ \\
\hline 535 & 416 & 670 & 516 & 1119 & 841 \\
\hline 616 & 480 & 551 & 435 & 908 & 692 \\
\hline 722 & 578 & 777 & 623 & 1217 & 966 \\
\hline 848 & 653 & 881 & 679 & 1455 & 1113 \\
\hline 369 & 259 & 256 & 182 & 461 & 322 \\
\hline 539 & 422 & 515 & 405 & 849 & 654 \\
\hline
\end{tabular}

Double wide Units

\begin{tabular}{|c|c|c|c|c|c|c|c|}
\hline $\begin{array}{l}\text { HUD } \\
\text { Zone } 1\end{array}$ & $\begin{array}{l}\text { Atlanta, GA } \\
\text { Charlotte, NC } \\
\text { Dallas, TX } \\
\text { Little Rock, AR } \\
\text { Sacramento, CA }\end{array}$ & $\begin{array}{r}\$ 721 \\
692 \\
721 \\
764 \\
482\end{array}$ & $\begin{array}{r}\$ 492 \\
465 \\
552 \\
556 \\
323\end{array}$ & $\begin{array}{r}\$ 675 \\
598 \\
751 \\
857 \\
424\end{array}$ & $\begin{array}{r}\$ 477 \\
422 \\
578 \\
615 \\
295\end{array}$ & $\begin{array}{r}\$ 1051 \\
940 \\
996 \\
1312 \\
630\end{array}$ & $\begin{array}{r}\$ 661 \\
597 \\
697 \\
860 \\
403\end{array}$ \\
\hline $\begin{array}{l}\text { HUD } \\
\text { Zone } 2\end{array}$ & $\begin{array}{l}\text { Bismark, NO } \\
\text { Denver, CO } \\
\text { Harrisburg, PA } \\
\text { Minneapolis, MN } \\
\text { Portland, ME } \\
\text { Portland, OR } \\
\text { South Bend, IN }\end{array}$ & $\begin{array}{r}\$ 1277 \\
743 \\
901 \\
1017 \\
1238 \\
548 \\
782\end{array}$ & $\begin{array}{r}\$ 1003 \\
586 \\
678 \\
789 \\
911 \\
381 \\
591\end{array}$ & $\begin{array}{r}\$ 1601 \\
934 \\
803 \\
1101 \\
1293 \\
379 \\
749\end{array}$ & $\begin{array}{r}\$ 1256 \\
733 \\
612 \\
854 \\
953 \\
269 \\
569\end{array}$ & $\begin{array}{r}\$ 2416 \\
1552 \\
1347 \\
1719 \\
2131 \\
686 \\
1242\end{array}$ & $\begin{array}{r}\$ 1884 \\
1196 \\
989 \\
1320 \\
1553 \\
474 \\
925\end{array}$ \\
\hline
\end{tabular}

Owens-Corning provides the following qualification on the use of these figures. "Actual energy use and costs for heating and cooling (if applicable) will vary from these estimates. The above comparisons are examples only and will not be the same for the home you buy. The estimated heating and cooling expenses are based upon average utility rates (January 1 - December 31, 1982) for each utility by city. The calculation procedure is simplified and the results are an approximation. Specific assumptions were made relative to family size, living habits, thermostat set points, weather patterns, air infiltration rates, workmanship, and fuel costs. Since these factors will vary, no actual heating and cooling costs can be predicted for any specific home. These estimates do not include the cost of using lights, appliances, and water heaters and therefore are not estimates of the total utility bill." 
dealers), the program emphasis is on dealers. However, manufacturers are also encouraged to join the program because of the following potential benefits:

- market share increases through production of homes consumers are demanding.

- benefit of Owens-Corning advertising.

- commemorative plaque and EQ certificate upon membership with local media notification.

Manufacturers with their own dealer network are used by Owens-Corning as an agent through which the EQ program is administered. Owens-Corning works directly with the manufacturer who in turn induct their dealers into the program. The benefits and support are the same as listed for dealers who participate independently.

Consumers. Owens-Corning claims the buyers of EQ-designated homes benefit in a number of ways including the following:

- The energy cost savings for both heating and cooling over the period the consumer owns the home.

- A $\$ 100.00$ rebate is available at specially designated tines with the purchase of a single or multi-section EQ home. The idea behind the rebate is to demonstrate to consumers that they will realize savings from an EQ home right from the time of purchase.

- The Energy Qualified Home Certificate is given to the consumer at the time of sale. The certificate details the energy-efficiency characteristics of the home and can potentially become an important resale asset.

- Lenders are becoming more willing to reduce normal debt-to-income ratio requirements for the purchase of energy efficient homes (see Section 4.1). Thus, some consumers are able to qualify for loans who otherwise would not have. 
- OCF contends that consumers spend less time in information search as the EQ seal insures that specific thermal standards have been met. Consumer trust is increased and perceived risks decreased as a result of the EQ seal.

Because of their visibility and customer contact, Owens-Corning feels that the dealers are the key component in the consumer decision process. Most emphasis is therefore placed on dealers in terms of incentives and support. Emphasis on manufacturers varies based upon their sales network arrangement.

\section{Current Program Status}

OCF believes that the Energy Qualified home program has been successful to date. The combination of merchandising tools, computer-based cost/savings estimates and other support have proven to be effective in increasing sales of energy-efficient homes. The degree of consumer recognition of the EQ and Pink Panther Logos is also of great importance in achieving consumer recognition and reducing perceived risks. One manufacturer and two dealers who sell EQ homes were contacted for this study. Their comments and observations are contained in Sections A.3.1-A.3.3.

\section{A.3.1 Wausau Homes}

Contact: $\mathrm{Mr}$. Paul Ott

Marketing/Sales Manager

Wausau Homes

P.0. Box 1204

U.S. Hwy 51 South

Wausau, Wisconsin 54401

(715) 359-7272

\section{Program Comments}

Wausau homes is a manufacturer that has joined the EQ program. It also encourages its dealers to participate in the program. Merchandising tools and sales aids are provided at no charge to Wausau by OCF, who distribute them to their (independent) dealers.

The heart of the EQ program is the computer model which estimates the cost of heating and cooling a particular home. The model is estimated by OCF to be accurate within a plus or minus $6 \%$ variance and Wausau's experience has shown 
actual usage/cost to be within that variance to date. Wausau believes the second element contributing to the EQ program success is the EQ certificate given to the home buyer. The certificate explains exactly what materials and energy-efficiency features went into the homes' construction (insulation, glass, lumber etc.) and includes a computer printout attachment containing expected annual energy costs. According to wausau, the certificate has proven to be a valuable asset to consumers for resale of the home.

Other marketing tools used by Wausau Homes include:

- Occasional sales or discounts on the purchase of energy-efficient options. A typical promotional campaign could consist of advertising and a $50 \%$ price reduction of such options. This practice has proven successful in generating sales of energy efficiency options in the past.

- Wausau Homes encourages all of its dealers to set up an "Energy Room" in their demonstration homes. A cut-away wall reveals the increased levels of insulation and other energy-saving materials such as energy shield sheathing which would otherwise be unseen. This sales tool is designed to sell energy efficiency as a visible, value-added feature inuch like upgraded cabinets or a fireplace. The room can be resealed for later sale of the home.

Wausau homes' experience with the EQ program has been favorable and profitable. Wausau Homes feels that the Owens-Corning model is the most sophisticated in use, and they expect to continue membership in the EQ prograin.

\section{A.3.2 McCullough Homes Center}

Contact: Mr. Mac McCullough 2500 West Broadway Moses Lake, Washington 98837 (509) 765-1888

\section{Program Comments}

McCullough's sales representatives find that their manufactured home consumers are very interested in energy efficiency and consistentiy ask about R-values for insulation. Being able to use the EQ home component chart which 
details the construction standards of the EQ home, and its energy cost/savings potential, is an effective sales tool and an attractive feature of the EQ program. McCullough Homes Center sells only EQ homes under the Marlette and Kit brand names.

\section{A.3.3 Acme Quality Homes}

Contact: Mr. Bob Urban

7821 Martin way

Olympia, Washington 98506

(206) 456-8971

\section{Program Comments}

Acme believes that Owens-Corning has done an excellent job in providing a merchandising package to the dealer. The advertising which is done by OwensCorning is believed to be the key to consumer awareness. Consumers come into the sale with an interest and awareness of energy efficiency. Consumers are nost concerned with "R-values" for insulation regardless of whether they understand what an R-value is. The most useful merchandising tool has been the "Estimated Heating and Cooling Cost Comparisons" Chart (Table A.4). "Experience has shown that the more tangible one can make energy efficiency, the more it will sell--and money costs and savings are tangible."(a) One suggestion for improvement of the cost comparison chart Acme would make would be the addition of more cities. Acme Homes uses Portland, Oregon because there are no estinates for any washington location.

\section{Concluding Remarks}

The Energy Qualified home program is generally well liked and accepted by the manufactured home industry. The level of support given by Owens-Corning is perceived to be excellent. It seems the cost/savings estimates and the institutional advertising are viewed as the key elements of the program. The advertising creates awareness and the cost/savings chart, serves as tangible evidence to help close the sale.

(a) Telephone conversation with Mr. Bob Urban of Acme Homes, February, 1985. 
Documentation

1. "Lenders Offering Special Financing for "Energy Qualified" Homes," Automation in Housing and Manufactured Home Dealer, p. 12, February 1985.

2. "Energy Qualified Home Promotion Includes Rebates, Return, Dealer Incentives," Automation in Housing and Manufactured Home Dealer, p. 34, July 1984 .

4. "Energy Promotion Offers Retail Incentive," Mobile/Manufactured Home ilerchandiser, p. 46, July 1984.

5. "Owens-Corning's Newest Promotion Features Energy-Qualified Homes," Mobile/"lanufactured Home Merchandiser, p. 28, November 1983.

6. "New 0-C "EQ" Plan llay Boost Mobile Sales," Automation in Homes and Manufactured Home Dealer, p. 1, September 1983.

7. Owens-Corning Fiberglas Corporation, Manufactured Housing Dealers Eneryy Qualified Home ierchandising Package, 1983. 


\section{A.4 Program Title Energy Efficient Manufactured Home Program \\ Program Sponsor State of Maine, Office of Energy Resources \\ Program Contact Mr. Bryan Kent \\ Maine Office of Energy Resources \\ State House Station 53 \\ Augusta, Maine 04333 \\ (207) 289-3811}

Program Description

The goal of this program is to reduce energy use, and therefore costs, in manufactured homes through voluntary consumer action. The vehicle to achieve this goal and implement the program is the Federal Solar Bank Fund which is administered through each state. The program began with the Office of Energy Resources entering a partnership with two manufacturers. The two companies agreed to build 10 manufactured homes each which met the program standards. The office of Energy Resources would then help market the homes by making a subsidy of $\$ 2828$ available to qualified buyers, which basically paid for the cost of the energy upgrade. A total of $\$ 56,560$ was inade available to buyers of these 20 homes through the Fund.

The home specifications required by the program are:

Framing

- $2 \times 6$ sidewalls

- $2 \times 6$ top and bottorn plates

- $2 \times 8$ floor joists

- 40 lb snow load (roof)

Insulation

- R-22 7 in. floor

- R-196 in. exterior wall

- polystyrene energy wrap

- R-38 12 in. ceiling

- draft gaskets on exterior wall receptacles and switches

- triple-glazed clad weather shield windows

- Taylor street thermo-doors

- 1-1/4 in. storin doors 


\section{Other Features}

- water-heater setback timer

- air exchanger

- home sited to take advantage of passive solar gain.

Heating cost estimates for 011 heat and electric baseboard heat were calculated for 2 cities representative of the thermal zones in Maine. The payback period for the package was estimated at 5 years. The cost estimates also included the thermal solar gain to be achieved through the siting requirements of the homes. These requirements were that $80 \%$ of the glazed surface of the home face south for all homes sited on lots or in parks.

The program was designed as a contest of sorts where eligibie buyers would enter their name for possible participation in the program. Up to 20 eligible recipients would be selected for the $\$ 2828$ subsidy. Statewide distribution of homes is one objective of buyer selection. Recipients also had to obtain financing commitments and certify their income in order to be selected. Other qualifications were:

- resident of Maine

- annual income of $\$ 28,000$ or less

- meet the siting requirement

- make their energy records available to the office of Energy Resources for one year

- make the home open to the public during specific periods of the marketing program.

\section{Current Prograin Status}

As of March 1985, 10 of the 20 homes built have been sold. The program's relative lack of success has been attributed to the little pronotion it received and the timing of its introduction. The manufactured home buying season in Maine basically ends in mid November. This program was introduced in December, 1984. The intention is to reintroduce the program in the spring of 1985, with appropriate promotion. 
Documentation

1. State of Maine, Office of Energy Resources, Demonstration Mobile Homes Energy Performances (Solar Bank), September 26, 1984.

2. Burlington Homes of New England, Inc., Solar Bank Subsidy sponsored by State of Maine Office of Energy Resources, October 22, 1984.

3. Burlington Homes of New England, Inc., The New Residential Interior Decor, January $1,1985$.

Contact at Burlington Homes, one of the two manufacturers of homes under the program.

Mr. Rick Erickson

Sales Manager

Burlington Homes of New England, Inc.

Route 26

0xford, Maine 04270

(207) $539-4406$ 
A.5 Program Title Consumer Oriented Booklets on llanufactured Home Energy

Several booklets produced by State Energy offices and other organizations are briefly discussed in this section. This approach to increasing awareness of energy efficiency and energy savings options has several desirable features, most important of which is low cost. For the owners of existing manufactured homes, the booklets are educational and informational in nature and also take a "how-to" approach to low/no cost retrofitting. In addition to retrofitting, the booklets provide the new manufactured home shopper tips on what features to look for and what questions to ask to find energy-efficient homes. Four booklets are discussed.

\section{A.5.1 The Energy-Efficient Manufactured Home in Texas}

This booklet was produced by the Energy Efficiency Division of the Texas Public utility Commission. The booklet is organized around the following sections:

Section 1: Energy-Saving Practices

Section 2: Energy Conservation lleasures (such as orientation, shading, skirting, weatherization, insulation, energy saving windows and doors) and Renewable Resource iteasures (including how to read and interpret Energy Guide Appliance labels)

Section 3: Energy Savings, Costs and Payback Estinates for Practices and Measures in Five Texas Cities

Section 4: Other Energy Considerations for Owners and Buyers of Manufactured Homes; Tax Credits, Building Codes, What to Look for when Buying a New Home

The booklet also contains a questionnatre on the consumer's perception of the quality and usefulness of the booklet. This technique can be a good source of feedback to modify a booklet. There are also telephone numbers and addresses of agencies which consumers can contact for inore information about a manufactured home and energy efficiency. 
Program Contact: Public Utility Commission of Texas

Energy Efficiency Division

7800 Shoal Creek Blvd.

Suite $400 \mathrm{~N}$

Austin, Texas 78757

(512) $458-0100$

Documentation: Public Utility Commission of Texas, Energy Efficiency Division, The Energy Efficient Manufactured Home in Texas, February 1982.

\section{A.5.2 The South Dakota Mobile Home Energy Savings Guide}

This consumer booklet is distributed by the South Dakota Office of Energy Policy. Its contents were developed by the New Mexico Energy Institute at the University of New Mexico. The booklet addresses the unique problems with energy efficiency in manufactured housing and discusses low/no cost steps residents can take to save energy and money. This booklet is directed at both new and older home buyers and/or owners. The contents of the booklet are:

The Natural System ... The Sun, Color and Orientation, Window Management, the Wind, Solar Greenhouses

The Physical System... The Building Envelope, Caulking and Weatherstripping, Insulation, Storm Windows, Skirting, Heating, Thermostats, Fireplaces, Cooling, Hot Water

The Human System... Behavior and Lifestyle Characteristics Which Affect Energy Use

Action Alternatives... Specific Energy Saving Actions One Can Take Including Their Cost, Energy Savings, and Payback Periods for Selected Cities in South Dakota

A Solar Greenhouse for

Your Mobile Home... How to Build a Solar Greenhouse

This booklet takes a systems approach to manufactured home energy efficiency. Each subsystem is described individually and then in terms of how it fits in with the total energy use system of the home. 
Program Contact: South Dakota Office of Energy Policy

Documentation: South Dakota Office of Energy Policy, The South Dakota Mobile Home Energy Savings Guide, Fall 1980.

\section{A.5.3 An Energy Diet for Mobile Homes, An Owners Guide to Saving Money}

This booklet was developed by the National Center for Appropriate Technology. It describes in some detail how energy efficiency problems may arise and then proceeds to demonstrate various low/no cost methods of correcting the problem in a prescriptive, "how-to" format. This booklet is fairly comprehensive in scope and is primarily directed toward retrofitting homes. The contents include:

- Existing

- How Your Mobile Home Wastes Energy

- What you Can Do: Putting Your Mobile Home on an Energy Diet

- The Foundation

- The Floor

- The Walls

- The Ceiling

- The Heating System

- The Cooling System

- The Hot Water Heater

- A Conservation Checkijst

- Resources.

The conservation checklist presented at the end of the booklet presents no/ low cost tips the reader can easily take to improve energy usage. The tips cover the following topics; During the Heating Season..., During the Cooling Season..., When Cooking..., In the Laundry..., Hot Water..., and Your Refrigerator. The "Resources" section Tists Books, Booklets, Magazines and Wholesale Suppliers of Weatherization Products. These last two sections mentioned would seem to be very useful to consumers looking to reduce energy use through behavior changes or home improvements/modifications. One drawback of this booklet is that it is not geographically targeted and thus does not give specific recommendations for a particular climate zone, nor does it give cost/energy savings or payback information. 
Program Contact: National Center for Appropriate Technology Box 383

Butte, Montana 59702

Documentation: National Center for Appropriate Technology, An Energy Diet for Mobile Homes, An Owners Guide to Saving Money, 1982.

\section{A.5.4 Energy Conservation Ideas for Mobile Homes}

This booklet was developed by the National Rural Electric Cooperative Association. It is a fairly comprehensive examination of manufactured home energy use patterns involving the home itself, the site, the macro- and microclimates, and their interaction effects. The emphas is is on identifying and explaining low technology (low/no cost) conservation measures which the home occupant can implement. The general areas covered are siting, the building envelope, manufactured home additions or alterations, and internal loads and mechanical system alterations. The specific organization is:

- Siting for Energy Conservation

- Mobile Home Construction

- Energy Problems

- Energy Transfer/Air Infiltration/Moisture Penetration

- Vapor Barriers

- Insulation Materials

- Infiltration Barriers/Exterior Sheathing

- Considerations in Mobile Homes Envelope Retrofits

- Foundation/Floor Problems and Solutions

- Windows and Doors

- Infiltration

- Internal Loads

- Appliances

- Lighting

- Bathrooms

- Mechanical Systems

- Equipment Modifications

- Zoning

- Setbacks 
- Replacement Systems

$$
\begin{aligned}
& \text { heat Pumps } \\
& \text { Radiant Heating } \\
& \text { Solar Energy Systems } \\
& \text { - Other Mechanical System Options }
\end{aligned}
$$

- Implementation.

This book describes energy use and efficiency considerations. It is reasonably complete and offers the reader a fairly in-depth discussion of various conservation options. The level of detail may, however, be beyond the needs of the average consumer.

Program Contact: Lowell J. Endahl, Manager

National Rural Electric Cooperative Association

Energy Research and Development 1800 Massachusetts Ave. N.W. Washington, D.C. 20036 (202) 857-9599

Documentation

1. National Rural Electric Cooperative Association, Energy Conservation ideas for Mobile Homes, prepared by Burt Hill Kosan Rittelman Associates, October 1980 . 


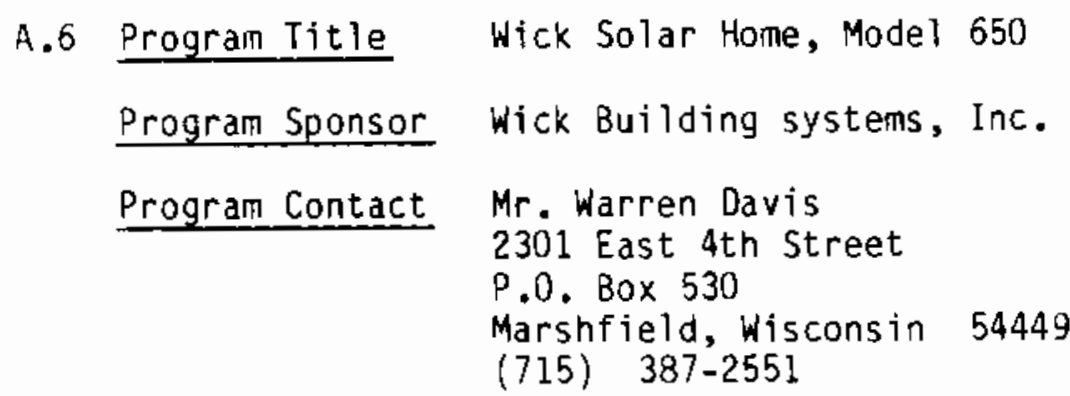

Program Description

This effort basically involved designing, constructing, and marketing an energy-efficient addition to the Wick product line, namely the Solar Model 650. The home's final design consisted of the following energy features:

- 2 in. $x 6$ in. sidewall construction with a continuous foan core wrap giving a calculated $R-20$ insulation level

- a roof system incorporating three layers of R-11 batt insulation with a gap or barpier resulting in a total of R-33 insulation

- $2 \mathrm{in.} \times 10 \mathrm{in}$. floor system so that the hone could be placed on a foundation

- two layers of R-11 batt insulation with foil facing up for an R-22 floor insulation level

- triple-glazed windows, storm doors on both entrances with airlock entries, and gaskets used on the inside of the receptacle and switches.

The home included $89.25 \mathrm{ft}^{2}$ of direct-gain glazing on the south side of the model. No glass appears on the east or west walls and oniy $9.61 \mathrm{ft}^{2}$ of glass on the north. Both entries are glazed and located on the south side. Foilbacked curtains help prevent heat loss in the winter and heat gain in the summer. There is little or no thermal storage in the home other than the intrinsic heat capacity of the interior construction and furnishings. The root/ceiling trusses are pitched 60 degrees to the south, providing a surface for possible future installation of active solar collectors or photovoltaics. The homes use a gas-fired, forced-air furnace as the backup auxiliary heating source. 
The wholesale price of this single wide home was $\$ 15,872$ which included $\$ 370$ for utility connections and $\$ 2281$ for the conservation measures. This price represents an $18.9 \%$ increase in the cost to dealers of this home. Retail price differences between the model 650 and others was even greater because the home required a treated wood foundation for proper siting. The siting added an additional $\$ 3220$ to the retail cost of the home. Energy savings were estimated using the SERI-Residential Energy Simulator computer-based model and the payback period was estimated at 9.48 years.

Current Program Status

The solar model 650 has been discontinued. Several factors account for its lack of market acceptance, the most important of which was its fairly high price. In addition, most consumers found the long payback period to be unacceptable, given the average tenure of manufactured home residents which wick estimates to be 3 to $3-1 / 2$ years. The model 650 was also found to be overly complex in terms of its features. Sales people and consumers were both overwhelmed with the amount and detail of information required to digest, which created resistance on the part of sales people, and information overload on the part of the consumer. Lastiy, legal problems arose over the accuracy of energy cost predictions by Wicks computer model in comparison to owners' actual energy costs.

Documentation

1. Solar Energy Research Institute, Passive Solar Manufactured Buildings: Design, Construction and Class B Results, SERI/SP-271-2059, Chapter 5, December 1984. 


\section{A.7 Program Title SAVE: System to Analyze Value and Energy \\ Program Sponsor Ford Motor Company \\ Program Contact Ford Glass Division \\ 300 Renaissance Center \\ P.0. Box 43343 \\ Detroit, Michigan 48243 \\ $1-800-521-6345$}

\section{Program Description}

This program was designed around Fords "Sunglas for use in any structure type, new or existing. Palm Harbor Homes of Texas is one manufacturer that uses "Sunglas" in its "Energ-Meiser" line of manufactured homes. Sunglas ${ }^{\circledR}$ contains an "atoms-thick" low emittance coating which resists heat transfer to the lower temperature side of the pane. Thus, in the winter when the homes inside is warmer than outside, heat is held in the home rather than allowed to radiate out of the window. The opposite effect occurs in the summer.

The marketing progran is designed to help the design professional in the evaluation of various glazing alternatives for all types of structures. The program compares operating costs, required equipment size, initial investment and present worth for up to 8 different glasses. The program is initiated by a Jesigner completing a "Data Input Form" which is mailed to Ford Glass Division. The analysis is conducted and results are then mailed back to the designer.

The inputs required are:

- Orientation

- Wall/glass Area

- Number of Elevations

- Floor Area

- Building Parameters

- Glass Alternatives

- Occupancy Expectations

This data is then fed into the computer model and the following outputs are obtained:
- Operating Temperatures

- Light Leveis

- Hechanical Equipment Costs

- Tax/Interest Rates

- Energy Costs
- Shading Devices 
APPENDIX B

MANUFACTURERS WHO SELL HOMES IN THE NORTHWEST 
APPENDIX B

MANUFACTURERS WHO SELL HOMES IN THE NORTHWEST

Director of Marketing

Colville Tribe Log Homes

P.0. Box 328

Nespelem, Washington 99155

David C. Struck

Vice President, West

Champion Home Builders Company

5573 North Street

Dryden, Michigan 48428

Jerry Sullivan

Division Manager

Sequoia Homes

P.0. Box 70

Weiser, Idaho 83672

Director of Marketing

The Commodore Corporation

P.0. Box 578

Lebanon, Oregon 97335

Director of Marketing

The Commodore Corporation

28,00 Ordhard Avenue

P.0. Box 827

McMinnville, Oregon 97128

Director of Marketing

Fleetwood Enterprises, Inc.

P.0. Box 7638

3125 Myers Street

Riverside, California 92523

Director of Marketing

Fuqua Homes, Inc.

Division of Fuqua Industries, Inc.

Bend Division

P.0. Box 5579

Bend, Oregon 97701
Paul Frederickson

Marketing Manager

Glen River Industries, Inc.

P.0. Box 810

1703 Lum Road

Centralia, Washington 98531

Bruce Stoyer

General Manager

Goiden West Homes

Albany Division

2500 South Walnut

Albany, Oregon 97321

Bob Payne, General Manager

Guerdon Industries, Inc.

Subsidiary of Wood Brothers Homes, Inc.

P.0. Box 5188

Whitney Station

Boise, Idaho 83705

Paul Hoag

General Manager

Guerdon Industries

Subsidiary of wood Brothers Homes, Inc.

1200 Willco Road

Stayton, Oregon 97383

Director of Marketing

Kaufman and Broad Home Systems, Inc. 5500 Federat Way

P.0. Box 5569

Boise, Idaho 83705

Richard McMillan Marketing and Sales Manager

Kentwood Homes, Inc.

316 Ellingson Road

Algona, Washington 98002 


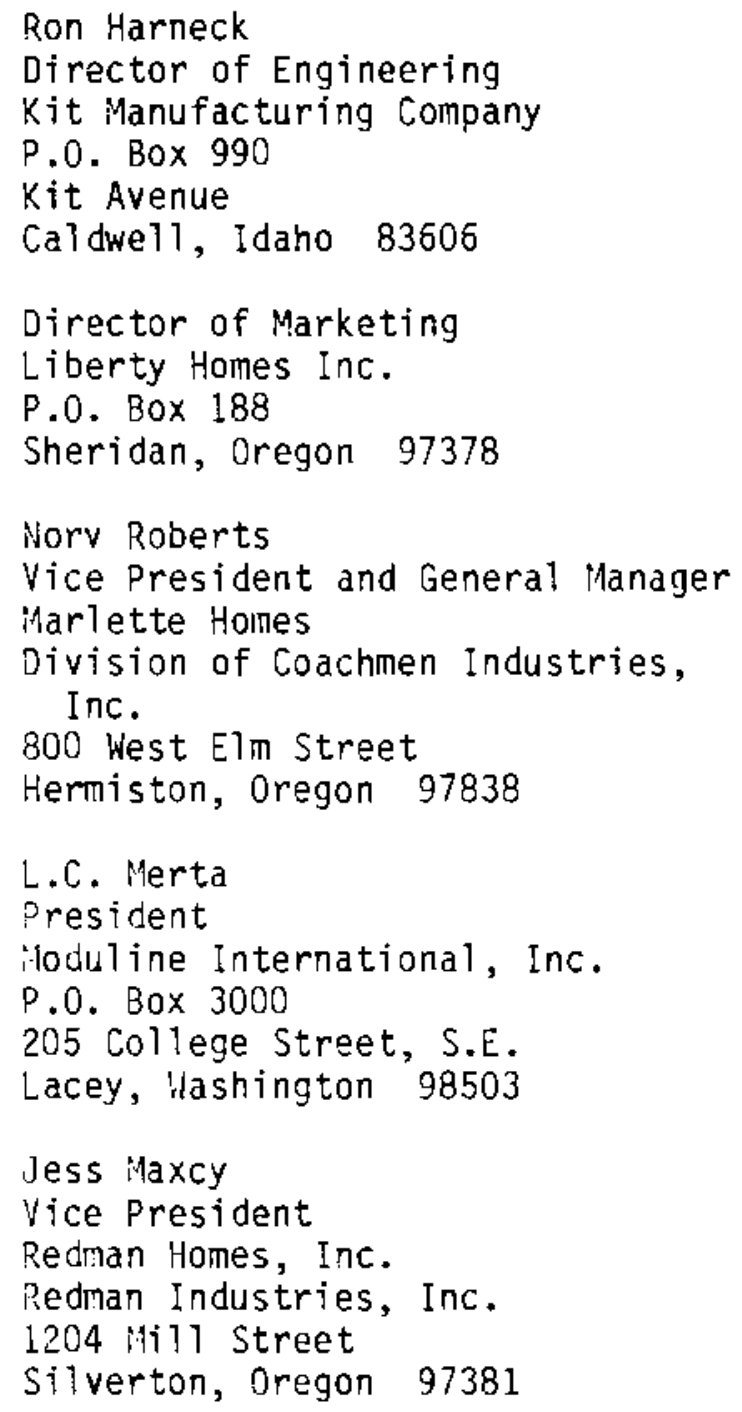

Ron Harneck

Director of Engineering

Kit Manufacturing Company

Kit Avenue

Director of Marketing

Liberty Homes Inc.

P.0. Box 188

Norv Roberts

Vice President and General Manager

Marlette Hoines

Division of Coachmen Industries, Inc.

800 West Elm Street

L.C. Merta

President

iloduline International, Inc.

P.0. Box 3000

205 College Street, S.E.

Lacey, ilashington 98503

Jess Maxcy

Pedran Industries, Inc.

Silverton, oregon 97381

Paul $K$. Haggard

President

Rustic Log Structures, Inc.

5829 South 140th Street

Seattle, Washington 98168

Susan Sherman

Marketing Manager

Silvercrest Industries, Inc.

2450 Progress Way

Woodburn, Oregon 97071

Director of Marketing

Skyline Corporation

2520 By-Pass Road

Elkhart, Indiana 46515

Ken Bilgrien

General Sales Manager

Wick Building Systems Inc.

P.0. Box 296 or 429

1823 Robertson Road

Moberly, Missouri 65270

Milton Barningham

General Manager

Nashua Homes Corporation of Idaho

P.0. Box 3449

200 North Maple Grove Road

Boise, Idaho 83707

Director of ilarketing

Fleetwood Homes of Washington, Inc.

211 5th Street

P.0. Box 250

Woodland, Washington 98674 
NORTHWEST MANUFACTURED HOUSING TRADE ASSOCIATIONS 
NORTHWEST MANUFACTURED HOUSING TRADE ASSOCIATIONS

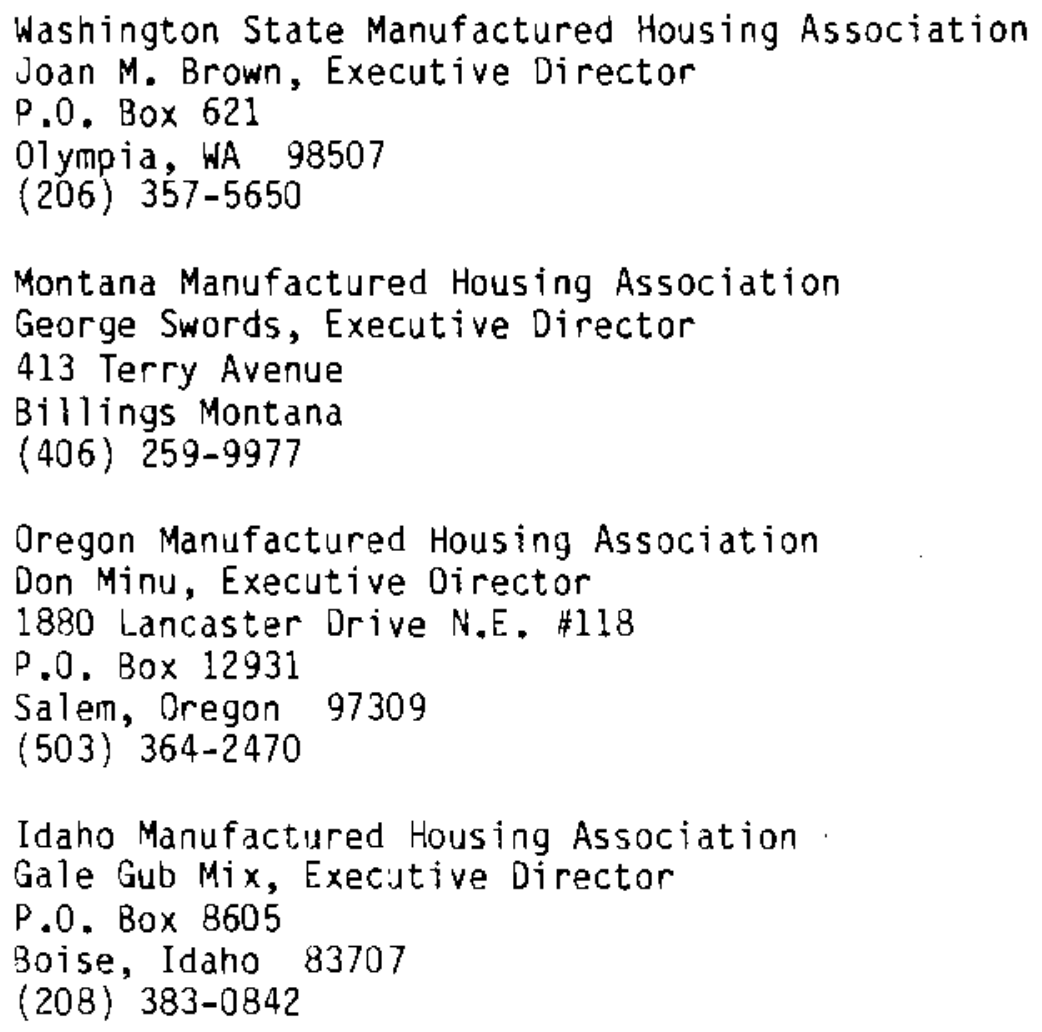



4

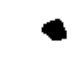

\author{
APPENDIX D \\ COVERLETTER AND SAMPLE RESPONSE FORM USED TO COLLECT HOME ANO OPTIONS \\ SALES DATA FROM NORTHWEST MANUFACTURERS
}




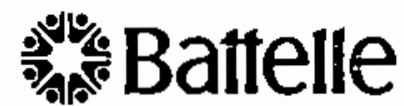

Pacific Northwest Laboratories P.O. Box 999

Richland, Washington U.S.A. 99352

Telephone (509)

$376-5595$

Telex $15 \cdot 2874$

February 27,1985

Dear

Battelle, Pacific Northwest Laboratory has recently begun a study for the Bonnevilie Power Administration on HUD-Code (mobile) home energy efficiency in the Northwest region (Idaho, Oregon, Washington, and western Montana). As part of the study, we are writing to all Northwest MUD-Code home manufacturers to obtain information relating to their product lines and energy efficiency. Specifically, we are interested in the following subjects for the Northwest region on ly:

1) a description of the energy efficiency characteristics in the basicpackage home you offer consumers and the upgrade packages from which consumers can choose

2) an estimate of the cost of each upgrade package to the consumer

3) the estimated energy-savings potential of each optional package if such information is available

4) numbers and percentage of your homes that are built with each optional package (including homes built to the HUO minimum thermal requirement or your own basic package), broken down by homes that are custom ordered by consumers and homes that are ordered by your dealers to be sold off their sales lots

5) a description of your product line(s), including floor plans, schematics and suggested retail prices

6) numbers and percentage of your homes with electric resistance, heat pump, natural gas, and $L P G$ heating 
7) any information you have on HUD-Code home buyer characteristics or profiles for the Northwest

8) any ideas you have that could be used to enhance consumers' interest in and propensity to purchase energy conservation options or otherwise improve the market for such options

9) an estimate of the number of units delivered within the Northwest region, by county over the past several years (or alternatively, a copy of form 302 supplied to NCSBCS for the past several years).

We have enclosed a sample form to aid your response. If you choose to use the form, please use a separate page form for each model in your product line.

Any information you supply beyond the forms need not be formally assembled. Please be assured that all information you supply us will be treated confidentially. Our project reporting will be presented in a summary format only, and the responses of individual manufacturers will not be identified. We anticjpate that our final report will be available for outside distribution. Please indicate if you would like to receive a copy.

I greatly appreciate your help and would like to receive this information from you by March 10 (but responses are certainly welcome after that date). Please do not hesitate to call if you have any questions or if I can be ô service to you.

Sincerely,

Bryan L. Mohler

Market Research Scientist

BLM/dy

Enclosure

cc: RC Adams 
Sample Resource Form (One Per Model)

Manufacturer

Model Name

Suggested Base Retail Price $\$$

Total Sales (units) 1984

Custons

Dealer Floor

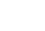

\section{Dimensions}

\% Glazed Surface $\%$

\section{Percent of this Model Sold by Heating Type}

- Electric Resistance

- Heat Pump

- Natural Gas

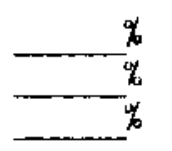

- LPG Heating

- Fuel 0il

- Other

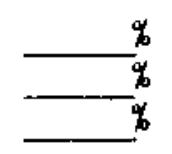

Potential

Energy

Savings

Typical Above

Retail the HUD-

Price Code Level

Your Basic

$\begin{array}{llll}\text { Sales Volume } & & \text { Glazing } \\ \text { Custom } & \text { Dloor } & \text { Wall Ceiling Floor of } & \text { of } \\ \text { Crdered Models R-Value R-Value R-Value Panes) }\end{array}$

Other Package Features

is lloine

\section{Energy Efficiency Upgrades}

Package A

Packag̣e B

Package $\mathrm{C}$

Package D 



\section{APPENDIX E}

INDOOR AIR QUALITY IN MANUFACTURED HOMES 


\section{APPENDIX E}

\section{INDOOR AIR QUALITY IN MANUFACTURED HOMES}

Indoor air quality (IAQ) is a potential problem with energy efficient housing because such housing frequently has low ventilation rates.(a) Consumer concerns and attitudes about IAO need to be considered when programs to increase residential energy efficiency are designed. The IAQ problem is of particular concern for programs seeking to improve the energy efficiency of manufactured housing because the plywood and particleboard used in the interior of manufactured homes are often bonded with a resin system or coated with a surface finish that emit formaldehyde. The health risks associated with potentially high formaldehyde levels have been the principal focus of recent research and policies directed at manufactured housing IAO issues.

BPA has targeted $I A O$ as it relates to energy efficient housing as an area of major programmatic interest. It has sponsored a variety of studies with the Lawrence Berkeley Laboratory, (b) prepared a comprehensive environmental impact statement (EIS) that emphasizes IAQ issued, (c) and prepared a consumer booklet. (d) The EIS contains detailed information on indoor air pollutants, pollutant sources, existing levels of particular pollutants including formaldehyde, and the health risks associated with various pollutants. The booklet summarizes information on pollutants of concern, possible health effects, sources of each pollutant in homes, and steps that can be taken to reduce exposure.

(a) The ventilation rate, usually expressed as air charges per hour (ACH), is the number of times the indoor air volume is completely exchanged with outdoor air in a given period of time.

(b) The studies are described on p. 32 of the BPA 1984 Conservation Sourcebook.

(c) Final Environmental Impact Statement for Expanded BPA Residential Weatherization Program, DOE/EIS 0095F, September 1984.

(d) BPA, "tome Weatherization and Indoor Air Pollutants," DOE/BP-310, September 1984. 
HUD also has focused on the IAQ issues and has several new regulations addressing it as part of its MHCSS. The regulations are principally directed at formaldehyde. The HUD ambient indoor formaldehyde target level chosen to provide reasonable protection to manufactured home occupants is 0.4 parts per million $(\mathrm{ppm})$. (a) Plywood materials used inside homes shall not emit formaldehyde in excess of $0.2 \mathrm{ppm}$. (b) Particleboard materials shall not emit forma?dehyde in excess of $0.3 \mathrm{ppm}$. (c) In both cases measurements are to be made according to an air chamber test method specified by HIJD. (d) Plywood and particleboard materials containing formaldehyde are to be certified by a nationally recognized testing laboratory. (e) There are no comparable federai regulations for formaldehyde in site built homes.

The MHCSS also contain minimum ventilation requirements. (f) One of the requirements is that each room must have an area of unobstructed ventilation that is at least $4 \%$ as large as the room floor area. Manufacturers are also required to offer consumers at least one of the following optional ventilation features: 1) a passive ventilation system, 2) a mechanical ventilation system, 3) a combination passive/mechanical system, or 4) a fresh air inlet capable of providing at least 25 cubic feet of air per minute. (g) Additionally, a ventilation improvement information sheet covering the options must be provided to consumers. (h) Finaliy, manufacturers must place in each completed home a health notice on formaldehyde emissions that is prominently displayed in the kitchen. The text of the notice is set by HUD. (i) The notice specificaliy alerts consumers to the fact that "reduced ventilation from energy efficiency standards may allow formaldehyde and other contaminants to accumulate in the indoor air." State and local regulations inconsistent with the IAQ provisions in the MHCSS are preempted (see Section 1.0).

\footnotetext{
(a) 49 Federal Register 31998, August 9, 1984.

(b) 24 CFR 3280.208(a) (1).

(c) 24 CFR $3280.308(a)(2)$.

(d) 24 CFR 3280.406 .

(e) 24 CFR 3280.308(b).

(f) 24 CFR 3280.103 .

(g) 24 CFR $3280.710(\mathrm{~g})$.

(h) 24 CFR 3280.710 (g)(3).

(i) 24 CFR 3280.309 .
} 
Formaldehyde levels in manufactured homes located in Washington State and associated health concerns of occupants have been investigated by Breysse. (a) Breysse sampled 430 manufactured homes for formaldehyde. A11 measurements were taken on homes where occupants had experienced adverse health symptoms. Breysse found that formaldehyde levels in manufactured homes were about 10 times higher than in site buit homes containing urea formaldehyde foam insulation. He also found that the formaldehyde level found in about $1 / 4$ of the measurements inside manufactured homes exceeded $0.4 \mathrm{ppm}$, the new HUD target ambient level. Breysse found that significant percentages of the manufactured home adult occupants complained of adverse health impacts including skin rash $(4 \%)$, nausea $(9 \%)$, headache $(24 \%)$, memory lapse $(29 \%)$, and irritation (63\%). These percentages did not differ substantially from corresponding symptoms of adult occupants of site-built homes with urea formaldehyde foam insulation even though the ambient formaldehyde levels were lower in site-built homes.

One of the leading court cases on health injury attributed to formaldehyde present in a manufactured home is a Hashington State case. (b) The plaintiff experienced eye and throat irritation and asthma attacks after purchasing a new manufactured home in 1977. The plaintiff's allergist testified that the asthma was caused by exposure to formaldehyde fumes in the home. The trial jury awarded $\$ 566,500$ in damages to the plaintiff for her injuries. The award was upheld by the Washington State Supreme Court.

No survey information on the attitude of consumers toward IAQ in manufactured homes was found for this study. One can predict, however, that concerns will be enhanced by the health notice on formaldehyde emissions that HUD now requires to be placed in manufactured homes. Future survey work on the attitudes and concerns of potential and existing manufactured home owners could provide valuable information to aid the design of programs to improve the energy efficiency of manufactured homes. A 1984 telephone survey of 603 Oregon

\footnotetext{
(a) Peter A. Breysse, University of Washington, "Formaldehyde Levels and Accompanying Symptoms Associated with Individuals Residing in Over 1000 Conventional and Mobile Homes in the State of Hashington," Proceedings of the 3rd International Conference on Indoor Air Quality and CTimate, Stockholm, Sweden, August 1984, vol. 3, p. 403.

(b) Tideman v. Fleetwood Homes of Washington, 102 Wn2d 334 (1984).
} 
residents in all housing types for the Oregon Department of Energy did address the IAQ issue. (a) Respondents were given 4 possible reasons for not taking home energy conservation actions. Fifteen percent of the respondents indicated that concern about having sufficient fresh air was a reason for not making improvements. Of this $15 \%$, about $1 / 2$ of the respondents were concerned about the health impacts of adverse IAQ.

(a) H. M. Berg, P. K. Bodenroeder, Survey Research Center, Oregon State University, Attitudes, Opinions, and Concerns About Energy: A Survey of Oregon Residents, p. 10, May 1984. 


\section{DISTR IBUT ION}

No. of

Copies

OFFSITE

20 Steve Onisko

Ronneville Power Administration

P.0. Box 36?.1

Portland, OR 97208

10 Jean Boulin

U.S. Department of Energy

Forrestal Building, GH-068

1000 Independence Avenue, S.W. Washington, D.C.

5 John Rivera

9915 Connecticut Ave.

Kensington, MO 20895

Ted Rauh

California Energy Commission

1516 9th Street

Sacramento, CA 95814

David Conover

NCSBCS

481 Cariisle Drive

Hernion, VA 2?D70

Frank Walter

Manufactured Housing Institute

1745 Jefferson Davis Highway

Arlington, $V A$ 22.202

3 Tom Eckman

Northwest Power Planning Council

850 SW Broadway, Suite 1100

Portland, OR 97205

Ernie Bonner

Bonneville Power Administration

P.0. Box 3621

Portland, $\cap R \quad 97208$
No. of

Copies

Mike Warwick

Ronneville Power Administration

P.0. Box 3621

Portland, OR 97208

30

DOE Technical Information Center

Rick Erickson

Marketing/Sales Manager

Burlington homes of New

England, Inc.

P. 0 . Box 263

Route 26

0xford, ME 04270

Warren Davis

2301 Fast 4th Street

P.D. Box 530

Marshfield, WI 54449

Hoit Blongren

National Manufactured Housing

Federation

1015 15th Street N.W.

Suite 1240

Washington, D.C.

Carol Entrekin

Florida Power and Light Company

P.0. Box 0?.9100

Miami, FL 33102

Jim Roth

New York State Electric and Gas

4500 Destal Parkway East

Binghamton, NY 13903 
No. of

Copies

4 Don Schultz

Caifornia Energy Commission

1516 9th Street

Sacramento, CA 95814

ONSITE

DOE Richland Operations Office

D. R. Segna

46 Pacific Northwest Laboratory

A. D. Lee (10)

Z. T. Taylor
No. of

Copies

Pacific Northwest Laboratory (contd)

B. L. Mohler (10)

P. L. Hendrickson (10)

R. C. Adams

R. G. Rivera

W. B. Ashton

J. M. Fang

Publishing Coordination (2)

Technical Information (5)

$\mathrm{MH}$ 